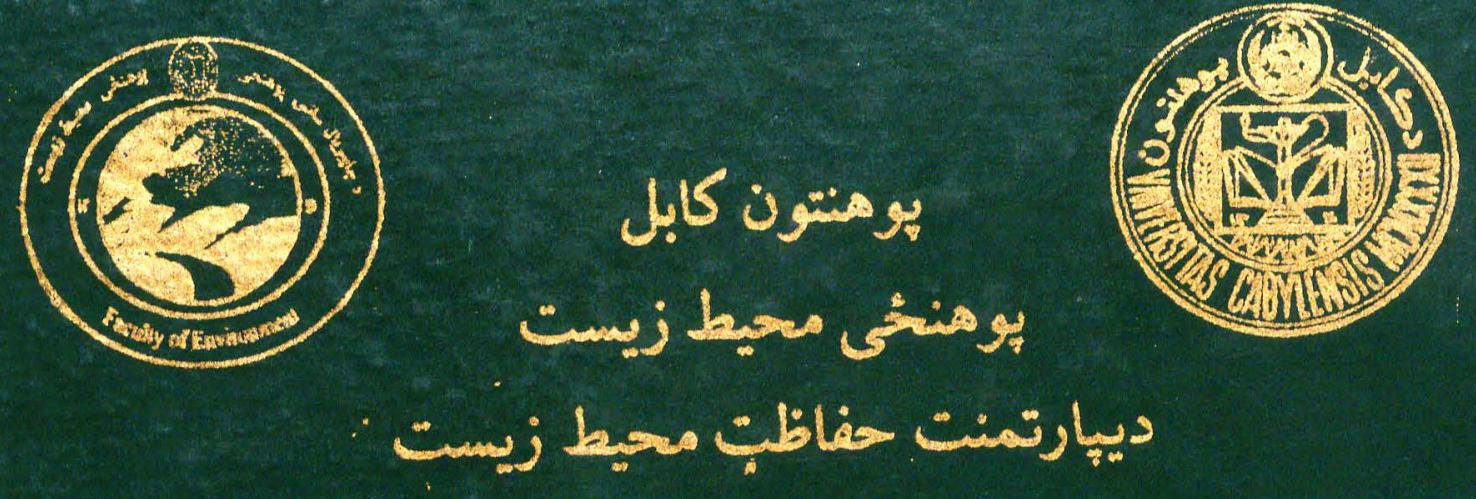

بورسي وضعيت هفظ الصحها محيطى شهو كابل

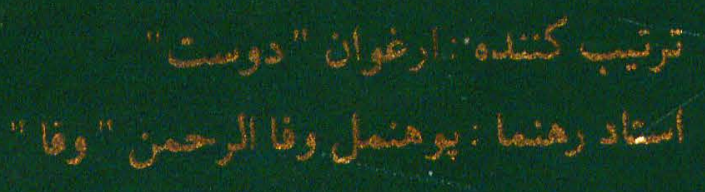




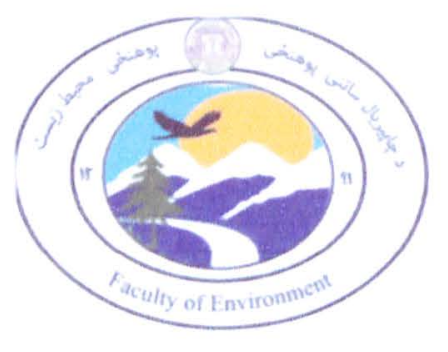

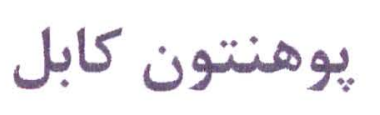

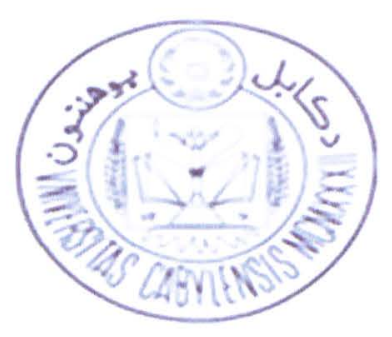

يوهنحى محيط زيست

ديبار تمنت حفاظت محيط زيست

بررسى وضعيت حفظ الصحه محيطى شهر كابل

$$
\text { تر تيب كننده : ارغوان "دوست " }
$$

استاد رهنما :يوهنمل وفالرحمن " وفا "

ش olrag

سال . 
<smiles></smiles> 
حفظ الصحه محيطى كه يكى از مسايل عمده و مهام در زندگى يك اجتماع ميباشد امروزه به يكى از مشكلات تبديل شده عدم دسترسى به حفظ الصحه سالم در شهر كابل به يك فرهنَ تبديل شده و حتى مسايل حفظ الصحه براى بعضى مردم بى تفاوت بود، نبود امكانات صحى، اقتصادى و عدم آكاهى مردم از اين معضله عوامل زياد است كه باعث بوجود آمدن حفظ الصحه ناسالم در شهر كابل شده است در اين مونوكراف بالاى وضعيت حفظ الصحه شهر كابل، امراض كه از سبب آن بوجود آمده و عوامل آن بحث شده است. سياس و ستايش مرخداى جل و جلاله قدرت او در جهره روز روشن تابان است و دروازه هاى علم را بر ما گشوهه و عمرى و فرصتى عطا نموده تا بدان بنده ضعيف خويش را در طريق علم و معرفت بيازمايد، خداوند منان را سياس گذارم كه توفيق ذات حديث شان توانايى آنرا حاصل نمودم تا يايان نامه تحصيلى ام را در مورد حفظ الصحه شهر كابل ترتيب نمايِيم در باره موضوع معلومات با كمى و كاستى از مراجع معتبر حاصل نموده ام در اين پايان نامه در مورد حفظ الصحه شهر كابل و عوامل به وجود آورنده امراض تحقيق صورت گرفته حفظ الصحه يكى از موضوعات مهم و اساس در يك جامعه ميباشد كه در شهر كابل مردم و اجتماع به وسايل مكمل حفظ الصحه دسترسى ندارد و عدم دسترسى به آب آشاميدنى صحى كافى، عدم مراعات حفظ الصحه فردى و اجتماعى، ازدحام نفوس بيش از حد در شهر كابل و سطح پايين تعليمات صحى مردم از جمله مسائل اند كه باعث شيوع امراض ميگر دد. از استاد گراميمم جناب يوهنمل وفا الرحمن (وفا) بسيار سياسگذارم خرا كه بدون راهنمايَّى هاى ايشان تامين خايان نامه بسيار مشكل مينمود به پاس عاطفه سرشار و گرماى اميد بخش وجودشان در اين سردترين روزَاران بهترين خشتيبان است به یاس محبت هاى بى دريغ شان كه هركز فروكش نميكند. باحترام ارغوان دوست 


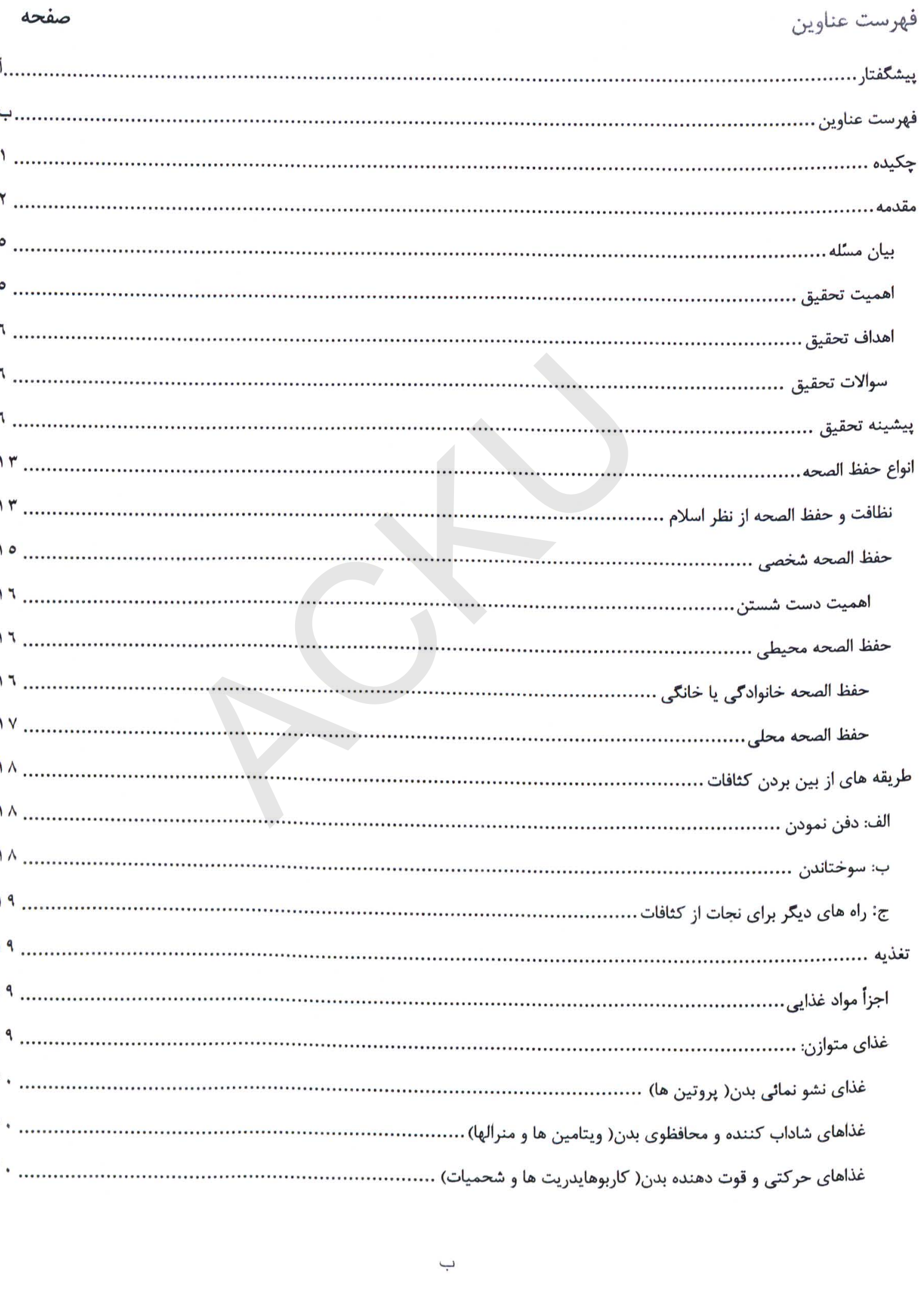


ri $r \varepsilon$

$\varepsilon$.

21 $\{r$ $\& 4$ منبع عمده آب اشاميدنى، شست و شو، بخت و يز و دكر موارد استفاده ... 
$\leqslant r$

$\{\leqslant$
مالكيت مواشى و طيور ... نوع سهولت تشناب .. كمبود آب آشاميدنى صحى شهر كابل آبهاى آشاميدنى كه در كابل صحت شهروندان را تهديد ميكند ذيلاً ذكر ميكردد .. يروزه اى آبرسانى شهر كابل كه تا حال موجود بوده كه از فرسودكى نيمه فعاليت دارند.

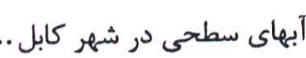
زون بندى مديريت آبهاى سطحى در كابل آبهاى زيرزمينى شهر كابل.

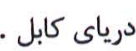
حمام ها در شهر كابل عوامل آلوده شدن آب هاى زير زمينى. شيوع امراض ناشى از آب غير صحى... زباله ها در شهر كابل. تشناب ها در شهر كابل . - مابل ينجاه درصد آلودكى هواى كابل از فاضلاب انسانى است ضعف اخلاق و معضل فرهنكى. فروش غذاهاى كنار جاده در شهر كابل .. فروش غذاهاى غير صحى در مقابل مكاتب .. سلمانى هاى روى سرى در شهر كابل ..

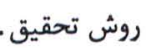
يافته هاى تحقيق . ارقام ارايه شده توسط شفاخانه ها در باره اسهالات در شهر كابل ... واكسين سك ديوانه ارقام ارايه شده امراض توسط كلنيك هاى شهر كابل سال هوبr| تحليل برسشنامه . نتيجه كيرى .

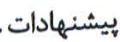
منابع و ماخذ 
كابل با يكتعداد مسايل عمده مربوط به صحت محيطى، مانند آب آشاميدنى غير صحى؛ تسهيلات نا كافى حفظ الصحه؛ سيستم فاضلاب و آبرسانى؛ شكل نادرست تنظيم كثافات جامد و خطرناك؛ آلودگى كيمياوى؛ كيفيت پايين هوا و حمل و نقل غير صحى مواد غذائى در تمام مراحل تهيه و تدارك، ذخيره و انتقال وخيم تر شدن وضعيت آن بخاطر روش هاى نامناسب حفظ الصحه، مواجه ميباشد. حفظ الصحه يكى از موارد مهرم و اساسى در زندكى يكى اجتماع ميباشد كه به همه يى ابعاد زندكَى انسان ارتباط محكم دارد. حفظ الصحه شهر كابل در حال حاضر حالت خرابى قرار دارد، در شهر كابل مردم به دليل عدم آَاهى مردم،و بى توجهى دولت، اقتصاد يايين مردم، عدم موجوديت امكانات لازم از حفظ الصحه خراب برخوردار است. در مونوكراف كه من نوشته ام در باره حفظ الصحه شهر كابل معلومات كوتاه و مفصل ارايَّه شده است آب آشاميدنى، آبهاى سطحى، آبهاى زير زمينى، عوامل آلوده شدن آبها، تشنابهاى شهر كابل امراض كه از عدم رعايت حفظ الصحه بوجود ميايد و غذاهاى كنار جاده ا جمله مسايل است كه در اين مونوكراف بالاى آن بحث شده است. هدف من از نوشتن اين مونوگراف دريافت و بررسى حفظ الصحه محيطى در شهر كابل و بررسى امراض بوجود آمده از آن ميباشد. روش راكه من در نوشتن و آماده كردن اين مونوكر اف استفاده نموده ام كتابخانه يى، يرسشناهه، مصاحبه ها و كَزارشات ميباشد. از زئشنامه كه من آماده نموده ام براى صد نفر از مردم بوده كة از ساحات و مناطق مختلف شهر كابل اشتراى داشتن دريافتم كه در كل حفظ الصحه در شهر كابل خوب نبوده مردم به آبهاى صحى دسترسى نداشته، أبها باعث امراض خون ملاريا، اسمالات و يِحش شده همجنان ارقامى را بدست آورده ام كه ليست امراض مراجعه شده در شفاخانه هاى شهر كابل ميباشد همجنان مصاحبه ها با داكتران صورت كرفته كه در باره امراض معلومات داده است 
محيط زيست پاك و سالم، از زيرمجموعه هاى جقوق بشر و از حقوق شهروندى مردم بوده و دولت ها مكلف اند كه اين مطلوب را براى شهروندان فراهم سازد. از سوى ديخر محيط زيست سالمم از نياز هاى اساسى درحيات بشرى است كه در فقدان آن، زندگى انسانها با انواع مختلفى ازمشكلات ونا بسامانى ها مواجه خواهد بود. زندگى هر فرد بسته به نوع محيطى كه درآن زيست مى كند، جدا ازشرايط اجتماعى و فرهنكَى آن، ازوضعيت اقليمى و طبيعى اش نيز متاثرمى شود. كارشناسان براى تشخيص وتعيين حد اوسط عمر در يك كشور، تاثيرات محيط زيستى را به عنوان متغيراساسى در نظر كرفته و معتقداند كه در مرك و مير مردمان شرايط زيستى نقش اساسى را دارا مى باشد. اين واقعيتى است كه به عنوان يك اصل بديهى هيج كسى نمى تواند آن را ناديده كرفته و يا تاثير محيط زيست بر جسم و روان انسان را احساس نكند.

با اين حال، مشكلات محيطى وآلودَى هاى آن ازخالش هاى جدى براى حيات آينده بشر بوده وبا رشد روزافزون اين مشكلات، گرفتارى هاى زيادى نيزبراى انسانها خلق مى شود. تغييرات اقليمى، افزايش ذرات سمى درهواو رشد سرسام آور امر اض گَوناًَون، ازعمده مشكلاتى است كه زندَى آينده بشر را تحت شعاع خود قرار داده وسالانه هزاران انسان قربانى آلودَى هاى محيطى وكمبود هواى ياك براى تنفس مى شوند. مشكلات زيست محيطى به عنوان يك يديده فراگير در تمامى كشورهاى دنيا به نحوى وجود داشته وهيج كشورى نيست كه ازتهديدات اين يديده كشنده مصئون باشد، اما ميزان اين تهديدات ومشكلات ازكشورى تا كشورديخرمتفاوت بوده و گونه هاى بر خورد با آن نيز بستَى مستقيهم به توان كشورها دارد. آلودَى محيط زيست يك مشكل جهانى بوده و بيش از هر خيز تدبير مشترى تمامى كشورهاى جهان در سطح كل را مى طلبد. هر جند اين موضوع يكى از مباحث جدى و اساسى در سياست جهانى مبدل كرديده و تاكنون رزيمم هاى مختلف حقوقى و كنوانسيون هاى زياد در اين خصوص ميان كشورها شكل گرفته است؛ اما اين مساله به لحاظ اينكه يك موضوع جديد مى باشد، هنوز نتوانسته مانند ساير مسايل و موضوعات حياتى بين المللى جا افتاده و تدابير و مقررات 
مبارزه با آن، به عرف الزام آور بين المللى در كنار ساير موضوعات سياسى و امنيتى جهان بدل گردد. با وجود اينكه محيط زيست دارد به تهديد اصلى و جدى عليه كره ما تبديل مى كردد، اما هنوز هم اين موضوع در سياست كشورها اولويت دوم بوده و كشورها در صورت تصادم منافع، به راحتى جشم بر معضله محيط زيست بسته و اجازه مى دهند در راستاى تامين منافع ملى، محيط زيست آسيب بيبينند. درين ميان افغانستان ازجمله كشورهايى است كه ميزان آلودگى هوا ومحيط زيست درآن به شكل نكَران كننده يى روبه گَسترش بوده وبراساس آمارهاى موجود روزانه ده ها نفر بنا به آلوده گَى دحيط زيست به امراض تنفسى و ساير امراض كَرفتار مى شوند.كابل بايتخت كشور شهرى است كه آلودى آن به كونه سرسام آور و نكَران كننده اي بالا رفته و اين در حالى است كه هيجَّونه تدبير و سازوكارى مبارزاتى با اين يديده از سوى دولت وجود ندارد. روزانه ميليون ها ذره سمى و مكروبى از كو خه ها و يس كوخه هاى كابل برخواسته و در كنار دود و گرد دخاك بر فضاى تنفسى شهروندان كابل مستولى گَرديده و به هواى تنفسى اين مردم تبديل مى گر دد. هواى كابل دربسيارى اوقات به حدى آلوده با دود وخاى و ديخًرعوامل آلوده كنيده است كه اكثرا درهوا جترتاريك ومكدرى را برفضاى شهربه وجود مى آورد و در زمين هم خاك وتعفن ناشى ازمواد مختلف آلوده كننده، افراد را كرفتتارمشكلات عديده يى مى سازد. در جنين وضعى امراض مختلف جسمى و روانى ايجاد كردديده و زندكى مردم را تهديد مى كند. آلودىى هواى شهرهاى افنانستان به خصوص كابل عمدتا ناشى از مصرف بى رويه مواد نفتى در موترها و وسايط نقليه، خرابى جاده ها كه دربسيارى موارد باعث ايجاد كرد و خاى مى شود، نبود ساحات سبز كه براى تصفيه هوا وجلوكيرى از بروز گرد وخاى نهايت موثراست، فقدان سيستم كاناليزاسيون و سايرامكانات رفاهى درجامعه و درنهايت بى توجهى مردم براى نكَهدارى محيط زيست بوده وعلى رغهم نغَرانى هاى شديد از رشد روزافزون آلوده كى ها، بازهم توجه جندانى به اين معضل نمى شود.

در كابل تنها هوا آلوده نيست، بلكه آلودگى صوتى يكى ديكًر از مسايل و معضلات اجتماعى خطرناكى مى باشد كه نسبتا كمتر از آن سخن كَفته مى شود. با گشت و گذار در سطح شهر و سرى هاى كابل، به زودى متوجه اين 
امر مى شويد. شهروندان كابل، خصوصا كاسبان و بازاريان اندى ترين هنجار هاى شهرنشينى را در نظر نغرفته و ملاحظه سايرشهروندان و مردم را نسبت به امنيت و آرامش صوتى در نظر نمى كيرند. موسيقى هاى كه از بلند كوهايى قوى بر فراز دروازه هاى هوتل ها، رستورانت ها، كست فروشى ها و خدمات ثبت و صوت در شهر كابل بلند مى شود، جنان طنين منزجر كننده اى را خلق مى كند كه تحملش براى دقيقه اي هم براى عابرين هم دشوار مى باشد، جه رسد به آنانيكه در اطراف آن زندگى كرده و يا روز كامل را به منظور كار آنجا سيرى مى سى نمايند. يا مثلا موتر هاى ملى بس و وسايط شخصى هيجحَّونه احتر امى به آرامش مردم و محلات خاصى خون شفاخانه ها و مدارس و دانشًاه ها نداشته و با هارن هاى بى موقع و اغلبا بلند، آرامش و روان صدها انسان را كه. در اطراف آن هستند، به هم مى زنند. اين در حالى است كه دولت هيجحَونه مقر راتى در اين خصوص نداشته و يا حداقل در اين مورد بر رفتار و كردار مردم كنترل ندارند. در كنار امنيت جسمى، نظهم و قانون، تامين امنيت و آرامش روحى و روانى مردم و برقرارى نظم جمعى در شهر از مسئوليت ها و وظايف اصلى دولت بوده و دولت مكلف است تا از آرامش روحى و روانى مردم ياسارى نمايد. 
شهر كابل با يكتعداد مسايل عمده مربوط به صحت محيطى، مانند آب آشاميدنى غير صحى؛ تسهيلات نا كافى حفظ الصحه؛ سيستم فاضلاب و آبر سانى؛ شكل نادرست تنظيم كثافات جامد و خطرناك؛؛ آلودَى كيمياوى؛ كيفيت يايين هوا و حمل و نقل غير صحى مواد غذائى در تمام مراحل تهيه و تدارك، ذخيره و انتقال وخيم تر شدن وضعيت آن بخاطر روش هاى نامناسب حفظ الصحه، مواجه ميباشد. در عصر امروزى حفظ الصحه مشكلات زيادى را براى مردم به بار آورده و دليل اصلى آن عدم آكاهى مردم از اين

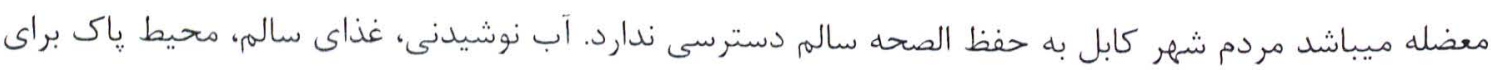
ييشرفت نيروى يك جامعه لازمى ميباشد در شهر كابل كه از ير نفوس ترين مراكز دنيا ميباشد نتوانسته محيط ياك و سالم داشته باشد. هدف از اين تحقيق دريافت حالت يا وضعيت موجود حفظ الصحه در شهر كابل و همجنان بررسى امراض بوجود آمده از آن ميباشد. اهميت تحقيق به علت زياد شدن آلودَى در شهر كابل كه در اين اواخر دوضعيت حفظ الصحه در شهر كابل بسيار وخيهم و قابل تشويش ميباشد خواستم با انجام اين تحقيق يك رهنمايى براى آكاه ساختن در باره حفظ الصحه شهر كابل و امراض بوجود آمده به افراد جامعه بسازم تا از اين طريق به راه هاى حل آن دست يابيه. آب، مراعات اصول

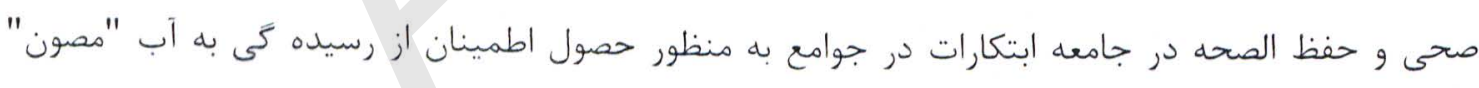
مشتمل اند بر: اعمار و بازسازى خاه ها و اعمار سيستهم هاى آب ذريعه پايب هاى كوجى در روستاها و همجنان ايجاد ميكانيزم هاى كيفيت آب و ترويج استفاده از روش هاى درمان يا تصفيه آب در سطح خانه. ترويج اعمار و استفاده از تسهيلات صحى در سطح خانواده همراه با بلند بردن سطح آكَاهى اطفال و خانواده ها در رابطه به اهميت شتن دستها براى صحت خوب و جلوكيرى از شيوع امراض، يك فعاليت عمده ديكًر است 
اهداف تحقيق

$$
\text { بربر بر برسى وضعيت كنونى حفظ الصحه محيطى در شهر كابل. }
$$

سوالات تحقيق

• مردم شهر كابل تا خه انداره به حفظ الصحه دسترسى دارند؟

$$
\text { مردم به كدام امراض بيشتر مبتلا ميشود؟ }
$$

ييشينه تحقيق

موضوع را كه بالاى آن تحقيق نموده ام حفظ الصحه شهر كابل ميباشد كه قبل از من هيج كس بالاى آن تحقيق ننموده است جون اين موضوع كاملا جديد ميباشد اما در اين قسمت از طرف حكومت براى مردم بشكل آكًاهى دهى كاراهاى صورت كرفته است .

بعضى كتابهاى كه حفظ الصحه كه در هندوستان نوشته شده است: The politics of sanitation در سال 11 • ب توسط susan.E. chaplin به نشر رسيده است Sanitation law and policy توسط philippe ullet, lovleenbhullar به نشر رسيده است. lal Sanitation and health in rural دbahadur shastri ولايت كابل پايتخت افغانستان است و اين شهر در زون مركزى موقعيت داشته، مقر دولت بوده واكثريت موسسات سكتور تجارت داران موقعيت داشته در مسير تجارت منطقوى بين ياكستان و آسيايى ميانه قرار دارد. 


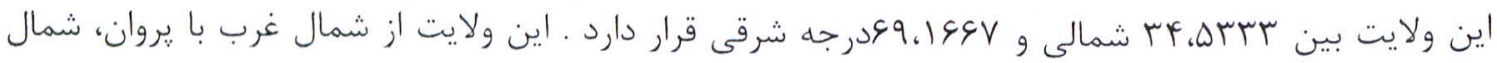
شرق با كاييسا، از طرف شرق با لغمان، جنوب شرق با ننحرهار، از طرف جنوب با لوكر و از طرف غرب با وردى هم سرحد است. (سلطان محمد . (IF) كابل در ارتفاع حدود .11 متر از سطح بحر واقع بوده، كه آنرا يكى از مرتفع ترين پايتخت هاى دنيا ساخته و منجمنت مركزاقتصادى و فرهنكَى افغانستان شناخته شده. مساحت مجموعى اين ولايت FATY كيلومتر مربع است كه از ع، · فيصد ساحه افغانستان نمايندگى ميكند علاوه بر شهر كابل اينولايت داراى f اولاسوالى ديخر نيز ميباشد يعنى: يغمان جهار آسياب، بكر امى،ده سبز، شكر دره، موسهى، ميربجه كوت، خاى جبار، كلكان، كَلدره، فرزه، استالف، قره باغ و سروبى. دو نبات عمده كه در اين ولايت كشت ميشود عبارت از كَندم وكجالو ميباشد. كَندم صرفا در داخل به مصرف ميرسد محصول آن به اندازهاى نيست كه تقاضاى محلى را مرفوع بسازد كاهش سالانه در محصول كَندم همهنان نتيجه تبديل شدن زمينهاى قابل آبيارى به ساحات باغدارى و كشت سبزيجات، عمدتا بخاطر اين كه اين محصولات در بازارهاى داخلى و صادراتى به قيمت هاى بلندتر به فروش ميرسد، ميباشد. عمده ترين فصل برداشت محصول كَندم بين ماه هاى اسد و سنبله و براى سبزيجات ميزان و سنبله است. اين ولايت به مقياس وسيع در زون يك محصولى قرار داشته بنابر درجه حرارت و اقلم قسما محصول دومى كشت ميشود. سيب يك محصول وادى شمالى است كه در بازار هاى محلى به فروش ميرسد. فرصت هاى جهت توسعه سيب در يغمان و شكردره كه در آنجا شرايط مناسب است وجود دارد. شهر كابل اعلباً • . ده سال قبل به موقعيت فعلى اش از يك دهكده بيش نبود؛ ابتدائى ترين دهكده زراعتى آن درنشيبى هاى آفتاب رخ كوه آسمايى بين ده افنانان موجوده و درياى كابل با خانه هاى كَلى اعمار شده بود. با كذشت زمان طى حكومت كابل شاهيان بالاحصار كابل با ديوار هاى اطراف آن بالاى كوه شير دروازه و آسمايى كابل انكشاف مزيد يافت و به حيث يك شهر دفاعى و استرازيكى، مركز سياسى حكومت كابل شاهيان را تشكيل 
از آن به بعد اين شهر تاريخى بنابر ارزش هاى تجارتى دفاعى و سياسى بيشتر عطف توجه كرد و به صورت تدريجى راه انكشاف مثبت را دنبال كرد و طى قرون و اعصار به محدوده فعلى اش نايل آمد. وضع جيولوزيكى كابل در مقياس شهر و ولايت كابل روى ساختار هاى مشابه و همكَون استوار است. زيرا اثرات جيولوزيكى ساحه وسيع را احتوا مى كند كه اقلاً شامل يك حوزه نسبتاً بزرك ميباشد. ولايت كابل به شمول شهر كابل يك ميلون سال قبل تا حصه تنكى غارو، بحيره بزرگى را تشكيل مى داد و در

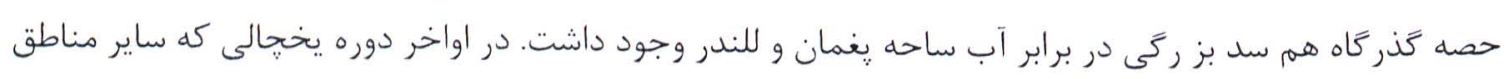
را يخجال يوشيده بود بارنده گى هاى شديد به وقوع ييوست و اين بحيره بزرى از آب مملو گرديده، رسوبات مختلف از سطح زمين آن به ضخامت ·r الى لـ متر تراكم كرد. اين بحيره بزرى از حصه تنكى غارو، مجراى خود را آهسته آهسته بيدا نمود و تا حصه ماهيبر دره خوردى را تدريجاً به عمق موجوده حفر و تخريبات فرسايش

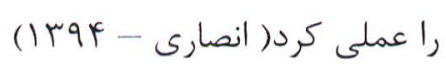

از مجراى تنكَى غارو آب به جريان آفتاده در نتيجه بحيره يى كه در ساحه ولايت كابل بود به تدريج يائين امده تا آنكه به رسوبات تحتانى قاعده بحيره رسيد و اين رسوبات در ساحات مختلف توام با مجراى درياى للندر، لوكر، درياجه يغمان ( جمجها مست ) توسط جريان مجموعى آب بريده شد در جا هاى كه مجراى آب رسوبات نرم راز بين بورده زمين هموار و يا بستر دريا هاى فعلى و مجراى سيلاب ها موسمى را تشكيل داد. جا هاى كه رسوبات سخت بود از سطح زمين بلند ترمانده تِه هاى مختلف را به وجود آورده از قبيل تيه مرنجانا، تِه شهر آرا (بركى)، تيه قلعه بلند، كلوله پشته، تيه بى بى مهرو و تيه هاى نزديك يلجرخى اند كه هر كاه اكربه دقت ديده شود، رأس اين تِه ها همه در يك ارتفاع اند و رسوبات دريايى و يخحالى به صورت مشابه طبقات موازى متشكل از كَل رُس، جغله هاى دريايى و يخجالى در آنها به صورت مشابه بوده، طبقات ريخ ها درشت يخحالى و كتله هاى مستحكم كانغًلو ميرايت ها كه با هم سمنت و فشرده شده اند، يكجا با ريخ و سنكَريز ها يكى بالاى ديكر ديده مى شود 
اقليم شهر كابل و لسوالى هاى اطراف آن در يكى رديف مشابه و همكَون قرار دارد. عوامل موثر در اقليم كابل اولتر

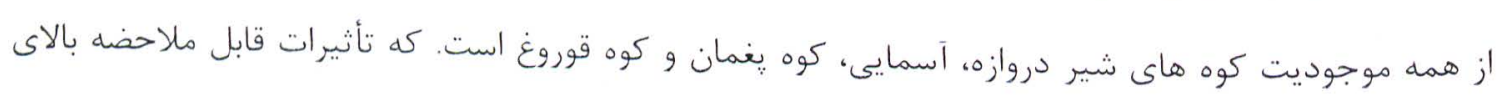

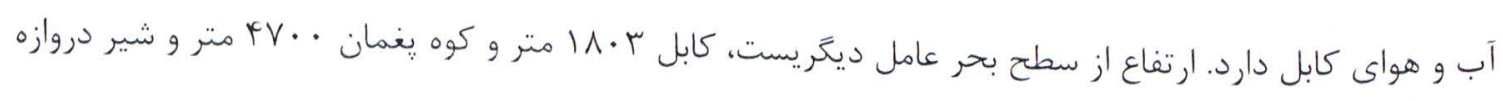

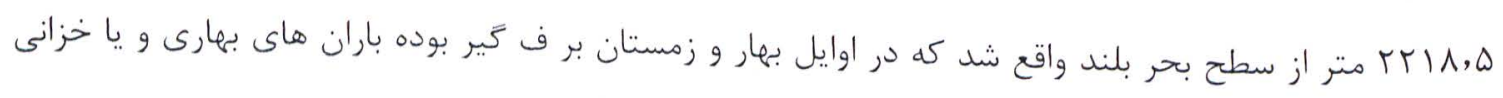
آن بالاى شهر كابل و لسوالى هاى اطراف آن اثر قابل ملاحضه دارد. وزش بادهاى زمستان كه از صفحات شمال به سمت كابل مى وزد، بخصوص باد هاى سرد سايبر يائى يا جبهه سرد ايام زمستان باعث ريزش برف و باران مى كردد. در اوايل بهار جريانات مرطوب از سمت بحيره كسيين سبب بارنده كى ها وقفه ئى در ماهاى حمل و ثور شده كه سبب تغذيه آب زيرزمين نيز مى شود به همين ترتيب در ايام تابستان هواى مرطوب خليج فارس باعث بانده كى ها موقت در ولايت كابل مى شود.

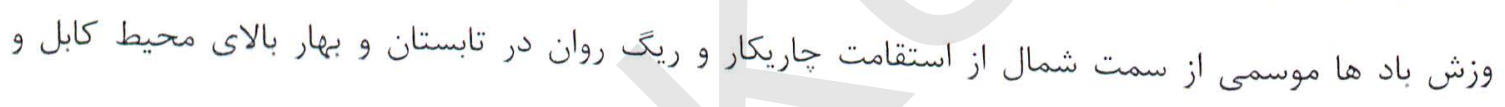
ولسوالى هاى اطراف آن تأثير زيادى دارد. حتى درختان توت در كنار سرى عمومى به طرف كابل تا حدى متمايل

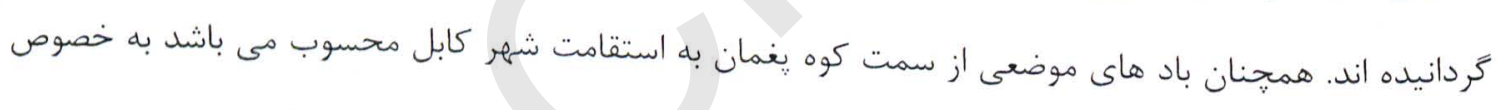

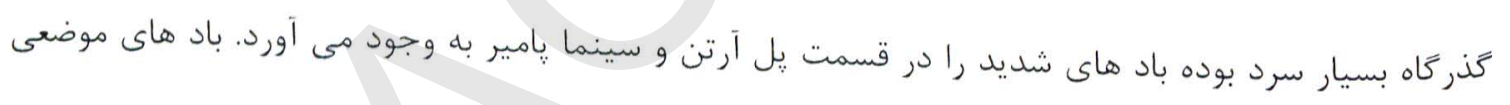

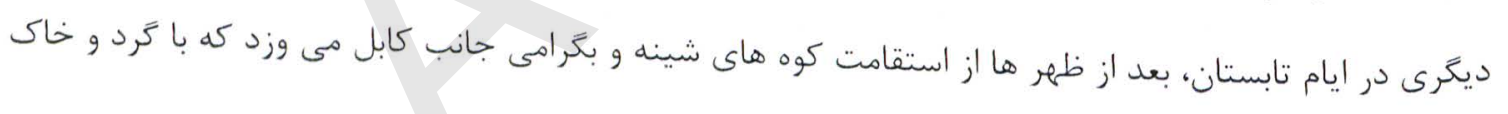

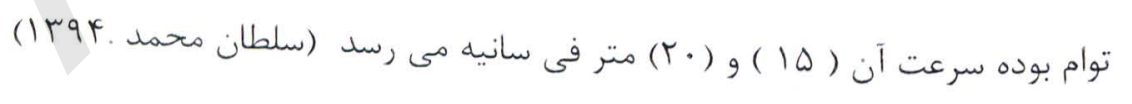


طرز استفاده شهر كابل (طرز استفاده زمين در شهر كابل): - ساحه رهايشى UL فيصد.

ـ ساحه صنعتى و مراكز عامd، ساحات سبز و سر كها \&\&, ف فيصد.

ـ ساحه كَدام ها و يار كنَّ هاى عمومى ^ فيصد. - ساحه كلتورى و سركماى حلقوى ه, ه فيصد.

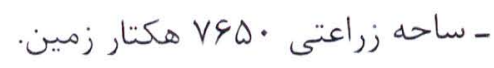
ـ قبرستان ها f, إ فيصد (معادن . . هكتار ). كه مجموعاً . • در كشور ما افنانستان شهر نشينى در اين اواخر كاملاً مشهود و به افزايش مى باشد. بعد از اين كه در سال ا .. جنَ ها تقليل يافت مهاجرت هاى سرسام آور از دهات به شهر ها بلخصوص به شهر كابل آغاز و اين افزايش عودت مهاجرين از خارج در شهر ها بيشتروبيشتر گرديده است.

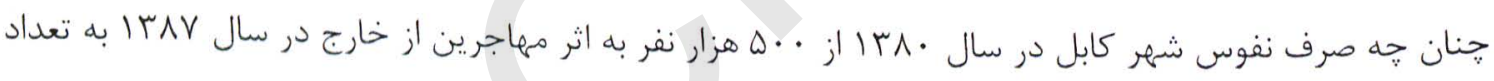
سه مليون نفر تخمين شده است و به اين اساس تا سال ها • ب نفوس شهر كابل به هفت مليون نفر افزايش يافت. جون نفوس زياد به منابع بيشتر ضرورت دارد از همين خاطر در شهر كابل منابع حون منابع آب زيرزمينى به علت افزايش نفوس و استفاده بيش از حد كاهش خواهد يافت.

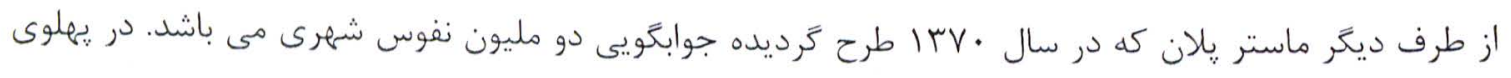
افزايش نفوس در شهر كابل به تعداد نفوس. تعداد نفوس كه در محلات يا ولسوالى ها زنده كى دارند روز به روز افزوده گرديده و دسترس به امكانات صحى هنوز محدودتر و عدم موجوديت محيط زيست مناسب، بيكارى، آلوده گى هوا، آلوده گى آب سطحى و آب زيرزمينى و ساير معضلات در شهر كابل باعث مى شود. براى حل معضله شهر نشينى ايجاب مى نمايد تا دولت تدابير منظهم و عملى رادر دهات روى دست كيرد. براى جلوكَيرى از روند سريع شهر نشينى، افزايش خدمات اجتماعى از قبيل ايجاد مراكز صحى، تهيه امكانات تعليم و تربيه، سهولت هاى 
ترانسيورتى و غيره در دهات تا اندازه از افزايش سريع شهرنشينى ميتوان جلوَّيرى گَدد ولى معضلات كه در نتيجه جنين مهاجرت هاى سيل آسا يا شهر نشينى بدون مديريت ايجاد مى كردد نمى توان از آن جلوكَيرى كرد يعنى اكَر آب آلوده شد، هوا آلوده شد بعداً اين گَونه مشكلات و معضلات بسيار به مشكل است جلوَّيرى كنيم ويا طى جندين قرن حل خواهد شد. به اساس ماستر : يلان ها كابل را به جهار منطقه ذيل تقسيم بندى مى كند: منطقه شمال غربى: حاوى (•و F9 هلتار زمين) و (•rع هزار نفوس) از طرف غرب كوه افشار، از طرف جنوب كوه آسمايى و درياى كابل، از طرف شمال سرى حلقوى و از طرف شرق درياى كابل آن را دحدود مى سازد. منطقه شمال شرقى: داراى (•l\&V هكتار زمين و • اب هزار نفوس) كه از طرف غرب به منطقه جشن، جمن حضورى و درياى كابل، از طرف شمال به درياى كابل از طرف شرق به سرى حلقوى و از طرف جنوب به تيه مرنجان محاط مى باشد.

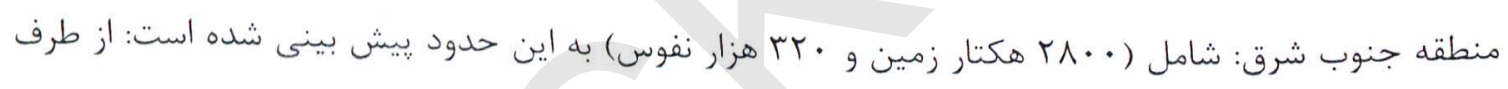
غرب كوه شير دروازه، از طرف شمال درياى كابل و تيه مرنجان، از طرف شرق و جنوب سرى حلقوى. منطقه جنوب غرب: داراى ( . VY هكتار زمين و • • هزار نفوس) به اين حدود بيش بينى شده است: از طرف غرب و جنوب به سرى حلقوى، از طرف شمال و شرق به كوه آفشار، على آباد، كوه آسمايى و كوه شير دروازه

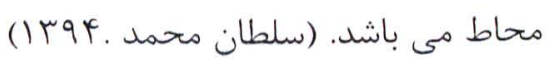




$$
\text { ولى شاروالى كابل اين جهار منطقه را به Vا ناحيه شهرى تقسيهم كرده است آن هم به شرح ذيل: }
$$

مجموعه نفوس (ارقام به هزار) تعداد خانوار ( ارقام به هزار)

شمار0 نواحى

\begin{tabular}{|c|c|c|}
\hline $1 T, \Lambda$ & VQ,Y & ناحيه اول \\
\hline $10,$. & 91,0 & ناحيه دوم \\
\hline $1 \Lambda, r$ & $11 \cdot, v$ & ناحيه سوم \\
\hline$r V, r$ & $r r \Delta, q$ & ناحيه جهارم \\
\hline$r \Delta, \Lambda$ & $r \mid \Lambda,$. & ناحيه ينجمم \\
\hline$f, i, f$ & rYI, r & ناحيه ششمم \\
\hline $4 \lambda, 1$ & $r \Lambda \Lambda, Y$ & ناحيه هفتم \\
\hline$r 4,9$ & $r r q, \wedge$ & ناحيه هشتم \\
\hline$r r, \Lambda$ & $r \cdot v, \Delta$ & ناحيه نهم \\
\hline$F, Q$ & $r \Delta F, \Delta$ & ناحيه دهمب \\
\hline$r 1,9$ & 199,1 & ناحيه يازدهم \\
\hline$\omega, V$ & $r \varphi, \varphi$ & ناحيه دوازدهمم \\
\hline$r \Lambda, r$ & $19 \Lambda, 4$ & ناحيه سيزدهم \\
\hline$r_{\Lambda}$ & $19 \cdot . r$ & ناحيه جهاردهمم \\
\hline$F r, Q$ & TVY,r & ناحيه يانزدهمم \\
\hline $19, r$ & $11 \Lambda, Y$ & ناحيه شانز دهم \\
\hline 11,4 & $v k, 1$ & ناحيه هفدهم \\
\hline
\end{tabular}


حفظ الصحه

حفظ الصحه عبارت از باك نكمهداشتن شخص و محيط جهت تامين صحت ميباشد نظافت نظافت بيانغًر حالت ياكى و ستر گى ميباشد.

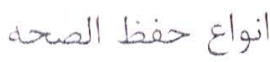
حفظ الصحه دو نوع است

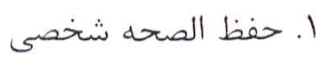
Y. حفظ الصحه محيطى

نظافت و حفظ الصححلة أز نظب اسلام فضيلت ياكيزگى

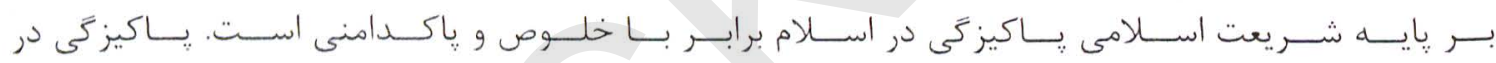

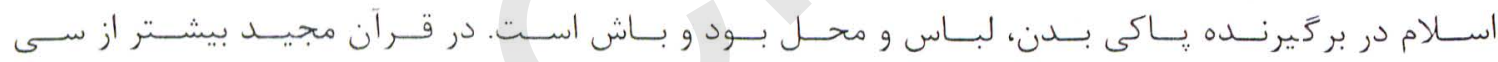

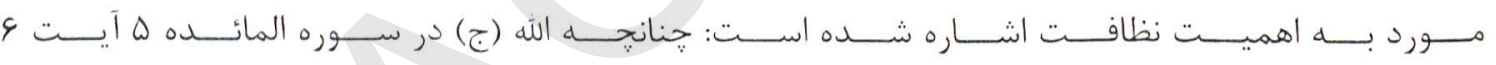
ميفرمايد: سوره ه: المائده(آيه ششم)

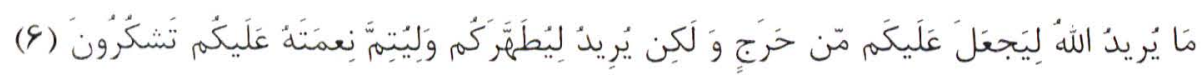

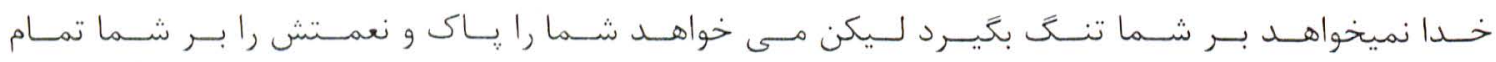
كر دانده باشد كه سياس او بداريد. 


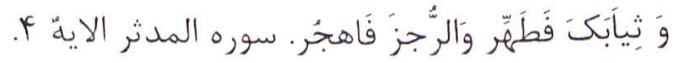

$$
\begin{aligned}
\text { احاديث شريف نباس خود را ياى كن. } &
\end{aligned}
$$

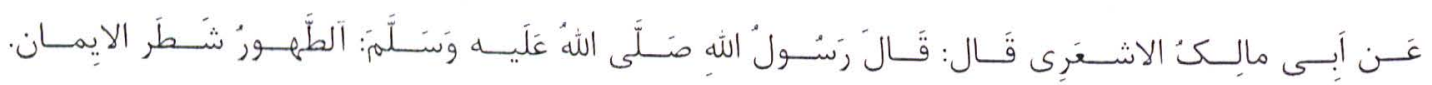

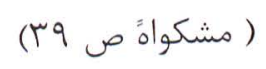

ترجمه: نظافت جز ايمان است.

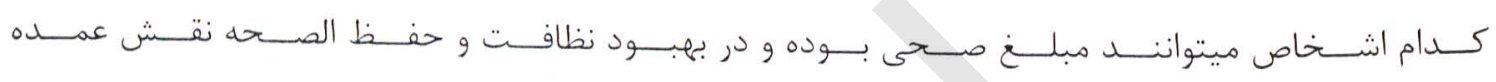
داشته باشد:

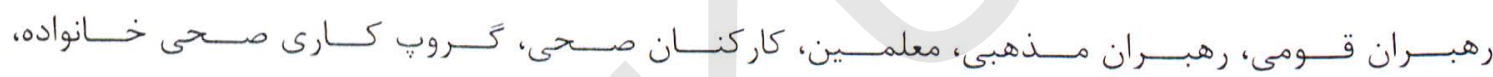

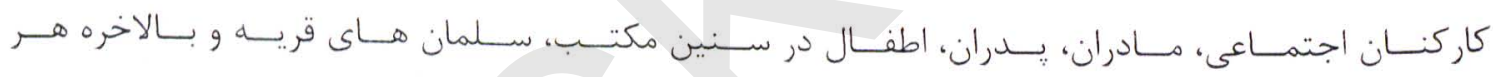

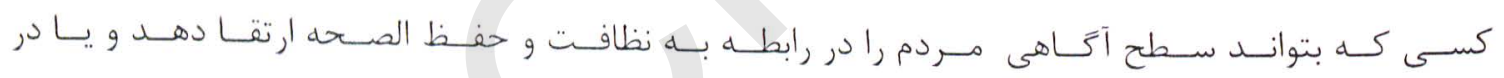
عادات مردم تغيرات مثبت را بوجود آورد، مبلغ صحى ميباشد. مبلغ صحى خوب داراى اوصاف ذيل ميباشد

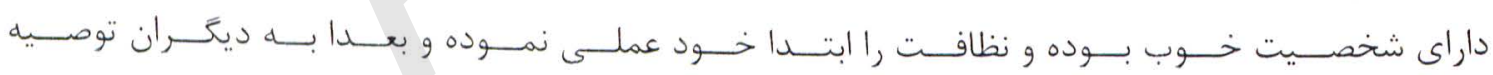
نمايد

زبان و لهجهه مردم محل را فهميده، عام فهم و ساده صحبت نمايد

با ديخران احترام داشته به سخنان آنها كَش داده و با حوصله باشد

مهارت هاى خوب و افهام و تفهيم داشته باشد (اسلام و محيط زيست . بr ب I) 
vن تعريف: حفظ الصحه شخصى عبارت از پاى نكَهداشتن تمام بدن و لباس ميباشد مانند. تكنه شستن دستها با آب پاك و صابون در اوقات( بعد از رفع حاجت، بعد از زاى كردن اطفال و شستن نك. هاى آن، بعد از تماس با تمام اشياى ناياى و حيوانات، قبل از خوردن غذا، تهيه و دادن غذا براى اطفال) كوتاه نمودن ناخون ها حد اقل هفته يكبار پاك نتحهداشتن و شانه كردن موها به صورت روزمره شستن دندانها توسط برس و يا مسواك بعد از صرف غذا

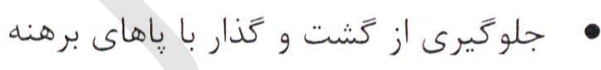

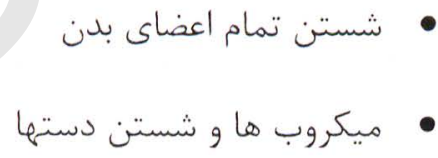

ميكروبها موجودات كوجى اند كه ما آنها را با حشم ديده نميتوانيم. ميكروبها به طريقه هاى مختلف داخل بدن انسانها كرديده و آنها را مريض ميسازد. ميكروب ها در جاهاى كثيف مانند كثافت دانى، طويله خانه، بيا الخلا ها، آبياى ايستاده، غذاى شب مانده و باسى، وغيره پِيدا مى شود.

ميكروب ها ميتواند از طريق دستهاى ملوث و نا شسته، تنفس، زخم هاى جلدى، مواد فاضله، خاك، شير خوشك، مَّس ها، آب و مواد غذايى ملوث به بدن انسانها انتقال نموده و باعث امر اض كَوناكون مى كَرد. طريقه هاى حفاظت بدن از حملات ميكروب:

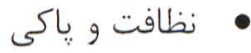

$$
\begin{aligned}
& \text { ر رزيم غذايى خوب و آب آشاميدنى صحى } \\
& \text { واكسيناسيون }
\end{aligned}
$$


اهميت دست شستن

جون صابون ميكروب را از بين ميبرد ما بايد دست هاى خود را با آب و صابون بشويهم. كروب صحى خانواده بخاطر پاى نكَهداشتن دستان خود بايد كارهاى ذيل را انجام دهند:

$$
\text { ناخن هاى خود را با ناخون گير بيخيرد }
$$

دستها، روى و نواحى سورين اطفال خويش را ٍاى نكَهدارد

ارشادات اسلامى: نوسط احاديث نبوى

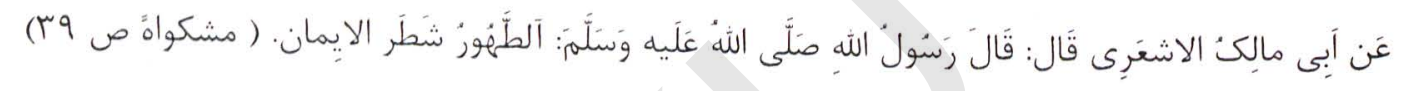
ترجمه: نظافت جز ايمان است.

خداوند(ج) نظافت و پاكى را دوست دارد. از همين سبب دين مقدس اسلام به ما امر نموده كه روزانه قسمتهاى از وجود خود را شستشو(وضو) دهيم.

حضرت محمد(ص) روزاهى جمعه قبل از اداى نماز ناخن هاى مبار كى خود را كرفته و غسل مى نمودند. (اسلام و

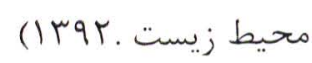

حفظ الصحه محيطى حفظ الصحه محيطى دو نوع است

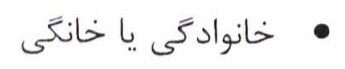

$$
\text { जos }
$$

حفظ الصحه خانوادَى يا خانكى

شامل پاكى اطاق ها،آشيزخانه ها، حويلى، داشتن بيت الخلا محفوظ و تشناب، نكمهدارى آب آشاميدنى و غذا به طور مصئون، جابجا كردن كثافات در محل مناسب، جلو گيرى از حيوانات مضر مانند موشها، حشرات وغيره. 
حفظ الصحه محلى

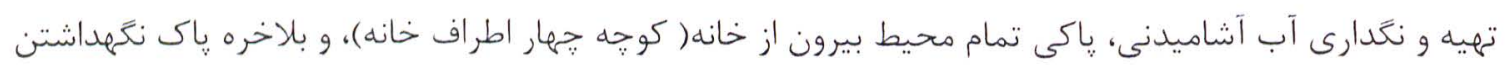
محل از هر نوع فضلات( حيوانى و انسانى)، كثافات مايع و جامد، اشيايى مضره و كنترول حشرات، خزندگان و حيوانات مشكلات كه از سبب نبودن بيت الخلا در جامعه بوجود ميايد: عده يى از مردم در جامعه ما غير مسولانه در فضاى آزاد و بيرون از خانه رفع حاجت ميكنند. عده يى هم كناراب هايشان را پاكى نتحهدارى نميكنند. بسيارى از امر اض كه مر دم و خصوصا اطفال به آن مصاب مى شوند، امراضى اند كه به وسيله مواد غايطه انسانى سرايت مى نمايند، مردم نميدانند كه اطراح بى جاى مواد غايطه سبب بوجود آمدن امراض مى كَرد يس براى از بين بردن آن اين عادت جه بايد كرد؟ ابتدا بايد مكان رفع حاجت مردم منظقه شناسايى شود.بعدا با آنها بحث و كَفتكو شود كه رفع حاجت در هر جاو بيجا خطرناك است از همين جهت لازم است تا تمام مردم از بيت الخلا استفاده نمايند. حفظ الصحه محلى يا محيط بيرون از خانه در مورد رعايت حفط الصحه محيط تمام مردم دحل مسوليت دارد تخليه و جابجا كردن مواد فاضله بيت الخلا بشكل مصوّن جابجا كردن مواد فاضله حيوانى بشكل درست دفن كردن و سوختاندن كثافات به طريقه هاى مصئون • از بين برن آبهاى ايستاده

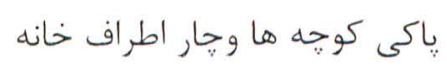


كثافاتيكه در هرخانه در نتيجه آشيزى، خوردن، پاى كردن، جاروب كردن وغيره بوجود مياًيد. اكر در محيط خانه باقى بماند بسيار خطرناك ميباشد. بايد اين كثافات روزانه از داخل و اطراف خانه دور ساخته شود.

مشكلات اساسى كه توسط كثافات بوجود مى آيد.(عثمانى. Irqr)

$$
\text { باعث كثيف شدن محيط و بوى بد مى }
$$

باعث تجمع مگَس ها و موش ها شده و سبب ملوث شدن غا و انتقال امراض مى كردد

$$
\text { وقتيكه در نزديك منابع آب باشد سبب ملوث شدن آن ميشود }
$$

اشياى بيكاره در نزديك منازل باعث زخمى شدن و ميكروبى شدن زخمى ها و امراض جلدى مى گردد.

$$
\begin{aligned}
& \text { طريقه هاى از بين برن كن كافات } \\
& \text { دفن نمودن } \\
& \text { سوختاندن } \\
& \text { الف: دفن نمودن }
\end{aligned}
$$

بيرون از محل بود باش دفن گرديده و حد اقل ·r متر دور تر از منازل رهايشى دور باشد در يك سطح پايين تر از زمين قرار داشته باشد حد اقل · · امتر از منابع آب دورتر دفن گردد بالاى كثافات حد اقل r تا r ساتنى متر خاى انداخته شود از دسترسى اطفال دور باشد.

بو: سوختاندن كثافات قابل سوخت دور از محل زندگى سوختانده شود 
ج: راه هاى ديثر براي نجات از كثافات

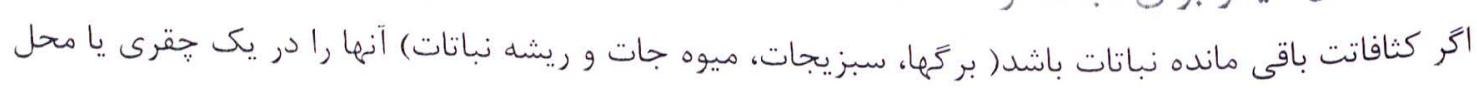
جداكًانه جابجا كنيد ( اكَر ممكن باشد آن را با خاكى مخيوط نمائيد) اين مواد به زودى به كود تبديل خواهد

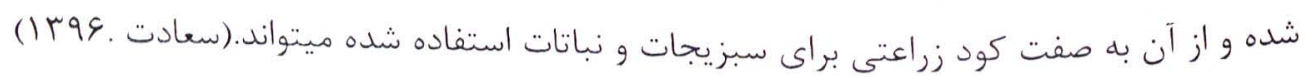
تغذيه غذا: هر ماده كه خورده و نوشيده و منبع غذايى داشته و براى بدن مفيد بوده و مضر نباشد غذا ناميده مى شود. غذا

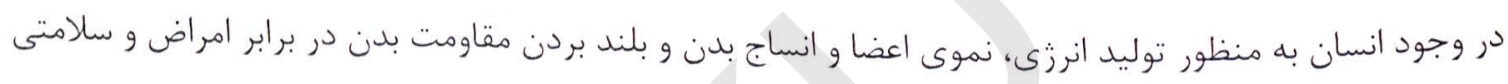

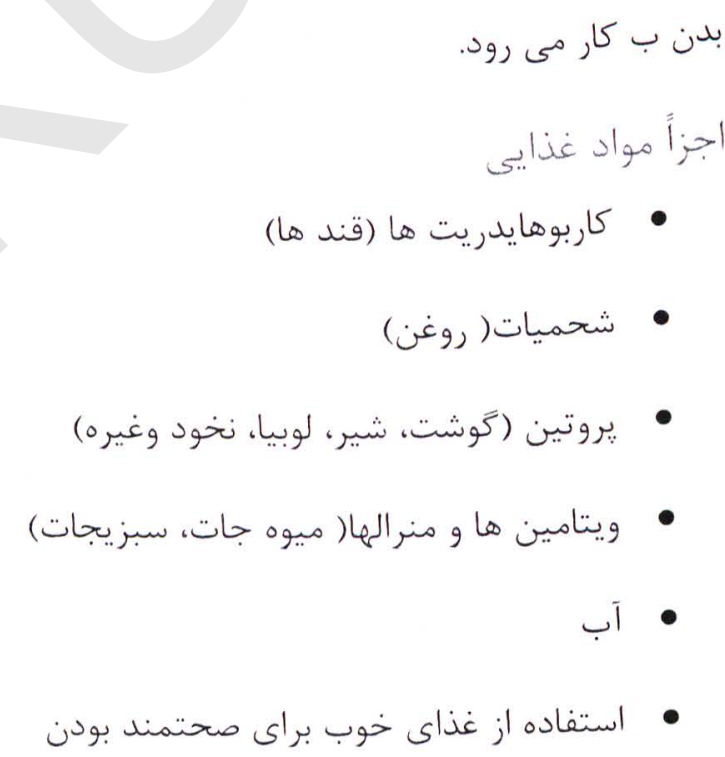

بهترين راه صحتمند ماندن مادران و اطفال خورن غذاى كافى و انواع خوب غذاها ميباشد.

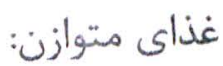

براى اينكه خانم هاى حامله و شيرده صحتمند باقى بماند بايد آنها را نظر به ديكًر افراد غذاهاى متوازن بيشتر مصرف نمايند. 


$$
\text { غذاى نشو نمائى بدن (يووتين ها) }
$$

يروتين ها در حبوبات مانند ( باقلى، لوبيا، نخود و عدس) و همجنان ميوه هاى خسته دار (خسته، پيته، بادام) و غله جات( َّندم، جوارى) و محصولات حيوانى مانند كَشت، شير، تخم مرغ، ينير، قيماق و ماهى داراى يروتين

غذاهاى شاداب كننده و محافظوى بلن (ويتامين ها و منرالها)

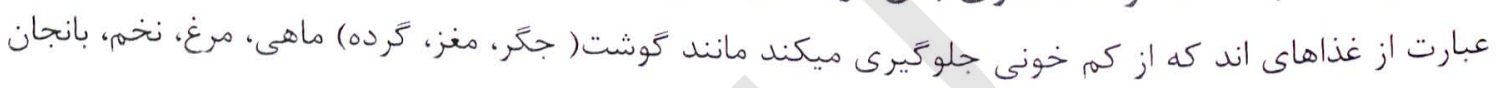
رومى، لوبيا، نخود، كَّالو، حَليى، شلغم، سيب، ميوه هاى خشك( خرما، بادام، كشمش) داراى مقدار آهن است. همجنان غذاهاى كه كلسيم دارند و سبب تقويت استخوان و دندان ها ميشود و عبارت اند از شير، ماست، ينير، تخمم سبز يجان، غذاهاى كه از جاغور و ضعيفى دماغ جلوكيرى ميكند عبارت است از نمك هاى آيودين دار و ماهى مى باشد. شعاع آفتاب براى جذب كلسيهم بسيار مفيد است بناً روزانه براى ها دقيقه قرار كرفتن در مقابل شعاع آفتاب مفيد ميباشد

غذاهاى حركتى و قوت دهنده بدن( كاربوهايدريت ها و شحميات)

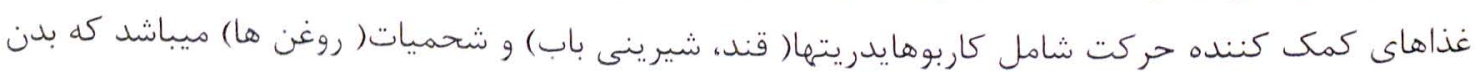
مارا قوت داده و ما را كمك ميكند تا از اين قوت خود در وقت كار و ضرورت استفاده نمائيم. 
فوايد خوردن غذاى خوب و متوازن

به افراد قدرت كار داده در مقابل امر اض وى را مقاومت بخشيده و صحتمند نتَّميدارد. دندانها و استخوانها را محافظت مينمايد.

$$
\text { سبب تقويه و نشو نماى طفل در رحم مادر ميشود. }
$$

به مادران كمك مينمايد تا بعد از ولادت زودتر خوب شده و قوت خود را بازيابد به مادران و اطفال كمك مينمايد در مقابل امر اض مقاومت داشته باشد.

$$
\text { سبب ازدياد شير نزد مادران شيرده مى كردد. }
$$

طرق ملوث شدن مواد غذايى

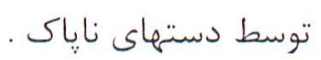

شستن و تهيه غذا با آب غير صحى

ملوث شدن با مواد فضله (توسط مغس ها و كرد و غبار)

استعمال نادرست ادويه ضد حشر ات در منازل، مزارع و باغ هلا

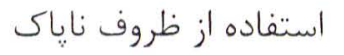$$
\text { محيط ناياك آشيزخانه }
$$$$
\text { توسط حيوانات و حشرات }
$$

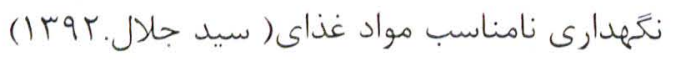

امراضى كه از سبب خورن غذاى ناياك و غذاى باسى( شب مانده) به وجود مى آيد

$$
\text { • • • • • • • • • • • • • • }
$$




$$
\begin{aligned}
& \text { محر قه } \\
& \text { L S } \\
& \text { فلج اطفال (يوليو) } \\
& \text { جلو كيرى از ملوث شان غنا } \\
& \text { دستهايتان راقبل از تهيه و صرف غذا عدا با آب و صابون بشوئيد. } \\
& \text { •از از ظروف پاى و سريوشيده براى نكَمدارى غذا استفاده شود. } \\
& \text { آشيزخانه تان را ياك نتَهداريد. } \\
& \text { براى تهيه غذا از آب باك استفاده نمائيد. } \\
& \text { سبزيجات و ميوه جات را ذبا آب باك و كلورين بشوئيد. } \\
& \text { غذا را بعد از خختن هر حه زودتر صرف كنيد } \\
& \text { در صورتيكه از غذاى شب مانده استفاده مى نمائيد قبل از خوردن بايد خوب كرم شود. }
\end{aligned}
$$

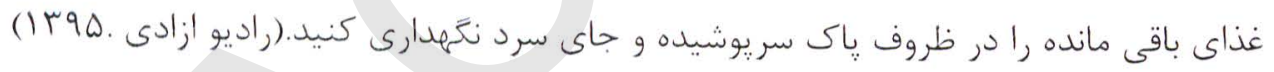

$$
\begin{aligned}
& \text { آب صحى آشميدنى صحى } \\
& \text { هر كاه آب از منابع آب صحى مانند نل، بمبه دستى، خاه سريوشيده، خشمةً سر يوشيده، كاريز سريوشيده } \\
& \text { استفاده كردد آب صحى كَفته ميشود. }
\end{aligned}
$$




$$
\begin{aligned}
& \text { موارد استفاده از آب صحى } \\
& \text { • } \\
& \text { • وضو } \\
& \text { • يخت و ريز } \\
& \text { • • شستن ظروف } \\
& \text { شستن بدن } \\
& \text { • • - شستن لباس } \\
& \text { منابع آب صحى }
\end{aligned}
$$

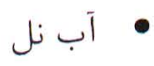

$$
\begin{aligned}
& \text { • بمبه دستى } \\
& \text { • جاهً سريوشيده } \\
& \text { • جشمهُ سر يوشيده } \\
& \text { • كاريز سر يوشيده } \\
& \text { آب هاى غير صنى } \\
& \text { جشمه هاى سر باز } \\
& \text { • جاه هاى سر باز } \\
& \text { • عاريز هاى سر باز } \\
& \text { • دريا ها و حوض ها }
\end{aligned}
$$




$$
\text { آب جشمه }
$$

آب جشمه در صورت كه به صورت درست محافظت گر دد هميشه پاك است. وقتى خوب محافظت شده ميتواند كه يك احاطه سمنتى و سنكى سريوشيده داراى دروازه در اطراف جشمه ساخته يا اعمار شده و دروازه آن هميشه

$$
\text { مسدود بوده و صرف در هنگام گرفتن آب باز گردد. }
$$

در صورت كافى بودن آب جشمه ميتوان يك يايب را در ديوار محوطه آن نصب كرده و آب را از آن بخَيريد.

$$
\text { آب }
$$

آب جاه معمولاً ياك است آنهم در صورتيكه درست محافظت شود. جاه وقتى صحى كَفته شده ميتواند كه:

حد اقل · ·ــــا متر دورتر از كنارآب يا انبار كثافات موقعيت داشته باشد.

حد اقل كامتر عميق باشد( در محلات كه سطح آب در زمين بلند است)

$$
\text { اطراف آن كانكريت داراى جك و سريوش باشد. }
$$

بايد اطراف خاه ياك ساخته و تمام آب هاى فاضله را از كنار آن دور سازد. يك آب رو براى خارج شدن آب باران داشته باشد

در صورتيكه جاه بمبه نداشته باشد بايد دو دوله داشته باشد و قبل از استفاده دست ها با آب و صابون

شسته شود

اءر تعداد زياد افراد در قريه يا محل تان مصاب به اسمال مى گردد لازم است تا بدانيد كه آنها آب آشاميدنى خود را از كجا بدست مى آورند؟ و جطور ز آن استفاده مى كنند؟ استفاده اب آشاميدنى غير

صحى اكثراً سبب اسمالات مى كَردد. (Ali akbari 1396) 


$$
\text { آب دريا }
$$

اكر منبع آب صحى آشاميدنى موجود نباشد:

بايد آب دريا را صبح وقت بكَيريد و آن را جوش، فلتر و يا در مغرض شعاع آفتاب قرار داده و بعداً از آن استفاده

$$
\text { شود }
$$

اب حوض ها

اكر منبع ديكًر براى كرفتن آب موجود نباشد ميتوان از آب حوض استفاده كرد. ( Central statistic (organization (2014)

$$
\begin{aligned}
& \text { طر يقه هاي صحى ساختن أب }
\end{aligned}
$$

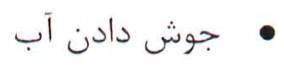

$$
\begin{aligned}
& \text { كلورين } \\
& \text { فلتر } \\
& \text { • م شعاع آفتاب }
\end{aligned}
$$

جوش دادن: در صورتيكه آب كل آلود باشد ابتدا آنرا در يك ظرف كذاشته تأ كل آن ته نشين كَردد بعداً وقتيكه جوش شد براى يك الى سه دقيقه جوشانده و آن را استفاده نمايد

كلورين: اين طريقه موثر براى صحى ساختن آب صاف بكار ميرود يك خط از سريوش بوتل را در ده ليتر آب

$$
\text { انداخته و بعد از ده دقيقه استفاده نمايد }
$$

فلتر نمودن: آب را از جهار طبقه ريك، جنل، سنكَريز هاى نسبتاً كلان و ذغال در يك ظرف فلتر نموده و صحى

بسازيد. 
شعاع آفتاب: آب رادر يك ظرف شيشه اى سربسته انداخته تحت Fr درجه سانتى كريد براى مدت جهار ساغت در منرض شعاع آفتاب قرار بدهيد( سعادت. צوبr)

مشكلات صحى در رابطه به صحت محيطى درتمام جهان مشكلات صحى يكى منشا محيطى دارد، بالخصوص ممالك فقير و روبه انكشاف به اين مشكل دجار ميباشد، ه تقريباً •ع الى •V فيصد امراض مصاب بودن و وفياترا نشان ميدهد. بخاطريكه در ممالك رو به انكشاف و فقير هنوز خدمات صحى بهتر در دسترس مردم قرار ندارد. زيرا اين ممالى تا به حال سيستم منظهم جابجا كردن مواد فاضله انسانى و حيوانى را ندارد و نه آب آشامدنى صحى در دسترس مردم قرار دارد. يكى مشكل عمده اى كه موجود است اين است كه در اين ممالك سظح سواد بسيار ٍائين به نظر ميرسد و مردم تا بحال اين مشكل راكل صحيح درى نه كرده اند . امراض سارى رابطه مستقيهم به محيط فرسوده و خراب دارد كه باث امراض كوناكون ميشود منجمله :

Ascarisis, tTyphoid, comman cold, enfluenza, shegilosis, اسهال، رِيجش، تب، انفلانزاى مرغى malaria,

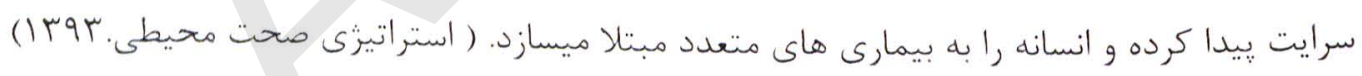
امراض و محيط ز زيست مردم امر اض را از محيط خود ميكَيرد. بعضى موارد شان مردم ميتواند درى نمايد، مثلاً: جروحات را كه توسط يك سطح صيقل شده ميرسد و يا زخمى شدن اعضا بدن توسط يك توته شيشه شكسته و يا اشيا تيز و برنده كه در سطح زمين قرار كرفته است. بعضى از امراض است كه علت هاى شان به آسانى ديده و محسوس شده نميتواند. (امراض سارى ) بسيارى از امراض است كه از حيوانات مختلف كه بسيار كوخى مايكروسكويى و قابل ديد نبوده شيوع مى يابد، عبارت از مايكروار كانيزم ها (دبكتريا، ويروس، فنكَس و يرازيت ها) ميباشد كه امر اض مختلف مثل اسهال، يِيجش، زدىى، 
امراض جلدى وغيره را ببار مى آورد. كه بنضى از اين امراض شاييد بسيار به حالت وخيه برسد و منجر به مركى انسانها كر دد، بعضى از آنها جدى نبوده ولى آزار و ازيت دهنده است. فكتور هاى محيطى منشاى اصلى امر اض ميباشد بالخصوص در ممالك روبه انكشاف، از روى يك احصائيه هץ\%

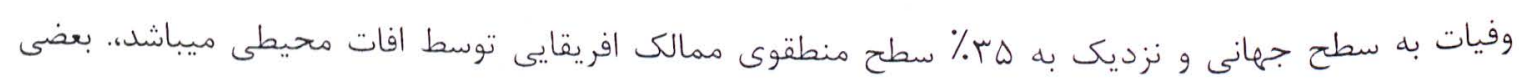
ساحات كليدى خطر قرار ذيل ميباشد:

أبهاى نا مصَّون، حفظ الصحه ضعيف نزديك به V، إيليون انسان را سالانه از بين ميبرد، بالخصوص در نتيجه امراض اسهالات به حواله (psi.org) سالانه ه، اميليون كودى جانهاى خود را توسط امراض اسهال از دست ميد هند. دود داخلى خانه كه اين دود ها توسط سوخت فوسيلى به اندازه צ، اميليون انسانها را توسط امر اض تنفسى سالانه از بين ميبرد.

ملاريا سالانه r، أميليون انسان را از بين ميبرد، كه اكثريت شان كودان افريقايى ميباشد اين امرض توسط ديزاين

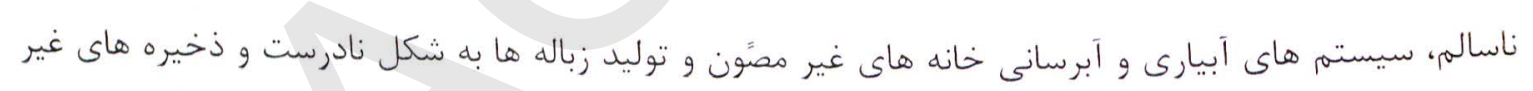

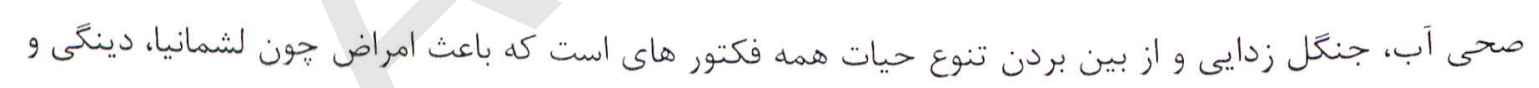
ملاريا ميشود. آلودكى هوا در شهر ها كه توسط وسايط، كار خانه جات به اندازه ..... مردم را سالانه از بين ميبرد زهرى شدن حاد . . لهه مردم را سالانه از بين ميبرد. در ممالك رو به انكشاف دو بر سه مرك مير توسط اين

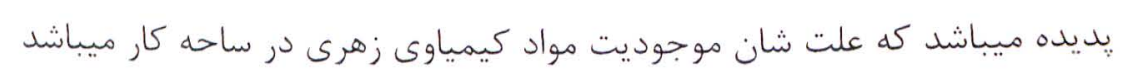
تاثيرات تغير اقليم همجنان تاثير عميق بر وقايع اقليمى دارد كه باعث تغير شكل امراض و تاثيرات شان بر توليدات زراعتى ميباشد، كه اين را هم به اندازه .... الم مردم سالانه محاسبه نموده است 
افغانستان از لحاظ حفظ الصحه محيطى ى مملكت بسيار عقب مانده است. زيرا مردم افغانستان تا هنوز به آب آشاميدنى صحى و ياك دستر سى ندارد.سيستم تنظيم زباله بالخصوص مواد فاضله انسانى و حيوانى به شكل درست وجود ندارد كه اين همه مشكلات و عقب ماندگى ها باعث امراض سارى ميباشد كه به اشكال مختلف صحت انسانى را در افنانستان متضرر ميسازد. ( استراتيرى صحت محيطى.بوج ( )

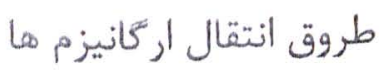

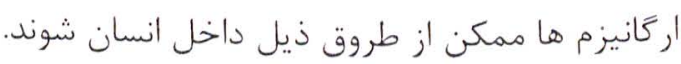

از طريق تنفس: طوور مثال مرض توبر كلوز توسط قطرات هوايى اثر عطسه، سرفه و سخن زدن از شخص مريض به اشخاص صحتمند انتقال يابد. از طريق جلد: ممكن بعضى امراض توسط جلد داخل بدن انسان كردد. كه مشكلات صحى را ببار ميآورد. مثلاً ويروس سگ ديوانه كه از اثر كندن سگ انتقال ميكند. توسط خوردن و نوشيدن: به وسيله خوردن آب ملوث و مواد غذايى ناشسته شده و مصاب از طريق دهن انتقال

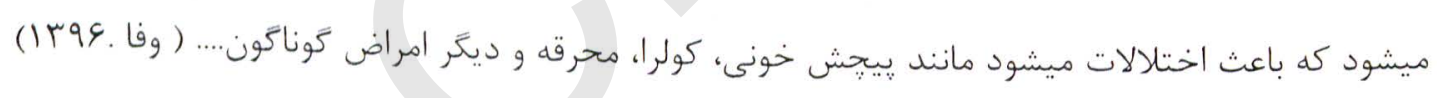
ناقلين امراض ناقل عبارت از حيوانى ميباشد كه مرض را از يـ حيوان و يا شخص مريض به ديخر حيوان و يا شخض سالم انتقال ميدهد او به مرض بالمثل مبتلا ميسازد و قرار ذيل اند: حشرات مانند يشه ها و مخّ ها حيوانات آب مانند حلزون در خشكه مانند موش

در اكثر مناطق جها ن خصوصاً در مناطق تروييك و گرمسير تعداد زياد حشرات و حيوانات مانند پشه ها، مخسهها،

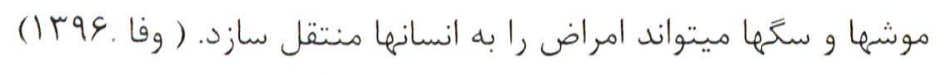




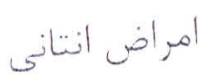
امر اض انتانى عبارت از امراض اند كه توسط ميكروب از يك شخص به شخص ديكًر انتقال ميكند انتان عبارت از يروسه معرفى شدن ميكرواركانيزم به ميزبان است كه به تعقيب داخل شدن در عضويت شروع به تكثر ميكند. جهت بروز امر اض انتانى بايد شرايط محيطى براى آن مساعد باشد. مثال هاى امر اض انتانى كولرا، توبر كلوز وغيره... ميباشد. (وفا .و9rا) دوره تفريخ عبارت از فاصله زمانى بين داخل شدن انتان در عضويت ميزبان و ظهور اولين اعراض مرض ميباشد اين فاصله در امر اض مختلف فرق ميكند دانستن راجع به دوره تفريخ امر اض كمك زياد در وقايةً آن ميكند در جريان اين دوره

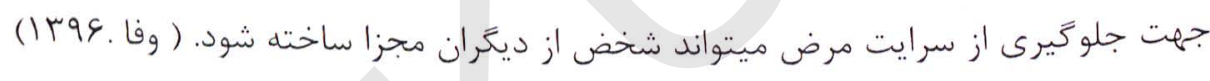

\section{دوره تفريخ}

نام امراض

קند ساعت تا ينج روز كولر

$$
\begin{aligned}
& \text { ينج الى هفت روز } \\
& \text { سرخكان } \\
& \text { يك الى دو روز } \\
& \text { آبجيجى } \\
& \text { سه الى بنج روز } \\
& \text { ديفترى } \\
& \text { دوهفته الى دو ماه } \\
& \text { تيتانوس } \\
& \text { دو هفته تا دو ماه } \\
& \text { مرض سگ ديوانه } \\
& \text { هفت الى دوازده روز } \\
& \text { سياه سرفه }
\end{aligned}
$$

\section{قرنطين}

عبارت از تجريد نمودن شخض مشكوك مواجه به انتان در جريان دورةً اعظمى تفريخ مرض است. 
دورة ايست كه در جريان آن اركانيزم از شخص مريض مساعد انتقال ميكند. طور مثال در سرخكان اين دوره ·1 روز در آبجيجك r-r هفته، در سياه سرفه ا-ع هفته، در يوليو r هفته و در كولرا ا-ب هفته ميباشد.

ملاريا

ملاريا عبارت از يك نوع مرض خون است، كه توسط يشه ها انتشار رِيدا ميكند.

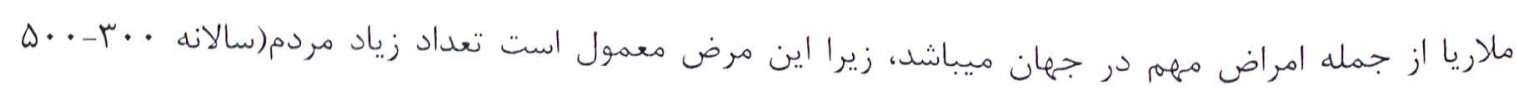
ميليون نفر) را مريض ميسارد و سالانه در حدود ه، الى ب ميليو نفر را هلاك ميسازد.

ملاريا از سبب يك يرازيت كوجى وحيد الحجروى كه در جَّر و حجرات خون انسانها زندكى ميكند، بوجود ميايد. هُندين نوع مختلف يرازيت ملاريا موجود است، كه در افغانستان دو نوع آن(وايوكس و فلسيارم) سبب مرض ميشود كم نوع دوم آن خيلى خطرناك و كشنده است. ( وفا . عوبا ) انواع منتئف يلازمودينم:

Plasmodium vivax

Plasmodium falciparum

Plasmodium malaria

Plasmodium ovale

Plasmodium knowlesi

يشه انافيل موَّث يرازيت ملاريا ,ا در وقت مكيدن خون از شخض منتن ميكيرد. برازيت جندين مرحله نمو را در وجود يشه طى ميكند بعد از يك هفته، وقتيكه يشه شخص ديخر را بخزّ او را نيز با برازيت ملاريا منتن ميسازد.

در ساحاتى كه ملاريا معمول است اكثر مردم معافيت طبيعى محدود به مقابل ملاريا كسب ميكنند، از اينرو معمولاً اعراض و علايم ملاريا نزد شان يا بروز نميكند و يا بسيار خفيف ميباشد. در صورتيكه جنين اشخاص ساحه ملاريائى 
راترك كند معافيت خد را از دست خواهد داد. اگر خنين اشخاص به ساحه معمول ملاريا دوباره برگشت كنيد و

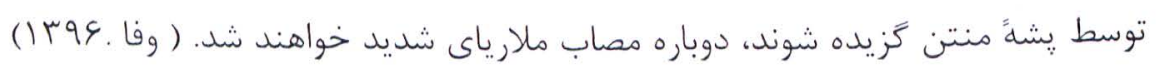

\section{وقايه ملاريا}

ملاريا به سه طريقه ذيل جلو گيرى شود كه پشه در آنجاها زندَّى و تكثر ميكند. كنترول پشه ها در ساح ضرورت به همكارى اجتماع و ديكر تيم ها دارد.

به مردم تعاليم دهيد تا خود را از زَزيدن رشه ها با استفاده از جالى يا ٍشه خانه هاى آلوده با حشره كش ها و لباس هاى مناسب محافظت كنند در استفاده از رشه خانه ها به اطفال و خانم هاى حامله حق اولويت داده شود. اخذ تابليت هاى كلوروكين هفته يك مرتبه ميتواند مردم را از ملاريا حفاطت كند. تشخيض به موقع و مراقبت مريض ميتواند انتشار مرض را كنترول كند. به مردم راجع به اعراض مقدم ملاريا تعليمات دهيد. ( وفا . (1) )

توبر كلوز يك مرض انتانى شديداً سارى است و توسط TB Mycobocterium بوجود مى آيد مر يضتوسط قطرات مواد منتن، عطسه و سرفه از شخص منتن به شخص سالم انتقال ميكند. اطفل كمتر از ه سال و كاهلان با سنينين ريشرفته بيشتر در معرض خطر قرار دارند. فكتورهاى ديكر خطر عبارت از يائين بودن مقاومت بدن از سبب سوٌ تغذى، مرض شكر، امر اض قلبى و مراض كَناكون ديخر است. 


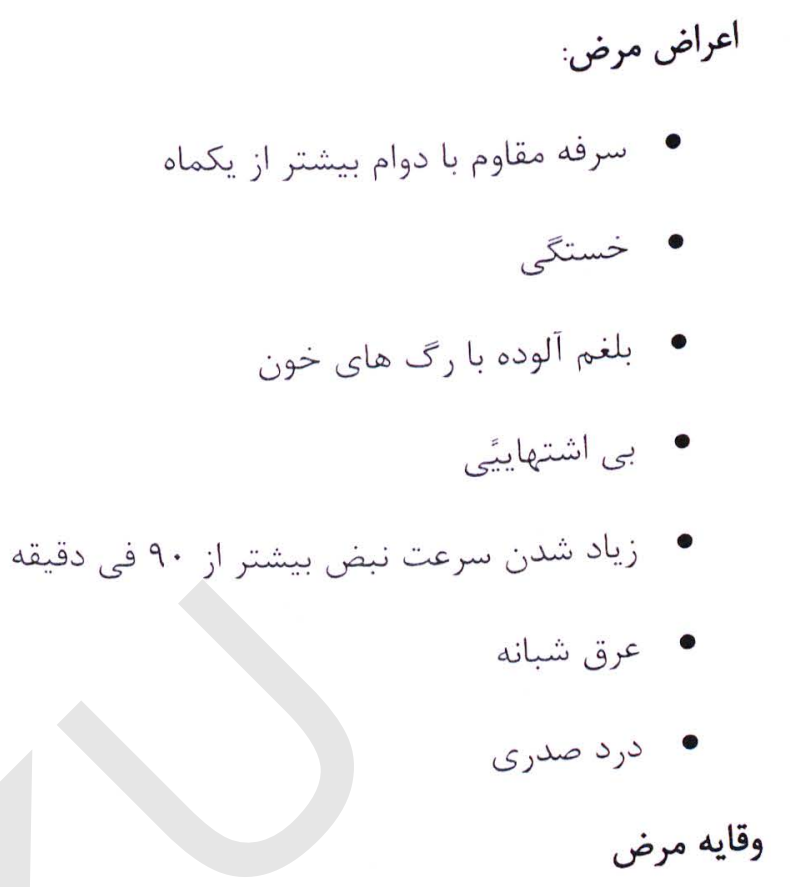

به فاميل ها توصيه نمايد تا اطفال خود را واكسين B.C.G نمايند. كسانى كه به تماس واقعةً توبر كلوز اند، جهت معاينه بلغم X-Ray معاينات ديكر به شفاخانه راجع شوند. اعضاى فاميل و مريض را تشويق كنيد كه از غذاى خوب تغذيه نمايد. ( وفا .وجr 1) مرض كرم زمينى

اين مرض در جهان از جمله امراض عام شمول ميباشد، كه در كشورهاى فقير و نادار زيادتر به خشم ميخورد. اين مرض كه توسط تخم كرم سرايت ميكند در مواد غايطه انسان موجود ميباشد، كه توسط سيستم بدرفت غير صحى باعث آلوده شدن خاى ميشود. انواع عام آن كه باعث مريضى در انسانها ميشود عبارت اند از اسكاريس لومبر كايدس Ascaris lubricoides، ترايجوريس ترايجوريا.Trichuris trichiurat، هوك ورم ميباشد. 
ايدز يك مرض است كه به شكل دوامدار يك مشكل صحى جهانى ميباشد كه بيشتر از وبم ميليون نفوس در جهان مرتبط با ايدز زندگى مينمايد. از V، ا ميليون مردم از اين مرض هلاك كَديده است.

به اندازه هr ميليون مردم در جهان با وايروس ايدز HIV زندكى ميكند و در اواخر سال rا •r ميلادى l، ميليون نفر تازه به مرض گرفتار شدن.

ممالك افريقا متاثرين بيشتر جهان را تشكيل ميدهندكه اندازه شان در سال rا •r ميلادى به t، يليون تن كه با ايروس HIV زندگى ميكند ميباشد كه اين ممالى .V\% جهان را كه تازه به اين مرض مبتلا شده را تشكيل ميدهد

مرض ايدز HIV توسط معاينات خون كه در آن موجوديت يا عدم وجوديت انتى بادى ايدز معلوم ميشود تضخيض ميخر دد. به حواله سازمان صحى ملل متحد در افنانستان • ل ا I وقايع ثبت شده ولى UNAIDS سازمان صحى ملل متحد

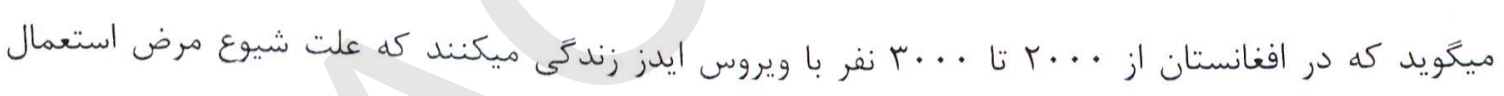

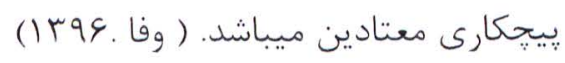

شيوع ويروس مرض ايدز توسط معاينات خون، شير مادر، و روابط جنسى از شخص مبتلا به وجود شخص سالم سرايت ميكند.

انفلانزاى مرغى AVIAN INFLUENZA مرض انفلانزاى مرغى تلفات زيادى دارد نشانه هاى آن در ب الى V حوز نمايان ميشود ويروس مواد ارثى ميباشد موجوديت مرض ايدز براى اولين بار در ها مى سال r. . r در تهندين فارم مشكوى تائيد شد 
ارتباط مستقيم و غير مستقيهم يرنده هاى مهاجر با يرنده هاى اهلى در جاهاى خريد وو فروش يرنده ها در جاهاى رفت و آمد انسانها و حيوانات و توسط وسايل ترانسيورتى توسط غذاى ناسالم و غير صحى به شكل درست به حفظ الصحه توجه نكردن

حفظ المحه محيقلى نر شهر كابل كابل ״ر جمعيت ترين شهر هاى افغانستان ميباشد كه به اساس كَزارش ها هم اكنون ع ميليون نفوس نفر در اين شهر زندگى ميكنند. در حال طى • الس كذشته، ده ها بلند منزل در اين شهر اعمار شهه است كه بيشترين ين بلند منزل ها به شكل غير معيارى كه داراى سيستم كاناليزاسيون هعيارى نبوده ميباشد. از نظر صحى اين شهر به علت داشتن نفوس بيش از حد و عدم موجوديت امكانات مناسب براى حفظ الصحه در خطر جدى قرر دارد كابل ازجمله شهر هايى است كه ميزان آلودكى هوا ومحيط زيست درآن به شكل نكران كننده يى روبه كُترش بوده وبراساس آمارهاى موجود روزانه ده ها نفر بنا به آلوده گى محيط زيست به امراض تنفسى و ساير امراض كرفتار مى شوند. كابل پايتخت كشور شهرى است كه آلودگى آن به كونه سرسام آور و نكَران كننده اى بالا رفته و اين در حالى است كه هيجَّونه تدبير و سازوكارى مبارزاتى با اين بديده از سوى دولت وجود ندارد. روزانه ميليون ها ذره سمى و مكروبى از كوجه ها و پس كوخه هاى كابل برخواسته و در كنار دود و گردوخاك بر فضاى تنفسى شهروندان كابل مستولى گرديده و به هواى تنفسى اين مردم تبديل مى كردد. هواى كابل دربسيارى اوقات به حدى آلوده با دود وخاى و ديكًرعوامل آلوده كننده است كه اكثرا درهوا جترتاريك ومكدرى را برفضاى شهربه وجود مى آورد و 
در زمين هم خاى وتعفن ناشى ازمواد مختلف آلوده كنيده، افراد را كرفتارمشكلات عديده يى مى سازد. درجنين وضعى امراض مختلف جسمى و روانى ايجاد كردديده و زندَّى مردم را تهديد مى كند. آلودىى هواى شهر هاى افنانستان به خصوص كابل عمدتا ناشى از مصرف بى رويه مواد نفتى در موترها و وسايط نقليه، خرابى جاده ها كه دربسيارى موارد باعث ايجاد كرد و خاك مى شود، نبود ساحات سبز كه براى تصفيه هوا وجلوكيرى از بروز گرد وخاى نهايت موثراست، فقدان سيستم كاناليزاسيون و سايرامكانات رفاهى درجامعه و درنهايت بى توجهى مردم براى نكَمهارى محيط زيست بوده وعلى رغم نَّرانى هاى شديد از رشد روزافزون آلوده

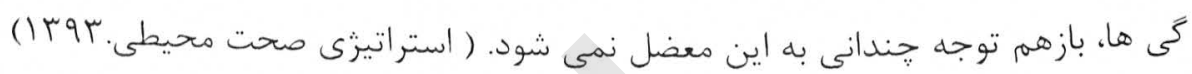
در كابل تنها هوا آلوده نيست، بلكه آلودگى صوتى يكى ديخر از مسايل و معضلات اجتماعى خطرناكى مى باشد كه نسبتا كمتر از آن سخن كَته مى شود. با كَّت و كذار در سطح شهر و سرك هاى كابل، به زودى متوجه اين امر مى شويد. شهروندان كابل، خصوصا كاسبان و بازاريان اندك ترين هنجار هاى شهرنشينى را در نظر نگَرفته و ملاحظه سايرشهروندان و مردم را نسبت به امنيت و آرامش صوتى در نظر نمى كَيرند. موسيقى هاى كه از بلندكوهايى قوى بر فراز دروازه هاى هوتل ها، رستورانت ها، كست فروشى ها و خدمات ثبت و صوت در شهر كابل بلند مى شود، جنان طنين منزجر كننده اى را خلق مى كند كه تحملش براى دقيقه اي هم براى عابرين هم دشوار مى باشد، خه رسد به آنانيكه در اطراف آن زند گى كرده و يا روز كامل را به منظور كار آنجا سيرى مى نمايند. يا مثلا موتر هاى ملى بس و وسايط شخصى هيجَُّونه احترامى به آرامش مردم و محلات خاصى خون شفاخانه ها و مدارس و دانشعاه ها نداشته و با هارن هاى بى موقع و اغلبا بلند، آرامش و روان صدها انسان را كه. در اطر اف آن هستند، به همم مى زنند. اين در حالى است كه دولت هيجگَونه مقر راتى در اين خصوص نداشته و يا حداقل در اين مورد بر رفتار و كردار مردم كنترل ندارند. در كنار امنيت جسمى، نظهم و قانون، تامين امنيت و آرامش روحى و روانى مردم و برقرارى نظهم جمعى در شهر از مسئوليت ها و وظايف اصلى دولت بوده و دولت مكلف است تا از آرامش روحى و روانى مردم ياسدارى نمايد. 
هر خند شهردارى كابل ازتلاش هاى جديد جهت ايجاد ساحات سبز در اين شهرخبرداده و كفته است كه اين نهاد براى اين كارفعاليت هاى خودرا تشديد بخشيده است، اما به كَمان مى رسد تنها تلاش شهردارى براى رفع اين مشكل حاد، نمى تواند رهكَشا باشد؛ زيرا با توجه به كُستردَى دامنه بحران زيست محيطى در كشور، اين كارنيازمند عزم جدى است كه بايستى نهادهاى مختلف مسئوول در اين راستا سهم بخيرند. رسيده گى به اين مشكل از دوجنبه مى تواند موثرباشد؛ يكى نظهم بخشى به صورت ظلاهرى شهرها است كه شامل ساخت وساز جاده ها، ايجاد ساحات سبز، وضع مقررات جدى تربرتجارت مواد سوختى ونحوه استفاده ازآن دركشور وهر آنجيز ديخَى كه مى تواند درين راستا موثرواقع شود. دوم، بايستى نهادهاى مسئول براى نهادينه سازى فرهنگ حفاظت ازمحيط زيست درميان مردم تلاش نمايد. تنها رسيده گى وسروسامان دهى به صورت ظاهرى شهر ها نمى تواند، موثريت قاطعى براى بهبود محيط زيست داشته باشد. آنجه كه مى تواند موثريت اين كار ها را تضمين كند كَسترش فرهنَ حفاظت از محيط زيست درميان مردم است كه با اين كاريك عزم همعًانى براى نكَهدارى محيط زيست به وجود مى آيد. بسيارديده شده است كه مردم خودعملا به دليل بى مسئووليتى و يا عدم آكاهى ازمسئووليت هاى زندَى شهرى، سهم درست وجشمخيرى را براى نَّمدارى محيط زيست بر دوش نمى كشند، ولى اكر اين فرهنَ درميان مردم اشاعه داده شود ومردم براى همكارى با نهادهاى مسئول فراخوانده شود، موثريت كارها واقدامات حندين برابرخواهدشد. ( استراتيزى صحت

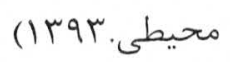
در اين ميان مردم نيز تاحد زيادى مقصر مى باشد. مردم اندى ترين توجهى به محيط زيست خويش داشته و هيجًاُونه هنجار بهداشتى و شهر نشينى را مراعات نمى كند. براى تامين محيط زيست سالم، همكارى مردم با شهردارى و ساير نهادهاى مربوطه الزامى بوده و در صورتيكه برنامه تامين محيط زيست سالم همكارى و هميارى مردم رانداشته باشد، نميتوان به محيط زيست سالم و پاى اميدوار بود. محيط زيست (Environment)، آلودكى (Wollution)، آب (Water) وهوا(Weather): 
آب، هوا، خاك، اكوسيستمم مانند جنحلات و حيات وحش را در مكان محيط زيست مى كويند . بحران محيط زيست و آلودگى هاى آب و هوا، وضعيت ناهنجار، وخامت زيست شهرى بيك تهديد بزرگى در برابر سلامتى شهروندان شهر كابل تبديل شده و روز بروز جدى تر و بدتر شده ميرود. آلودگى آب و هوا ناهنجاريهاى بيشترى را بار آورده و باعث ايجاد بيمارى هاى صعب العلاج، معلوليت هاى دائمى، سوء شكل اندام نوزادان و ساير مشكلات مادر زادى ديكرى ميشود.

اين آلودگى ها و تخريب محيط زيست ناشى از عوامل ذيل اند: 1-1: سه دهل جنَ تحميلى استعمارى و ارتجاعى و فرو ريختن خروار ها تن بهم و مواد زهرى(به شمول بم هاى خوشه ئى توسط روس ها و استعمال بم هاى حاوى يورانيم ضعيف شده در منطقة توره بوره و شايد جا هاى ديكًر و بم هاى فاسفورس دار توسط اشغالكران امر يكائى - ناتوئى) علاوه از كشتار هموطنان ما، آب، خاى و فضاى كشور ما را آلوده به مواد زهرى ساخته است. r-1: كسترش روز افزون اثرات مخرب وسايط نقليه وعدم كنترول و نظارت بر توريد انواع تيل و روغنيات مصرفى وسايط نقليه و مؤدل :ِائين بس هاى شهرى، جاده اى، ماشين هاى قديمى كار كَاهمبا و كارخانجات با افرازات كازات مضره حاصل از احتراق مواد سوخت در انجن هاى ديزلى، توليد دود و عازات مضر ه در هوا، امواج صوتى ماشين آلات توليدى ماشين هاى قديمى، طيارات كهنه و از مود افتاده، پار كينك ها و ترانسبورت ها در محلات رهايشى، موتر هاى مودل يائين به بازار ها و مواد سوختى خبازان، حمامها، دكاكين و منازل از مواد سوختى دود زا جون(

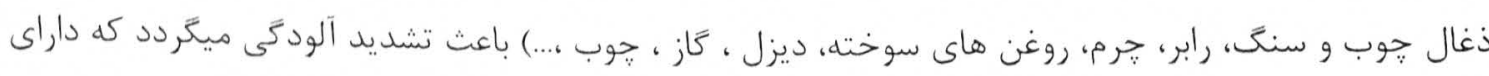
خاصيت ذيل اند: ا - كاربن مونو اكسايد(CO) در غلظت هاى كم بسيار خطر ناى بوده و يك ماده كازى - بى بو و بيرنگ و بى ذايقه است. اعر جذب بدن انسان گر دد، سيستهم آكسيجن رسانى به بدن راغير فقال ساخته و در مدت كم سبب مرى 
r- هايدروكاربن ها (HC) مواد سوخته و يا نيمه سوخته اند وسبب توليد دود و غبار كرديده -- و باعث امراض سرطانى ميگردد

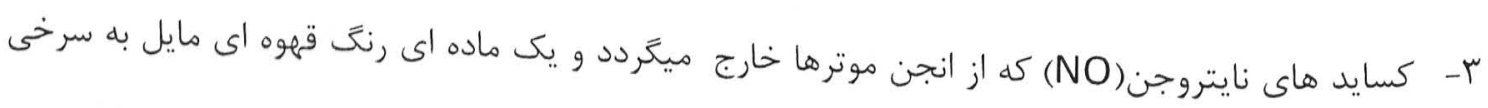
، بوى تند و ززنده دارد، در صورت استنشاق به دستخاه تنفسى انسان آسيب ميرساند. "-1 1: عدم توجه به توليدات و توريدات مواد غذائى، ادويه جات صحى، ادويه زراعتى، كود كيمياوى، البسه باب،

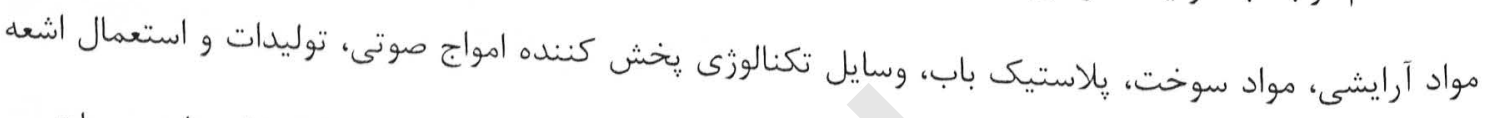

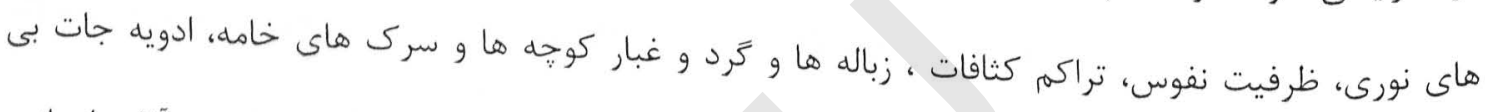

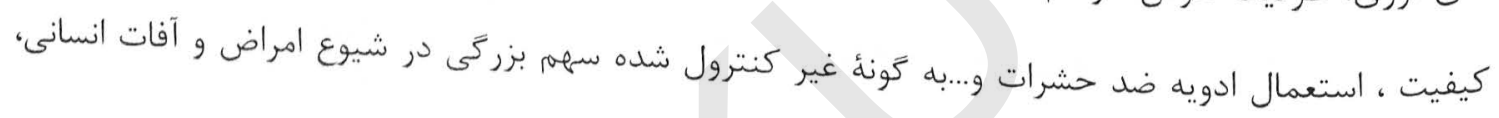
حيوانى و نباتى و آلودگى هوا دارد. ( استراتيزى صحت محيطى.بrوب (1)

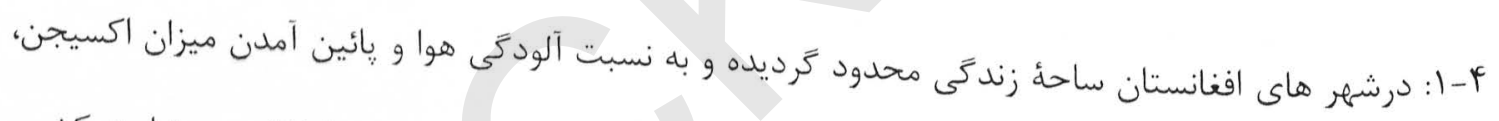

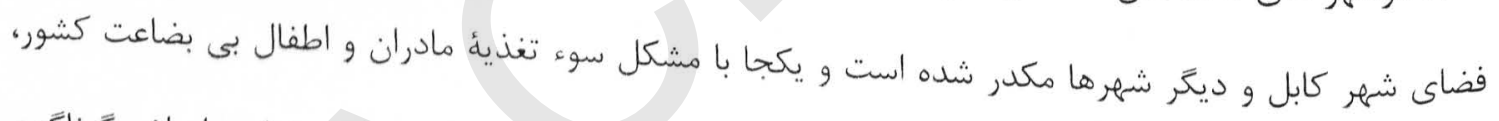
باعث مرى و مير مادران و نوزادان، ضعف فكرى كودكان، نقص اعضاء، بروز امر اض حيوانى و نباتى، امراض كوناكون تنفسى و قلبى، سرطان، مشكل سيستم تنفسى، امر اض جلدى، حساسيت ها و حتى تاثيرات سوء بر نسل آينده

ه-1 1: نبود يك سيستم كانالزيسيون و مجراى فاضلاب از سطح شهر و حفر خاه هاى فاضلاب انفرادى خانواده ها بدون توجه به عايق محافظتى و باز دارنده از نفوذ آن در زير زمين و در نهايت آلودكى آب هاى زير زمين در شهر كابل از جدى ترين مسله آلودگى محيط زيست بشمار ميرود. قطع درختان و جنگلات و نابودى ساحات سبز،

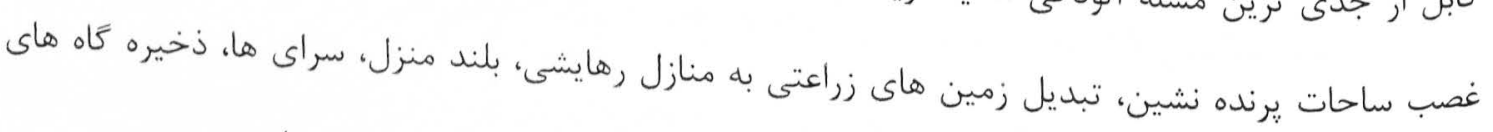
مواد احتكارى اوليه زندَّى دلالان كميرادور و اعمار دو كانها و... ساحات سبز را از بين برده است. 
اثرات مخرب روند جارى تخريب محيط زيست در شهر ها و اكناف كشور ميتواند علاوه بر نسل حاضر نسل هاى آينده را نيز جداً متأثر سازد.

ارتجاع جمع شده در دولت دست ساخت اشغالكَران غير از غارت، خيانت بوطن، قطع جنحًات، غصب زمين هاى زراعتى توسط مافياى دولتى زمين، توسعة كشت و قاحاق مواد مخدر، ثروت اندوزى و جفا در حق مردم، كدام

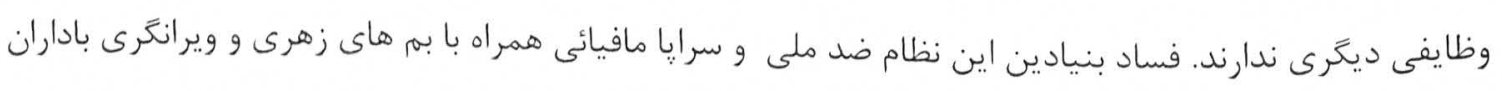
اشغالكرش محيط زيست طبعيى ما را نيز مانند محيط اجتماعى ما فاسد و تخريب ساخته است. كشور عزيز ما كه سرشار از منابع آب شرين بود با قدوم ناميمون قواى اشغالكران اميرياليست جهانى نه تنها فضا و آب هاى روى زمينى آن، بلكه آب هاى زير زمين اكثر شهر هاى ما نيز بخصوص شهر كابل را آلوده شد.

\section{سواد}

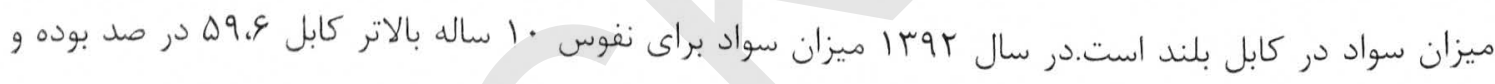

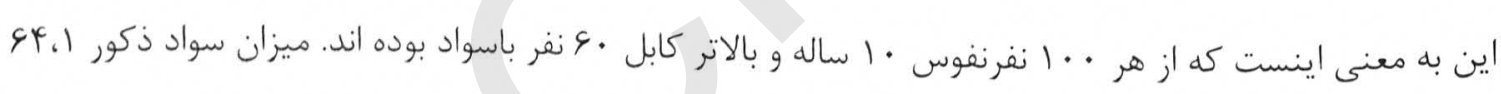
بوده كه تقريبا ميزان آن دوبرابر اناث است.

\section{درجه تحصيل}

درجه تحصيلى بلندترين سطح تكميل شده تعليمى توسط افراد است و توسط آزمايش ارقام در مورد بلند ترين صنف،يا سطح تعليمى تكميل شده توسط اشخاص هrساله و بالاتر از آن، زمانيكه يك فرد به صورت عادى مكتب يا سهمغيرى در موسسات قبل از ليسانس، و سطوح يا درجه هاى مختلفه تحصيلى( بكلوريا، ليسانس ،ماسترى و دوكتورا) ارزيابى ميگر دد. بيشتر از نصف ساكنين ه V ساله و بالاتر كابل به هيج مكتبى نرفته VV.V فيصد ويا به مكتب رفته ولى درجه تحصيلى را تكميل نكرده اند. 9, 94فيصد تعليمات مسلكى و تحصيلات مسلكى عالى حضور داشته يا تكميل كرده اند. ( استراتيزى صحت محيطى.بوr (1) 
منبع عمده انرزى براى تخت و يز

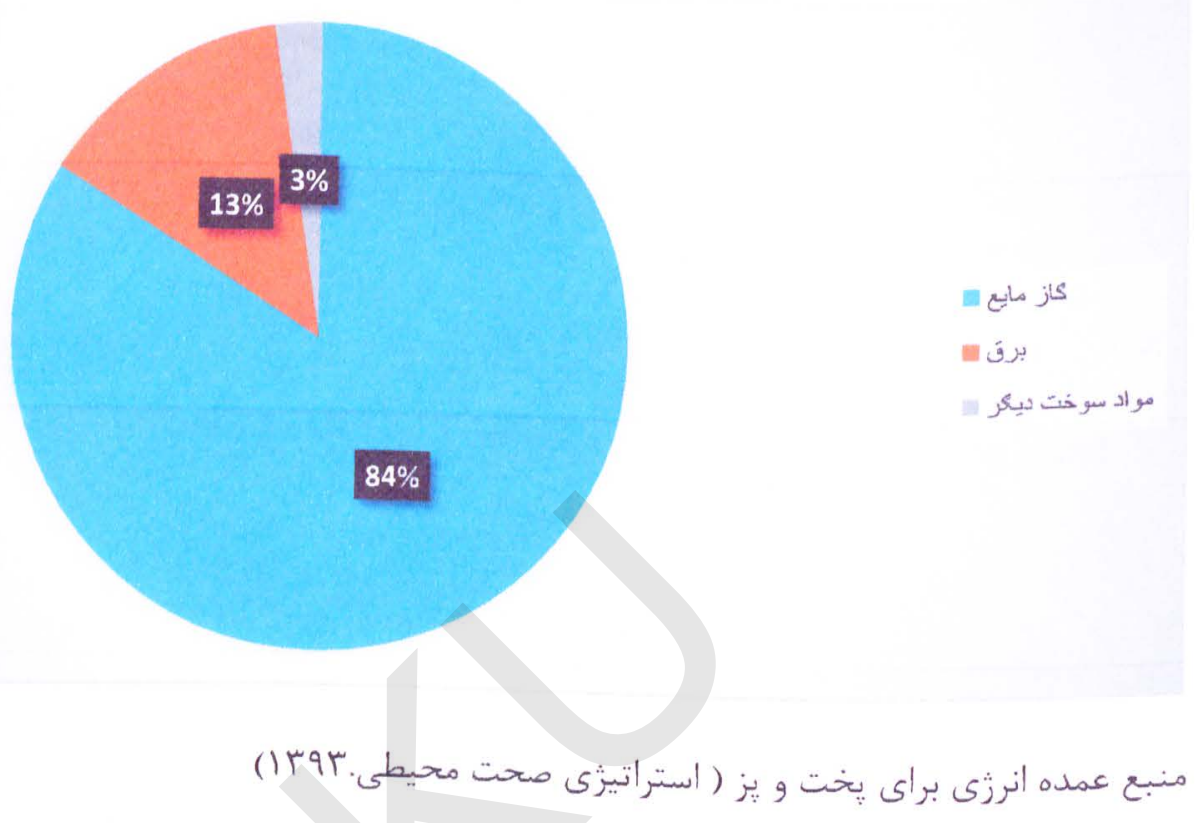

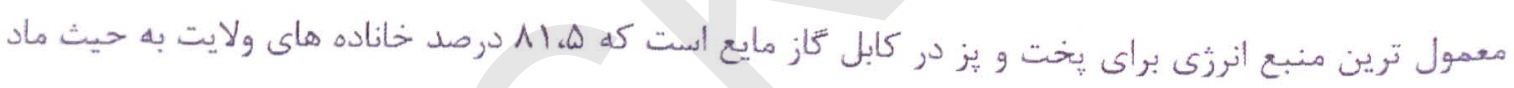

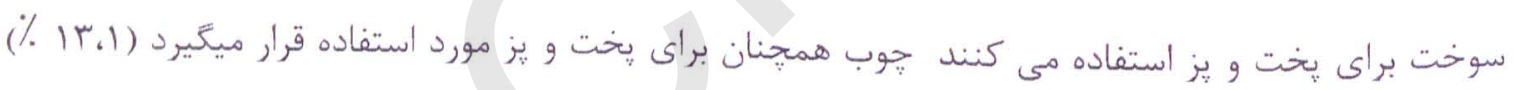

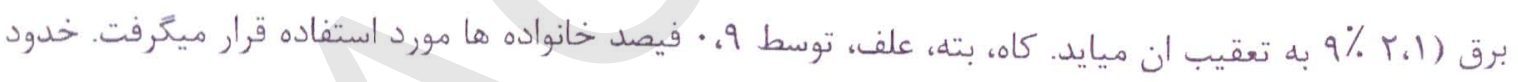
ه.r فيصد متباقى انواع ديكر مواد سوخت مانند تيل خاك، ذغال جوب، ذغال سنكُ سركين حيوانات و باقى مانده مواد زراعتى را مورد استفاده قرار ميدهدبر. در شهر كابل 9 خانواده از هر • إنواده از كاز مايع براى قخت و يزاستفاده ميكند. 


\section{منبع عمده مواد سوخت براى تسخين}

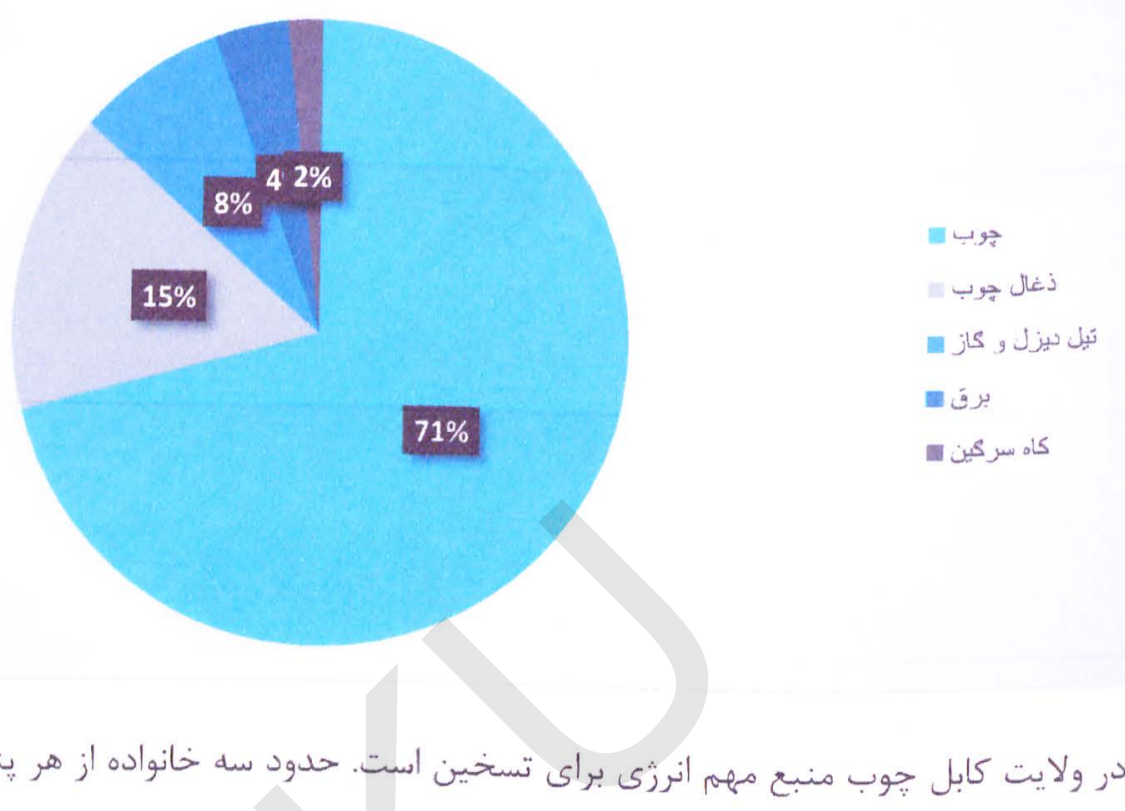

منحيث مواد سوخت براى تسخين مورد استفاده قرار ميدهند ذغال جوب توسط \&، ال فيصد و ديزل، تيل خاك

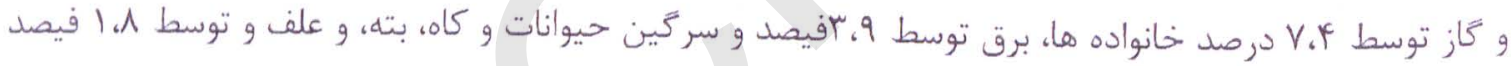
خانواده ها موده استفاده قرار ميخيرد. 9، و درصد ديثر خانواده ها از ساير انواع مواد سوخت مانند ذغال سنك، براى تسخين اسنفاده ميكنند. 
منبع عمده انوزى براى تثوير

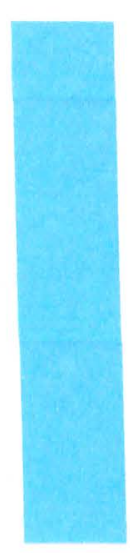

بر

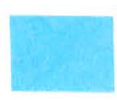

انترزى أفتاب

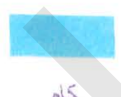

نَبل خاك

برق منبع بيشتر و انرزى جهت تنوير در ميان خانواده هاى ولايت كابل بوده. و توسط حجهار خانواده از هر ينج

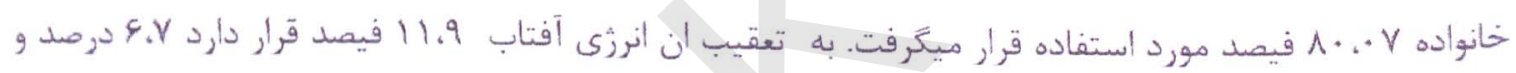
A، • درصد و متباقى به ترتيب از كاه، تيل خاك و ديكر منابع انرزى مانند شمع استفاده ميكنند. تقريبا همه اي خانواده ها در شهر كابل از برق( برق دولتى يا برق آبى، جنراتور) براى تنوير 9، • 9 فيصد استفاده ميكنند.

منبع عمله آب اشاميدنى، شست و شو، هخت و هيز و دكر موارد استفاده
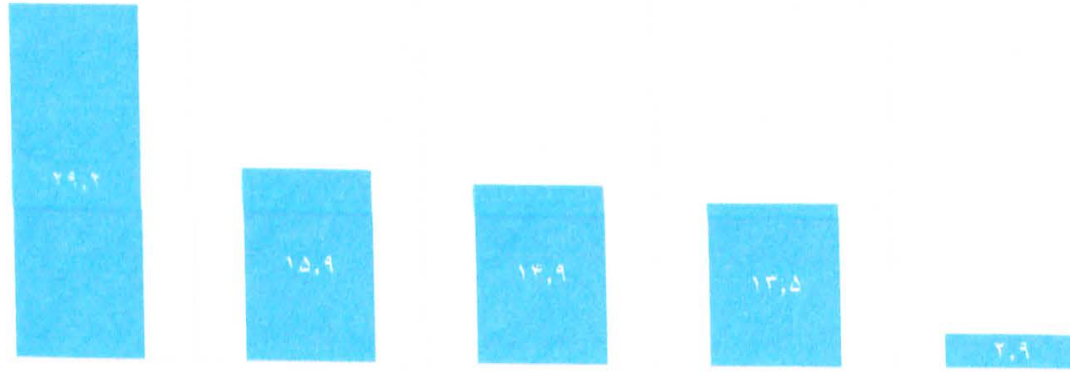
$=2$ :

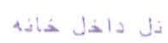
أب جاء بز بهد
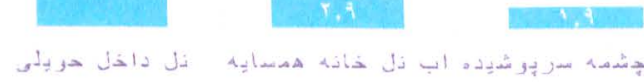
״اه سريوشيده معمولترين منابع آب آشاميدنى در كابل است. در حاليكه r. r فيصد خانواده ها آب آشاميدنى خود را الين منبع به دست مى آورند. در حاليكه 9،ه ا فيصد آب خود را از نل واحد داخل مسكونى بدست مياورند. در تمام ولايت فيصدى بالا VA، فيصد از مجموع خانواده ها به آب آشاميدنى بهبود يافته دسترسى داشتند

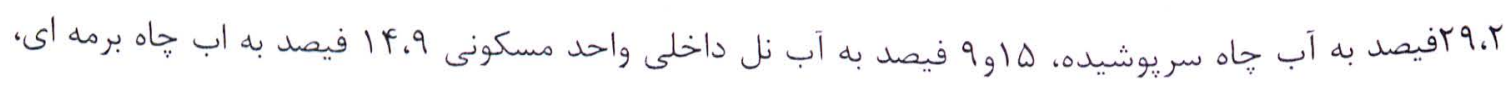
ه، rا فيصد به آب نل داخل حويلى، 9، ج فيصد به آب نل داخل خانه همسايه و 9، 1 فيصد به آب خشمه سر يوشيده. در شهر كابل منبع عمده آب آشاميدنى خاه سر يوشيده بهبود يافته در شهر كابل 1r، فيصد از مردم به آب آشاميدنى صحى دسترسى دارند. آب خاه سر يوشيده همجنان منبع آب براى شستشو، پخت و يز و ديخر مقاصد براى بسيارى خانواده ها در ولايت كابل ميباشد.( راديو ازادى .0ه (1)

مالكيت زمين

در ولايت كابل يك خانواده از هر خانواده مالى زمين زراعتى است، شبر كابل نسبت ياينترين خانواده هاى را دارد كه مالك زمين زراعتى است. مالكيت مواشي و طيور در تمام ولايت و،ه فيصد تمام خانواده ها مالى يك عاو، كَاو شيرى، كَاو نراساسا براى غذاى خانواده( شير، ماست، كَشت، روغن، قروت)و يا بخاطر تهيه مواد سوخت (سرَين) براى رخت و يز و تسخين بودند اكثر خانواده هاى

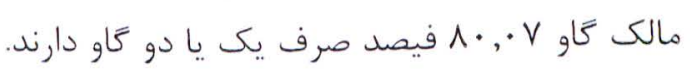

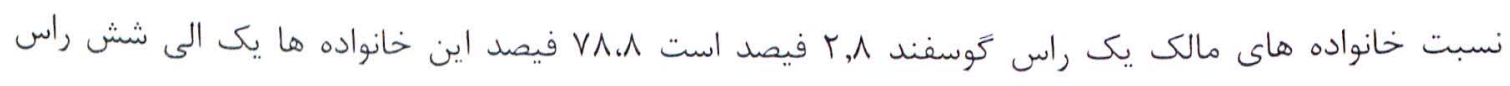

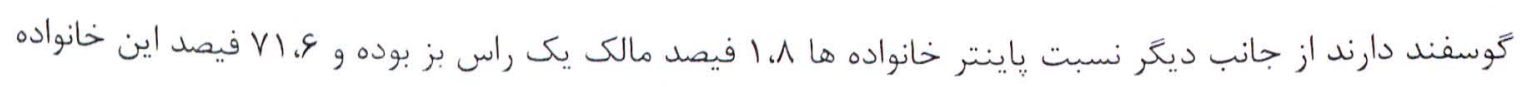
هاى الى شش راس گوسفند دارد. 
نسبت يايين خانواده ها داراى يكى راس اسٍ، مركب يا قاطر بودند زيرا بسيارى ساحات در كابل توسط وسايط موتوردار قابل دسترسى است. بسيارى ازين خانواده ها ه، بو فيصد مالك صرف يك يا دو اسب يا مركب است. از جانب ديكّر يرورش مرغ خانگى معمول ترين فعاليت در بين هانواده ها ميباشد كه به يرورش مواشى و طيور مى يرداختند اكثر خانواده ها مرغ را براى غذا برورش ميدهند جاييكه Y، Y فيصد خانواده ها كمتر از ه مرغ خانكَى را يرورش ميدهند. يك نسبت كوجك خانواده ها مرغابى يا فيل مرغ برورش ميدهند و، · فيصد نوع سرولت تشناب

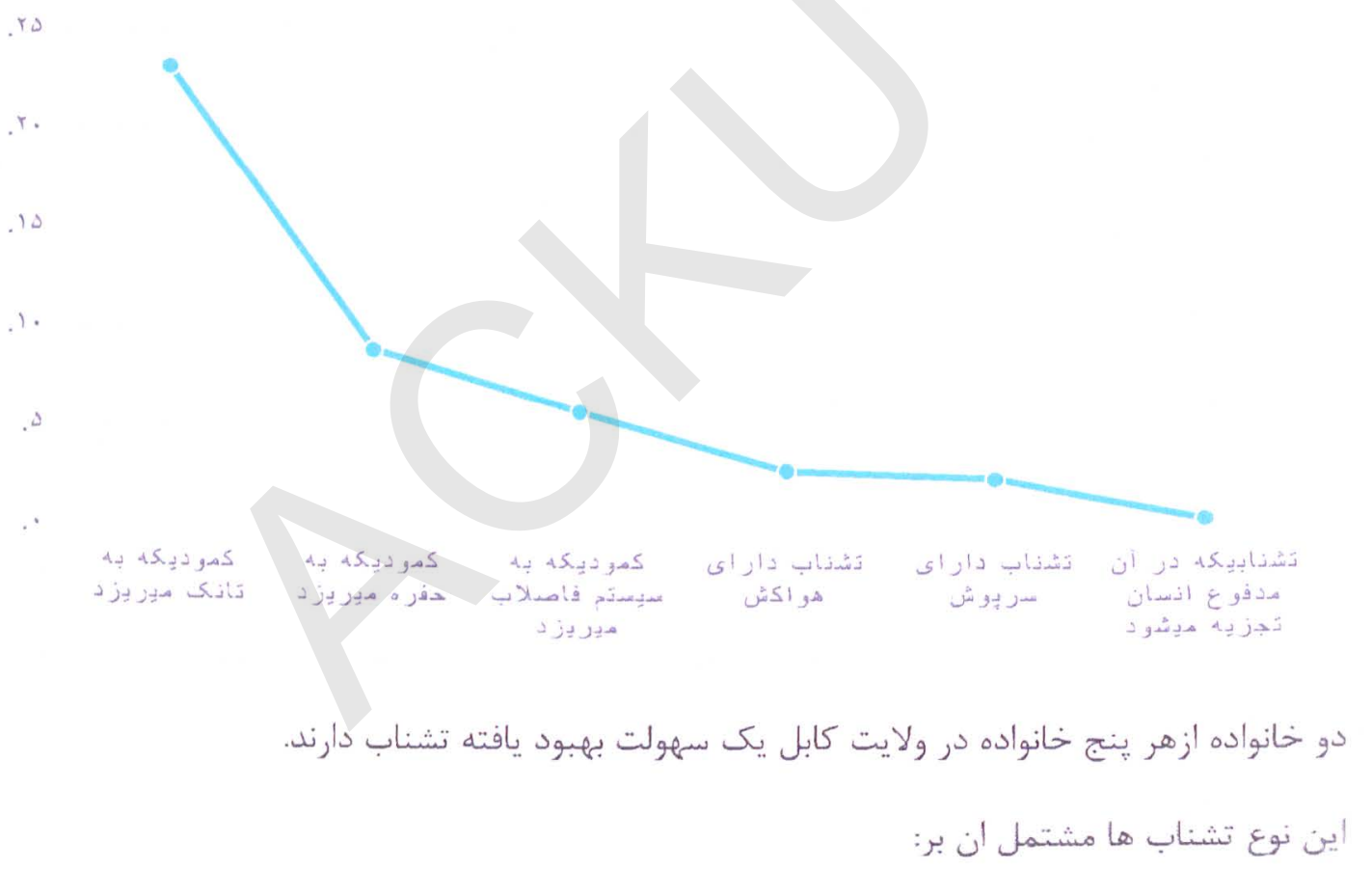

كموديكه به تانك ستتيك مى ريزند ז، بr درصد، كموديكه به حفره ميريزد 9،1 فيصد، كمود كه به سيستم فاضلاب مى ريزد A،ه فيصد، تشناب داراى هواكش ج،r فيصد، تشناب داراى سريوش ه،r فيصد، و تشنابيكه مدفوع انسان در آن تجزيه ميشود ه، · فيصد بيشتر از نصف خانواده ها ولايت كابل ه، هاه فيصد از نوع تشناب هاى محلى استفاده ميكنند كه مدفوع بالاى زمين ذخيره شده وقتا فوقتا تخليه ميكردد. ( استراتيزى صحت محيطى. (1) (1) 


\section{تعداد اطاق در واحد مسكونى كه در اختيار خانواده قرار دارد و تعداد اطاق هاى خواب}

مسكن بيش از حد مزدحم مى تواند بر صحت جسمى و روانى اشخاصيكه در آنها زندكى ميكنند و انكشاف اطفال اثرات منفى داشته باشد.

اطاق هاى كه اطاق مسكونى هنداشته شده اند عبارت اند از اطاق هاى خواب، اطاق طعام، اطاق نشيمن، اطاق مطالعه اطاق خدمتكاران، آشيز خانه ها و تشناب ها منحيث اطاق محسوب نميشود. حدود ا،Vا فيصد خانواده ها در ولايت كابل در واحد هاى مسكونى زندَى ميكنند كه صرف يك اطاق داشت، در

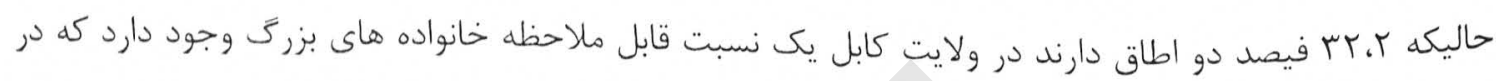

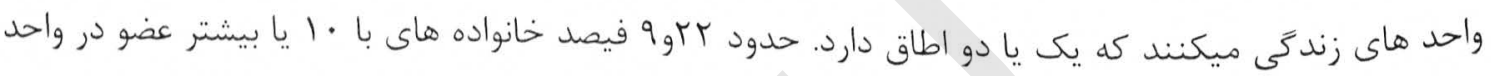

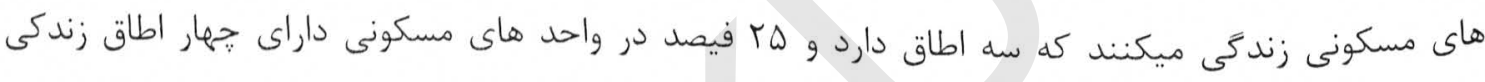
ميكردند. صرف 9، 19 فيصد خانواده اهى داراى ·ل عضو يا بيشتر از آن در واحد هاى مسكونى زندكى ميكنن كه شش يا بيشتر از شش اطاق دارد( استراتيرى صحت محيطى. بوجr )

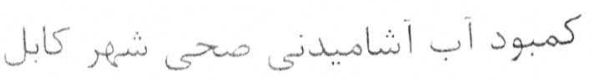
شهر كابل كه مركز كلتورى سياسى ادارى اجتماعى تجارتى و فرهنَّى بوده كه در ابتدا آغاز زندكى در كابل باشندًان در نزديكى سواحل درياى لوكر كه دارى زمين هاى زراعتى حاصل خيز و آب بوده و بعداً در تبه زمرد اولين هسته كابل را كَاشتند كه از همين تيه زمرد جنوباً شمالاً شرقاً غرباً انكشاف يافته و دكابل امروزى از آن مشتق شده است. در ابتا كابل خند صد خانه وار بوده كه بعداً انكشاف نمود بايد تذكر شد كه شهر كابل بدون كدام يلانرشهرى از همان آغاز زندكى شهروندان انكشاف كرده بعداً در زمان شاه امان اله كه ماستر يلان شهرى توسط يكى از كمينى ها ساخته و طرح و ديزاين كردد كه نشد.

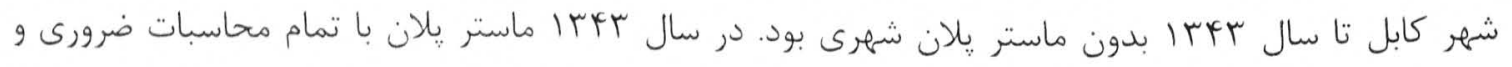
خدماتى ابتدايى شهرى براى . •1 هزار نفر طرح ديزاين و تر تيب شد در همان مقطع زمانى آب ضرورت شهروندان 
كه آب هاى سطحى نيمه سطحى و آب دريايى كابل كه در زراعت استفاده ميشد براى شهروندان همان وقت كفايت ميكرد بايد متذكر شد كه آبهاى متذكره بدون اينكه از كدام تصفيه خانه بخذرد و يا تصفيه كردد مستقيماً در اختيار شهروندان قرار ميكَرفت جون آبهاى متذكره ظاهراً پاى و شفاف به نظر ميخورد. كه در همان مقطع زمانى كه در شهر ككابل . ·ـ هزار نفر زندكى ميكرداز هر پنج نفر يك نفر در كابل به سيستم قسماً فرسوده آب آشاميدنى دسترسى داشت. كم اكثراً شهروندان شهر كابل از آبهاى جهباهاى نيمه عميق آبهاى جذب باران و برف و يا تانكر هاى آب وابسته بودن البت منابع آب به كَونه فزاينده مورد استفاده بيش از حد قرار كَفته و الوده ميشود اي ن امر به صحت مردم لطمه زده بويزه به كودكان مصاب به امراض كوناكون ميشود. انكشاف سياسى و اقتصادى نيز از آن متضرر ميشود دز شهر كابل مشكل تنها شكل كمبود آب نيست بلكه در نل

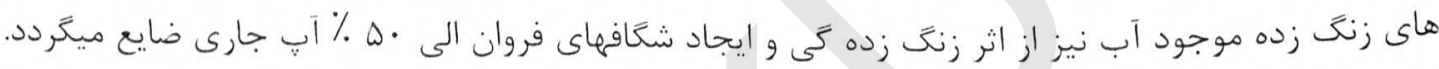
عدم سيستم كاناليزاسيون در كشور، نبود سيستم منظم زباله هاى شهرى، آلوده گى محيط ريست و نبود فرهنگ شهرى عواملى اند كه تاثير مستقيمم بالاى آب آشاميدنى دارند. هر خند كاسه هاى آبى كاسه هاى آبى در شهر كابل آلوده نيست اما در معرض خطر قرار دارد ( راديو ازادى .هوجr|)

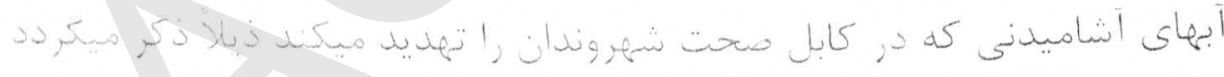

$$
\begin{aligned}
& \text { حفر جاهاى جذب فاضلاب } \\
& \text { حفر خاهاى نيمل ارضى } \\
& \text { استفاده از آبهاى سطحى }
\end{aligned}
$$

حفر جاهاى آب بصورت غير فنى و تخنيكى بدون ديتاى تحقيقات هايدور جيولوجى آبهاى زيرزمينى را ملوث ساخته كه باعث امراض گَوناگون شده اس. 


\section{حفر جاهاى عميق غير معيارى}

فروش آبهاى نيمه سطحى و زير زمينى كه از طرف اشخاص و افراد غير مسًّل به شهروندان شهر كابل تهيه

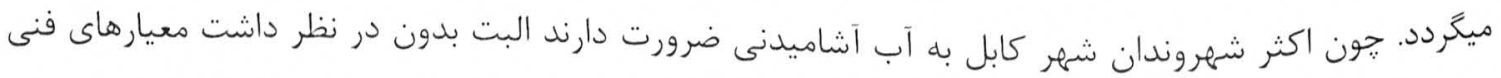
קاه فنى حفر شده و بخاطر ير كرن جيب هاى خويش آب آنرا به همشهر يان خويش به فروش ميرساند بايد كفت

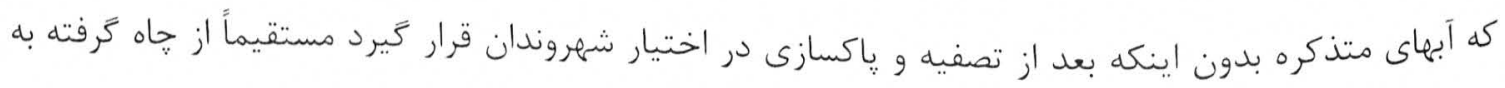
تانك ها رفته و به فروش ميرسد و شهروندان در مقابل آن يول تاديه مينمايند كه به عوض آن امراض راخريدارى مينمايد. يروزه اي آبرسانى شهر كابل كة تا حال موجود بوده كله از فر سودكى نيمه فياليت دارند

$$
\begin{aligned}
& \text { • بروزه آبرسانى كارته يروان } \\
& \text { شبكه آبرسانى قلعه فتح اله } \\
& \text { تاسيسات آبرسانى يروان سوم } \\
& \text { شبكه آبرسانى وزيرآباد } \\
& \text { شبكه آبر سانى شاه شهيد } \\
& \text { شبكه آبرسانى غرب بنجصد فاميلى } \\
& \text { بروزه آبرسانى افشار } \\
& \text { شبكه دوصد فاميلى } \\
& \text { شبكه آبرسانى رحمن مينه } \\
& \text { شبكات آبرسانى كارته r ب } \\
& \text { هروزه آبرسانى بى بى مهرو }
\end{aligned}
$$


شبكه هاى متذكره ساليان قبل احداث كرديده اكثراً استهلاك شده و يا نيمه كاره ميباشد به اين معنى كه آب مورد نياز را تهيه نميتواند و فعلاً قابل استفاده نيست و نميباشد. از طرف ديكًر نبود كاناليزاسيون شهرى شهر كابل آبهاى زير زمينى را نيز ملوث ميسازد و باعث بوجود آمدن امر اض گرديده است. ندانستن محاسبات منسوبين و مسولين سكتورى در تهيه آب آشاميدنى نيز ايجاد مشكلات نموده است . و همجنان منسوبين درجه اول وزارت شهرسازى با شاروالى كابل بدون اينكه بعد از سروى و محاسبات دقيق در

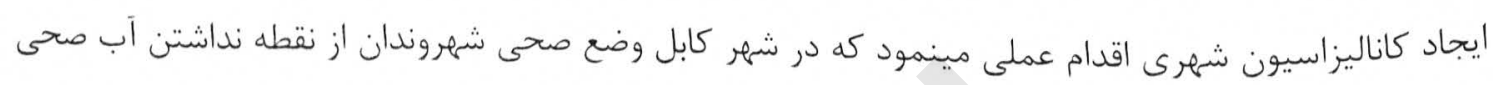
آشاميدنى به طور نسبى مرفوع وتضمين ميكر دد.

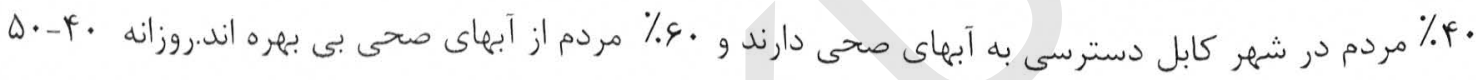

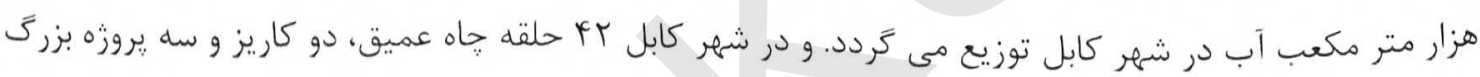

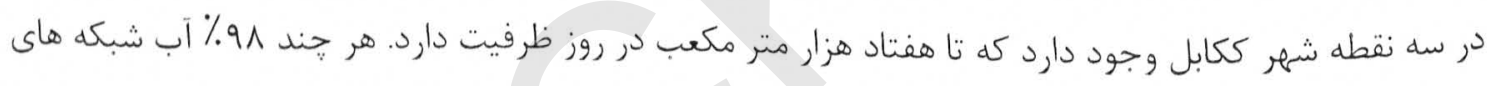
ما پاك است، دز صورتيكه در مسير راه ملوث نشود. با تاسف حاه هاى سبتيك، كثافات شهرى و رسوبات به آبهاى زيرزمينى، تشناب هاى بدرفت منازل، كثافات درياى كابل همه و همه در آلوده شدن نقش بارز دارند اين يك خطر جدى است، اكر اين حالت تا ـا سال ديكر دوام ي ييدا كند. ما آب صحى خود را كاملا از دست خواهيم داد. اعمار خانه هاى خود سر در نزديك ذخاير آبى، به خصوص در كارته نو در تنفس را بر مردم تنغ ساخته و آن را را در محاصره قرار داده است. در شهر كابل در قسمت نمرات رهايشى و بلند منزل ها تخطى هاى صورت كرفته قسميكه در ساخت آنها از خاه هاى جاذبه كار كر فته ميشود. با آنكه تمام بلند منزل هاى كابل با حاه هاى سيّك و حايق كارى مجهز مى باشند ولى تخليه آن براى محيط زيست خوب نيست. ( استراتيرى صحت محيطى.بوجr () 
موجوديت عازات مضر؛ مواد سربى و •؟٪ مواد غايطةً انسانى شهروندان در هوا جيزيست كه با باريدن باران اين عناصر به زمين گِايُين آمده و در نتيجه آبهاى روى زمين و زير زمينى را آلوده ميسازد. حدود . v\% آلودگى هواو و آب ناشى از ترافيك و كَازات مضره سرب هاى مخلوط به تيل است ه باعث امراض كَوناكون ميشود. به تعداد • r فابر يكه آب معدنى در سرتاسر كشور راجستر شده كه با فابريكه در شهر كابل و متباقى در شهر هاى بزرى كشور به توليد آب صحى معدنى مييردازد و اين آب مورد استفاده خارجى ها، انجو ها، موسسات وغيره قرار ميكَيرد. اما شكابت از آن است كه كَفته ميشود برخى از اين فابر يكه ها از آب اى ملوث نل هاى شهرى ير كارى كرديده و به مردم عرضه مى كردد. اكثر فابر يكات توليد آب دعدنى بدون جواز فعاليت دارد كه بايد آب آنها جكى و كنترول گر دد و براى لابراتوار نزد آبرسانى مراجعد نمايد كه متاسفانه جنين نيست حتا بعضى از فابريكه ها بدون هيج كونه تصفيه و تبخير از آب نل ها در بوتل ها جاسازى نموده و به فروش ميرساند. سالانه در سرتاسر كشور • •ه- •و هزار طفل از اثر اسهالات، كولراو آميب و محرقه كه ناشى از آشاميدن آب غير صحى مى باشد تلف ميشود. تا هنوز روشن نشده است كه كدام نوع مواد كيمياوى در آب غير صحى وجود دارد كه سبب مرى و مير اطفال ميشود. آبهاى سطلحى در شهر كابل شهر كابل داراى اقليمى نسبتا خشك است و مجموع بارش سالانه آن كمتر از ميزان تبخير است. ولى هر سال با شروع فصل بهار و خزان ميزان بارندگى ها افزايش ييدا كرده و به دليل نبودن مديريت درست آبهاى سطحى، شاهد تصاويرى ناب و بديع هستيم. تصاويرى كه شايد در كمتر پايتختى از جهان به خشمى آيد

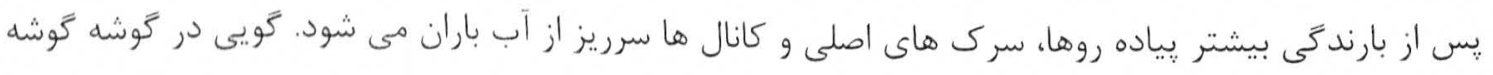
شهر درياجه هايى تشكيل شده است. هنين وضعيتى نه تنها باعث مشكلات بسيارى در جريان كارهاى روزمره ساكنان شهر شده، بلكه باعث گَترش سريع تر انواع آلودگى ها و امر اض مى شود. پس از ختم بارندگى نيز با

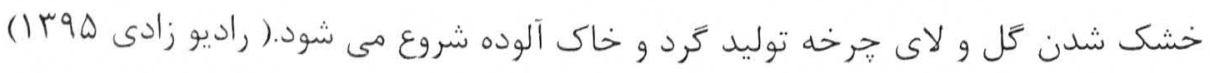




$$
\text { زون بندى مدير يت آبهاى سطحى نر كابل }
$$

بدنه اصلى سيستهم زهكشى آبهاى سطحى در شهر كابل را ميتوان به موارد زير تقسيم كرد

$$
\text { در بخش شمالى شهر كانال وزير آباد }
$$

$$
\text { در بخش غربى شهر درياى يغمان }
$$

$$
\text { جنوب غرب و مركز شهر درياى ميدان }
$$

$$
\text { مركز و شرق شهر درياى كابل }
$$

$$
\text { و جنوب شرق درياى لوّمر }
$$

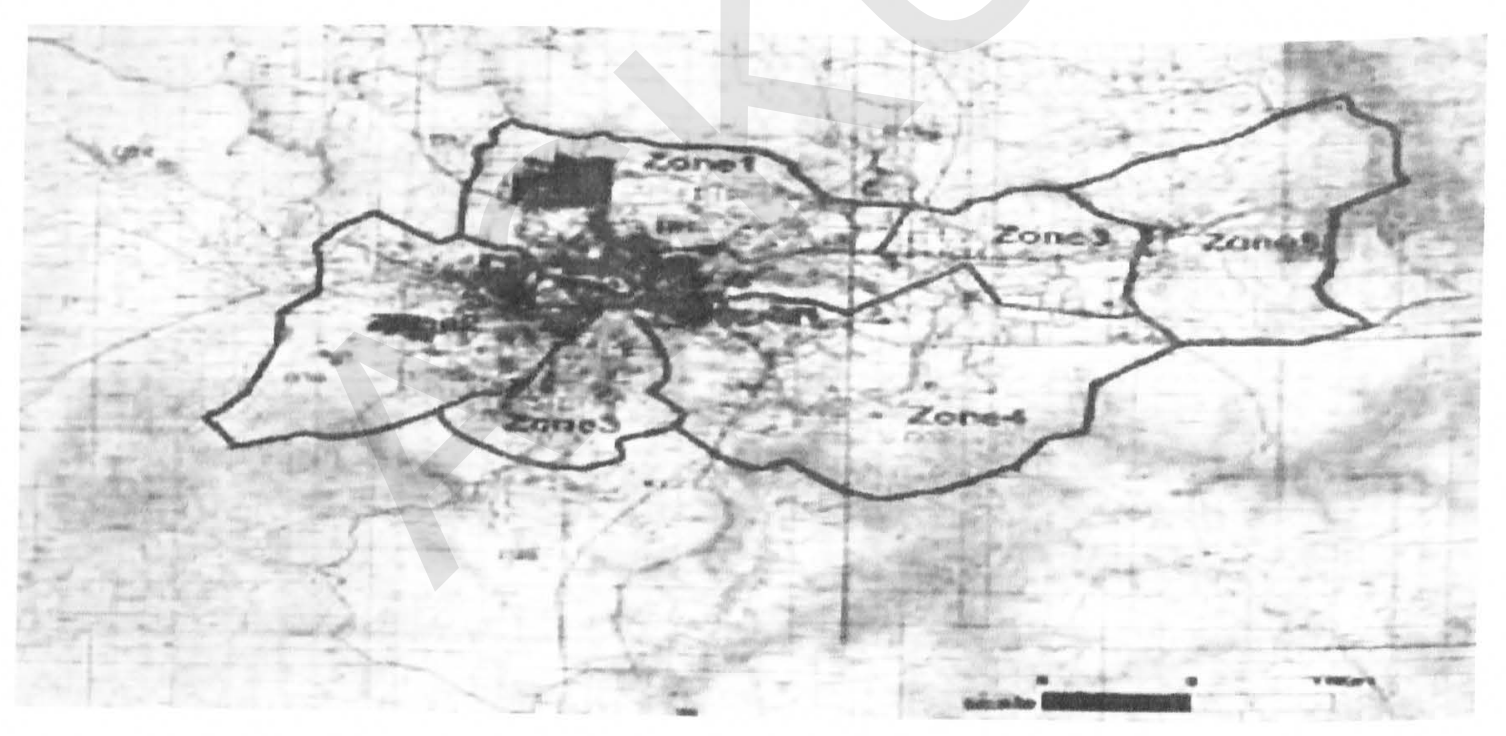

بنابراين ديده مى شود كه با وجود جندين دريا و همجنان كانال وزير آباد در قسمت شمالى شهر كابل، كنترل و هدايت آبهاى سطحى در شهر كابل موضوع جندان بِيجيده أى نيست. در واقع شهرهاى بسيار كمى از خنين امكان طبيعى مناسبى براى مديريت مناسب آبهاى سطحى و جلوكيرى از مشكلاتى مانند سيلاب و ...برخوردارند. بخصوص كه ميزان بارندكى در شهر كابل نيز در حدود . .ب ميلى متر در سال مى باشد كه رقم بالايى محسوب 
نمى شود. در نتيجه مى توان گفت كه علت اصلى مشكلات موجود در مديريت نادرست آبهاى سطحى در شهر كابل و همجنان عدم وجود زيربناهاى مناسب مى باشد. ( بى بى سى فارسى.بوب |)

• آ آبهاى زيرزمينى كابل غير صحى است مسولان اداره حفاظت از محيط زيست افغانستان از وضعيت آلوده و غير صحى آب هاى زيرزمينى شهر كابل نكَران است و ميكويند كه هم اكنون ٪ آبهاى شهر كابل غير صحى ميباشد در برخى ساحات فيصدى موجوديت باكتريا ها يا مواد كمياوى زياد است.

عدم رعايت مسايل صصجى در حريمم منابع آب، ورود فاضلاب شهرى و يس آبهاى كشاورزى به منابع آب، نبود سيستم كانال هاى آبرسانى، نبود كاناليزاسيون، غير معيارى بودن خاهاى فاضلاب، وجود زباله ها و كثافات در شهر كابل، نبود آب در دريايى كابل، تراكم نفوس و استفاده اعظمى كود كيمياوى از عواملى اند كه سبب آلوده شدن آبهاى زيرزمينى شده است در برخى از محلات شهر كابل آب تا عمق كمتر از أو ه مترى بيرون ميشود ولى اين آب آلوده است و باعث انتقال امراض باكترياى ميشود.

به كزارش خبركزارى آوا ، كارشناسان محيط زيستى بز اين عقيده اند كه همه ساله سطح آبهاى زيرزمينى كم ميشود و تا خند سال ديخر كمبود آب آشاميدنى در شهر كابل به معضل بزرى و خطرناك مبدل ميشود. در واقع با ايجاد سيستم معيارى آبرسانى، كاناليزاسيون مى توانيهم از افزايش امراض جلوكيرى كنيهم اما با توجه به وضعيت اقتصادى و شرايط فعلى جامعه ميتوان با حفر خاهاى بسيار عميق و استفاده از كلورين تا حد قابل ملاحظه اى از مبتلا شدن به بيمارى هاى گَونائون جلوكيرى به عمل آوريهم. در حال حاضر، اكثر مردم كابل از آبهاى زيرزمين استفاده ميكنند. ( بى بى سى فارسى.بوr I) استفاده از آبهاى زيرزمينى كابل همم اكنون از لحاظ مى و كيفى در مرحله بحر انى رسيده است. از طرف آب حاه ها وز به روز پايين تر مى رود اين امر سبب ميشود تا شهروندان براى جبران كمبودآب، خاه هاى عميق تر حفر 
ميكنند كه اين خود روند كم شدن آب را سرعت ميبخشدو حجم استفاده از آبهاى تجديد بذير را افزايش ميدهد

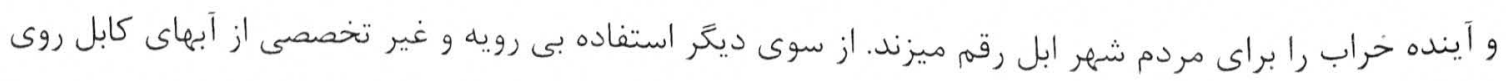
وضعيت زيست محيطى شهر اثرات مخرب و نامطلوبى بجا كَذاشته و دور نماى زندَّى را در اين شهر در تاريكى و

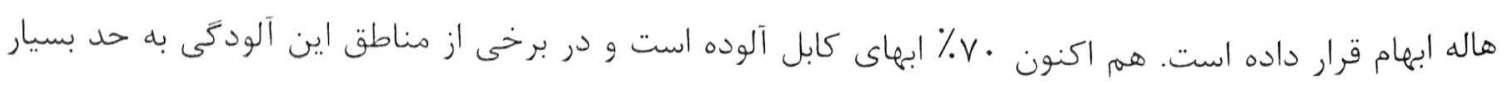
بالاو خطرناى رسيده است آبهاى آلوده در شهر كابل به دليل دارا بودن مواد مضر شيمايى و فلزات سنَّين، منشا انواع آلودَى ها در اين شهر كرديده است و به سلامتس شهروندان آسيب زده است بر مبناى تحققات انجام شده بيش از r r امراض كه در كابل وجود دارد منشاى آن آبهاى غير صحى مى باشد. بنابر اين آبهاى كابل در حال حاضر با دو تهديد جدى روبرو مى باشد.

$$
\text { - - - بآلودگى - بين رفتن سطح آب زيرزمينى }
$$

افزايش بى رويه جمعيت، نابسامانى و بى نظمى در مصرف آبو حفر خاهاى عميق، كاهش بارندكى و مسدود شدن ركه هاى جذب آب در زمين به دليل خشك سالى ها و از بين بردن فرش نباتى و..... از مهمه ترين عوامل بايين رفتن آب هاى زيرزمينى در شهر كابل به شمار ميرود.

از سويى همم به باور كارشناسان ايجاد مخازن زيرزمينى به شكل غير فنى براى مواد نفتى نيز يكى ديكر از دلايل

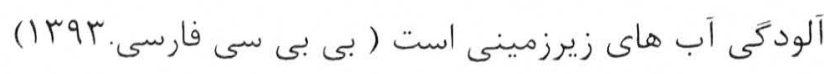


دريا كابل، كثيف ترين و مهلم ترين منبع آلودكى آبهاى زيرزمينى به شمار ميرود و ه اكنون تشناب اكثريت خانواده ها به اين دريا منتهى ميشود، آبهاى سطحى و درياها منبع تغذيه آبهاى زيرزمينى است ولى دريايى كابل در كنار

$$
\text { موارد ديخًر از مهم ترين منبع آلودكى آبهاى زيرزمينى اين شهر به شمار ميرود. }
$$

در شهر كابل بسيارى خانواده ها براى دفع فاضلاب خود خاهاى بدرفت را به شكل غير فنى حفر مى كنند و شمارى هم فاضلاب شان را بع ضورت مستقيم از طريق جويجه ها به دريايى كابل منتهى ميكنند در بسيارى ناحيه هاى شهر كابل، زمانيكه يك جاه سيتيك حفر ميشود، خاى آن به زودترين فزصت فاضلاب را جذب ميكند.

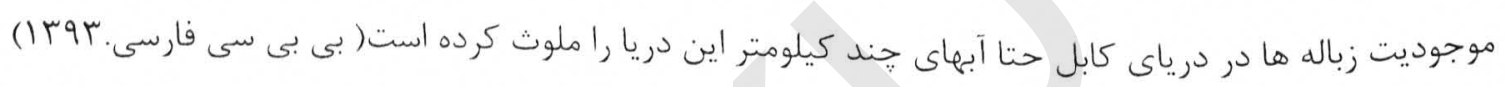

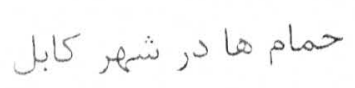
روزانه هزاران تن در شهر كابل، به حمام هاى عمومى مراجعه ميكنند،اما داكتران به دليل عدم مراعات حفظ الصحه، اين عمل را غيرصحى و مضر ميداننددر شهر كابل از سالما بدينسو در يهلوى حمام هاى نمره يى، دهما

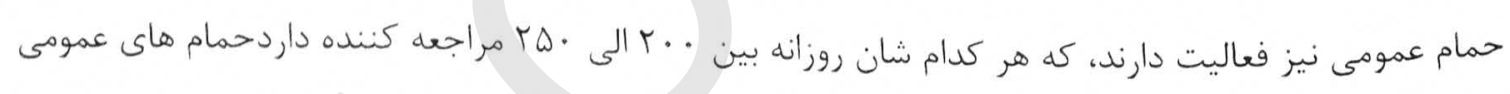
كه حمام هاى كَله يى نيز ناميده ميشود، داراى يك سالون بزرى مى باشد، هر سالون، معمولاً داراى دو حوض مى ديى باشد، كه يكى آب كرم و ديخرى آب سرد داردمردم در كنار ديوار سالون، كنارهم نشسته از حوض مشترك، آب ميخيرند و از آن براى غسل استفاده ميكنند همجنان در همجو حمام ها، افراد خاص به نام كيسه مال موجود مى باشند كه مردم را در مقابل يِيسه، جداكانه كيسه ميكننداين حمام ها خاه عميق سربسته دارند و با استفاده از واتر يمب، آب را به ذخاير حمام بالا ميكنندبا آنكه اكثريت مردم،در خانه هاى خود براى حمام تشناب دارند،اما به حمام هاى عمومى مر اجعه ميكنندمرتضى 19 ساله محصل سال سوم يوهن خُى فارمسى يوهنتون كابل، كه تازه از حمام حراغ على واقع قلعهُ فتح الله بيرون شده بود، كَت : "حمام هاى عمومى فضاى خوب دار ، خوب ״اك ميشويهم و خستخى را رفع ميكندمر تضى افزود كه در هفته لا اقل دو تا سه بار، از حمام عمومى استفاده وى با آنكه 
از نظافت عمومى حمام تا حدى راضى است، اما ميكُويدكه وسايل (سطل، تاملوت...) كه از آنها استفاده ميشود، كهنه و پاك نمى باشندمر تضى، علاوه ميكند كه گَ جه وى با خود كيسه مى آورد، اما اكثريت كيسه مالان، از يك كيسه براى هند تن استفاده ميكنندغلام حيدر كه ·r سال سن دارد و شاكرد يكى از فروشگاه ها در جادة ميوند است، ميكُويد كه در خانه حمام دارد،اما بخاطر كَم بون و رفع خستّى، هفتهٔ دوبار از حمام عمومى استفاده ميكندوى علاوه ميكند: "وقتى كه زياد خسته باشم، به حمام ميايمى و بدنم نرم ميشود و تمام خستگى ام رفع ميشود و سبك ميشوم غلام حيدر مى افزايد كه گرحه نظافت اين حمام تا حدى خوب است، اما شمارى مردم از وسايل (ليف، كيسه، سنَ پا) مشتركاً استفاده ميكنند وى ميكَويد كه استفاده اين وسايل به شكل دسته جمعىخوب نيست و بايد هرشخص، از وسايل شخصى خود استفاده نمايد .قرار معلومات خير محمد صفدرى رئيس تنظيم ماركيت هاى شاروالى كابل، در اين شهر بع باب حمام عمومى و سقاوه (انفرادى)، رسماً فعاليت دارند، كه VV باب آنها، حمام عمومى و باقى شان انفرادى است محمد ظلاهر D ساله،از مدت سه سال به اينسو، حمام جاده ميوند را كه حدود •^ سال قدامت دارد، به اجاره كرفته استوى ميكويد كه اين حمام، روزانه از أ عصر الى

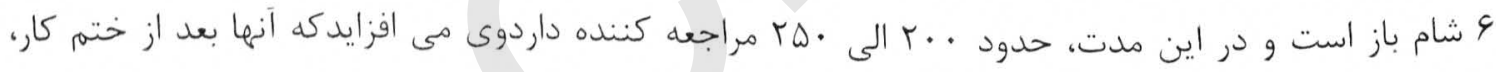
حمام و وسايل حمام را با يودر رختشويى شستشو ميكنندظاهر،خاطرنشان ميكند كه اين حمام، علاوه بر اينكه عمومى است، · r اتاق نمره نيز داردهرشخص براى حمام كرن كه شاميو و صابون از خود داشته باشد، ·r افنانى

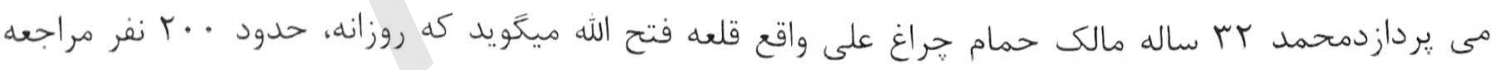
كننده دارد وى علاوه ميكند كه آنما حمام را بعد از ختم كار با آب گَم يودر شستشو و مايع ديتول مى شويند با آنكه حمام هاى عمومى، علاقمندان خود را دارد،اما شمارى از داكتران، به دليل عدم مراعات حفظ الصحه، اين حمام ها را غيرصحى و مضر به صحت ميدانند يوهنمل داكتر عبدالحى ولى متخصص امراض جلدى، استفاده از وسايل عمومى را انتقال دهندهُ مكروب ها ميداندقرار اظهارات موصوف، اكثريت مراجعين وى كسانى هستند كه در زير يكى جتر فعاليت دارند؛ مانند كلي هاى ورزشى و حمام هاى عمومى وى با بيان اينكة همجو اماكن، منبع انتقال انتان مى باشند،مى افزايد كه محلات مرطوب مانند حمامها و كليهاى ورزشى، مكانهاى خوبى براى رشد و 
انتقال انتانات از قبيل يورفورا و فنغسمها مى باشند به كَفته موصوف، اين انتانات باعث شيوع امراض جلدى مانند امراض التهابى و دانه هاى روى ميكَر ددولى علاوه ميكند: "در حمام ها حفظ الصحه كنترول نميشود؛ بسيارى از كسانيكة كه از جنين حمام ها استفاده ميكنند، به امراض جلدى مصاب هستند به كَفته موصوف، هر روز ديوارهاى حمام و وسايلى كه براى استفادئ عموم است، بايد با ديتول شسته و ضد عفونى شوندوى مى افزايد: "بايد ليف و كيسه براى يك نفر استفاده شود، زيرا يكى از راه هاى انتقال انتان، همين ليف و كيسه هايى اند كه از آنها براى קندين تن استفاده ميشودبا آنكه داكتران، حمام ها را مركزى براى انتشار مكروب ها ميدانند،اما داكتر سلطان محمود دوران آمر رياست حفظ الصحة محيطى وزارت صحت عامه ميكُويد كه مامورين اين رياست، همه روزه نظافت حمام ها را كنترول ميكنندوى در اين مورد كَفت: "يرسونل ما در نواحى مختلف شهر كابل توظيف هستند تا هر روز، تمامى حمام ها و سقاوه ها را از نظر حفظ الصحه بررسى نمايندداكتر دوران افزود كه وزارت صحت عامه، در مورد حفظ الصحة حمام ها، لايحه r T ماده اي دارد و تمام حمام ها مكلف اند تا مطابق آن لايحه، خود راعيار سازند وكرَنه با همكارى شاروالى، جريمه و يا مسدود خواهد شدوى علاوه كرد در اين لايحه آمده است كه كار كنان حمام ها، بايد كارت صحى وزارت صحت عامه، جِن منظم، كلاه و ماسك داشته باشنداما در اكثريت حمامها، اين لايحه مراعات نمى گَردددوران ميكَويد كه آنها بعد از بررسى حمام ها، رابور خود را به شاروالى كابل ميدهند و اين اداره، آنها را جر يمه ميكنند، و يك حمام، مبلغ .. . افنانى جريمه شده استبر اساس معلومات

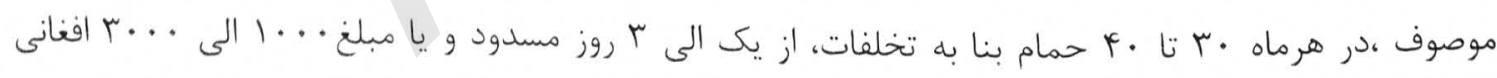
جريمه ميشوند( استراتيزى صحت محيطى.بوr () ) عوامل آلوده شدن آب هاى زير زمينى خند عامل عمده در راستاى آلودگى آب وجود دارد عدم موجوديت كاناليزاسيون افزايش حفر حاه هاى خود سر 
افزايش خاهاى سيتيك در نزديك و حتا داخل شبكه آبرسانى كه مخرش كاز ايتان و ميتان كه عامل

$$
\begin{aligned}
& \text { اصلى آلودگى آب است ميباشد } \\
& \text { بلند رفتن جمعيت كابل } \\
& \text { مديريت ناسالم }
\end{aligned}
$$

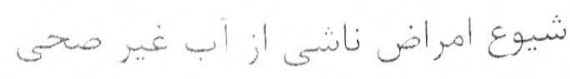

با شروع فصل كرما بيش از • • ٪ از مريضان مراجعه كننده به شفاخانه ها كسانى اند كه در نتيجةً استفاده از آب غير صحى مريض شده اند بيشترين مريضان كه به شفاخانه هاى انتانى مراجعه ميكنند مصاب به اسمالات ميباشن كه ناشى از استفاده آبهاى غير صحى و غذاى ملوث است. آلودكى آب هاى زير زميينى باعث امراض انتانى مانند كولرا، آميب يا زيس و توبر كلوز.... ميشود،( سيد جld (1)

$$
\text { زباله ها در شمر كابل }
$$

شهر كابل كه حالا نزديك به ينج ميليون نفر را در خود جا داده است، به شهر ير ازدحام تبديل ترديده است. ازدحام بيش از حد در شهر كابل منجر به آلوده گى محيط زيست در اين شهر گرديده است. وجود كثافات و دود ناشى از تردد وسايط در شهر كابل باعث به وجود آمدن بيمارى هاى جون نفس تنكَى، درد سر م است. ازدحام ترافيكى، وجود موتر هاى كهنه، استفاده از تيل هاى بى كيفيت نيز در آلوده سازى آب و هواى كابل دست نداشته

اما تعدادى از باشنده كَان كابل، علت ديخرى را يِيش مى كشند، آنان مى گويند وزارت مخابرات و شركت مخابراتى افغان تيلى كام، اطراف برخى از سرك ها را كنده اند، و دوباره ير نكردند كه اين خود در به وجود آوردن كل و كند.

$\varsigma^{\circ}$ كمى ى در شهر كابل مردم كثافات خود را روى سرى ها مى اندازند، بلكه بايد در زباله دانى ها انداخته شود. 
وجود كثافات در شهر كابل باعث توليد بوى بد مى گردد و اين خود در تنفس مشكلات را خلق مى كند. در كو جه ها و سرى ها زباله به جشهم ميخورد كه باعث توليد بوى بد واز منظره شهرى ميكاهد. از يك سو بادهاى خزانى و زمستانى اين كثافات را به هر سو يراگنده ميكندو مردم را ازيت ميكند .يكى از علت هاى حالت فعلى

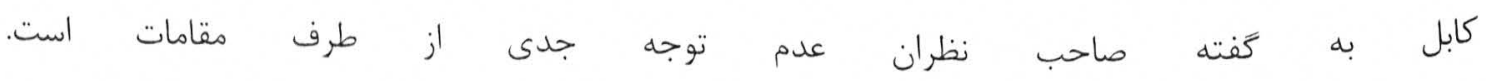
در مناطق محتلف شهر كابل تعمير هاى مجلل آباد شده است، اما كَذشتن از مقابل اين ساختمان ها، در زمستان

$$
\text { به كشتى و در تابستان به جرات فوق العاده ضرورت دارد. }
$$

كثافات در شهر كابل از توان رياست تنظيف شهر كابل بالا ميباشد، اين رياست با داشتن ها الارى قادر است روزانه حدود • اV IV تن كثافات را در شهر كابل جمع آورى نموده به خارج از شهر انتقال دهد اين در حالى است

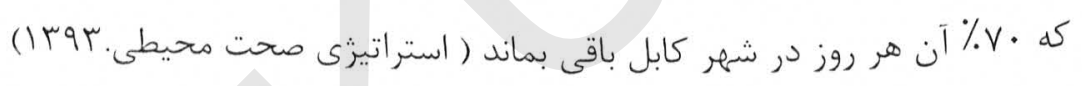

وضعيت امنيتى مشكل ديخر را در راستاى به كار كماشتن تعداد بيشتر كامندان و وسايل براى رفع اين مشكل ايجاد نموده است. در اين راستا خريدارى وسايط نقليه جديد و به كار كماشتن بيشتر تنها مشكل نيست كه اين رياست به آن مواجه است.

با عبور و مرور باشندًَان ولايت دور و نزديك در شهر كه باعث توليد مقدار بيشتر كثافات ميگردد خود پالش ديخريست كه اين رياست به آن روبرو است. با مخلوط شدن كثافات با هوا باعث رخش امراض مانند آفات جلدى انتانات و اسمالات به ساير مناطق ميكُردد. به دليل بى توجهى مسئولين و مردم، حجم كثافات و آلودگى ناشى از آن جان هزاران باشنده شهر كابل راتهديد S.

تراكم كثافات، جارى بودن آب هاى كُنديده در كوجه و پس كو خه ها، خر ابيهاى جاده و عملكرد هاى خود سرانه برخى از داكتران در قبال مريض از مواردى هستند كه هم اكنون سلامتى جان هزاران باشنده شهر كابل را تهديد كند. 
باوجود اينكه شهردارى كابل هموار0 روى ياكى شهر و بخصوص دريايجه اين شهر تاكيد داشته اما هيج رويكرد مثبتى در اين خصوص ديده نمى شود طوريكه هر روز بر حجه كثافات و كنديدكى هاى دريا، كوخه ها و يس كوجه در واقع شهردارى مسئول جمع آورى كثافات و انتقال آن از ساحات مسكونى به خارج از شهر است كه جنين كارى با امكانات كمى صورت مى كَيرد، اما متاسفانه مردم در اين باره كم توجه هستند، كثافات و اشغال هاى روز مره همه ساله در فصل بهار و تابستان بوى كَند كثافات در داخل دريا و كوجه ها مردم را اذيت مى كند. برخى از مردم براى بدست آوردن يول و حَذران زندَى اقدام به يخت غذاهاى غير استندرد آن هم در فضاى باز مى كنند كه اين امر باعث تراكم كثافات و مخس ها و و آلودَى مواد خوراكى مى شود. وجود معتادين در شهر كابل به خصوص در منطقه يل سوخته را نغران كننده است و وجود شمارى از معتادين به

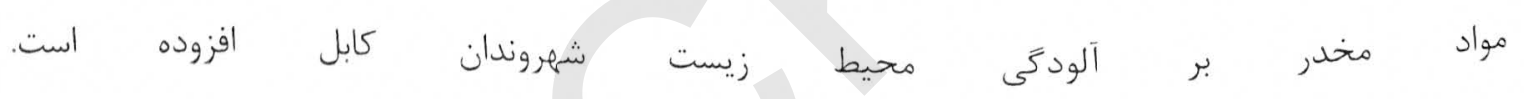
اگر وضع به اين منوال بيش برود و دولت توجه جدى نداشته باشد به زودى كسانى كه در منطقه يل سوخته مشغول كار و فعاليت هاى روز مره هستند، بيمار خواهند شد. ( استراتيزى صحت محيطى. rوب () ) تشناب ها در شمر كابل كمبود تشناب هاى عمومى در شهر كابل، يكى از مشكلات اجتماعى است كه بيشتر مردم بخصوص آنعده كسانيكه از مناطق دور و ولايات به اين شهر مى آيند با مشكل مواجه مى شوند.

هر جند شاروالى كابل از ساختن جهل تشناب در حومهء شهر ياد كرد، اما قسميكه ديده ميشود، با اين تعداد نفوس كه اكنون در شهر كابل زنده گى مى كنند، خهل تشناب كافى نيست. يكى از منظرههاى كه در קايتخت افنانستان خشم هر بينندهى را به خود جلب مى كند و در كمتر جايى از جهان مى توان با اين گونه منظرهها روبهرو شد، نقاطى در شهر اند كه افراد در مقابل جشمان مردم، بدون هيج گَونه 
مراعاتى كنار ديوارها، ادرار مى كنند. اين كار تقريبا براى همهى شهروندان عادى شده است؛ تا جاى كه حتى اكر كسى را ببينند كه دست به اين كار مىزند، بى خيال از كنارش مى كذرند. ( استراتيزى صحت محيطى.بوب () طبق آمارهاى موجود كه از سوى نهادهاى دولتى و خارجى ارايه شده است، شهر كابل با جمعيت بيشتر از لميليون نفر، ير نفوسترين شهر افغانستان است. در همين شهر رِج ميليونى، شهردارى كابل تنها •† باب تشنابهاى عمومى ساخته است كه همانها نيز خيلى مورد استفاده مردم قرار نمى كيرند. با توجه به تمام نفوس شهر كابل، يعنى براى هر •lf هزار نفر يك باب تشناب در يك نقطهى از شهر كابل ساخته شهه است كه در داخل هر تشناب عمومى رينج تا ده كابين وجود دارد. يكى از مشكلاتى كه بيشتر مربوط به اخلاق اجتماعى و فرهنَ شهرنشينى مىشود، موضوع آلوده نساختن فضاى عمومى كو خهها و خيابانهاست كه در افغانستان اين مساله اصلا رعايت نمىشود. ادرار كردن در كنار جادها، در محلات عمومى، در كنار ديوار خانههاى مردم، مكتبها و يا تاسيسات دولتى، اكر جزو از افتخارات اين مردم نباشل، كمتر از آن هم نيست.

در كنار اين، شهردارى كشورها معمولا در همآهنكَى با وزارتهاى آموزش و يرورش، فرهنَ و نهادهاى اجرا كننده قانون، مسووليت دارند تا برنامههاى را داشته باشند كه از يك طرف به مردم جكَونَى زندكَى در شهر را آموزش دهند و از سوى ديخَر، اجازه ندهند مكانهاى در شهر از سوى شهروندان ايجاد كردد، كه تبديل به تشنابهاى عمومى سرباز شود. يكى از اين مسووليتها، ساختن تشنابهاى عمومى معيارى با توجه به نفوس شهرهاست و آَاهى دهى به مردم كه بايد از اين تشنابها استفاده كنند. به كونه مثال در كابل، نقاطى وجود دارد كه مردم به جاى رفتن به تشناب شهردارى، در هند قدمى همين تشنابها در فضاى باز ادرار مى كنند؛ درحالى كه رسيدن به تشناب عمومى ده متر فاصلهى بيش نيست و اين مساله در كنار اين كه مسووليت اخلاقى شهروندان است كه بايد رعايت شود، 
شهردارى كابل نيز مسووليت دارد تا به مردم اين نكته را تذكر بدهد و يا در همكارى با وزارت داخله، آنان را جر يمه و يا مواخذه كند. ( استراتيزى صحت محيطى.rوr 1)

براساس قوانين شهرسازى مدرن در ساحات مسكونى و مزدحم شهرى، براى هر • له زن و طفل بايد يك تشناب عمومى ساخته شود. اين مساله براى مردان در هر .11 نفر يك تشناب عمومى طراحى شده است. مسوولان در وزارت شهرسازى مى كويند، بر اساس اين قوانين، اين آمار براى افراد معلول در هر • اهزار نفر يك باب تشناب مخصوص درنظر كَرفته مى شود.

در تمام شهر كابل، شهردارى تنها • ب باب تشناب ساخته است كه با توجه به نفوس بيشتر از ينج ميليون نفرى شهر كابل، براى هر • fl أ هزار نفر فقط يك تشناب عمومى ساخته شده است. حالا اگر فرض كنيم كه تشنابهاى ساخته شده به طور اوسط هر كدام ه باب تشناب داشته باشد كه بيشتر شان ندارند، شهر كابل براى هر .... هزار نفر يك باب تشناب وجود دارد.

بر اساس قوانين معيارى، شهرهاى مدرن در ساحات تجارتى و مزدحم در هر يك تا دو هزار متر مربع براى مردان يكى تشناب عمومى و براى زنان جهار تشناب عمومى بايد ساخته شود. ( استراتيزى صحت محيطى.بوب ا) ينجاه درصد آلودكّي ثنواى كابل از فاضلاب انساني است در هر كرام از مواد غايطه انسانى كه در هوا معلق مىباشد هزاران نوع ميكروب موجود است. با توجه به ارزيابىهاى انجام شده، • أ تا • له درصد از آلودگى كه در هواى شهر كابل وجود دارد، ناشى از مواد غايطه و ادرار انسانى مىباشد و بخش زيادى از بيمارىهاى يايتخت نشينان، ناشى از اين ميكروبهاى اند كه از فاضلاب شهرنشينان كابل به هوا بخش مى از يك طرف عدم آكاهى مردم و از سوى ديخًر ضعف نهادهاى دولتى مرتبط به صحت و سلامت مردم باعث شده

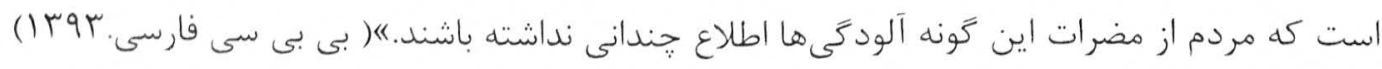


تشنابهاى كه در شهر كابل به صورت سنتى ساخته شده است و همجنين جوىهاى سرباز كه در آن فاضلاب جارى است، منبع اصلى بسيارى از آلودكى ها به خصوص آلوده شدن آبهاى زيرزمينى مىباشد. وزارت صحت عامه در نظر دارد از طريق رسانهاى جمعى و آموزش در مكاتب، آكَاهى مردم را در اين زمينه بالا ببرد. باتوجه به آلودَى شديد مواد غايطه و ِيشآب انسانى، تماس با اين مواد و يا تنفس اين گَونه مواد باعث به وجود آمدن انواع بيمارى هاى عفونى و ميكروبى نظير وبا، اسهالات، آميبيا و تبر كلوز (سل) شديد مىشود. بيشتر بيمارىهاى كه در شهر كابل باعث مرك و مير اطفال خرد سال مىشود بيمارىهاى عفونى و ميكروبى هستند كه از طريق تماس و يا تنفس هواى آلوده با مواد غايطه و يِشآب انسانى به وجود مى آيند، بيمارىهاى مثل اسهالات خونى كه يكى از عوامل اصلى مرك ومير اين كودكان هستند. ( بى بى سى فارسى.بوجبا) به صورت متوسط در شفاخانهاى خصوصى روزانه از هر ده نفر r الى ه نفر بيمار، به خاطر آلودكى هواى ناشى از مواد فاضلاب انسانى مراجعه مى كنند و در شفاخانهاى دولتى به دليل رايكان بودن هزينه ها، افر اد بيشترى مراجعه مى كنيد كه به طور ميانكَين هر روزه از هر ده بيمار ه الى 1 نفر از اين دست افراد مىباشند.

اما بيشتر اين مشكل ناشى از نبود فرهنَ شهرنشينى مردم و بى بروايى يايتخت نشينان به فضاى سالم و محيط پاكى ميباشد. شهردارى كابل در جاهاى كه رفت و آمد شهروندان زياد است، تشنابهاى عمومى ساخته است؛ اما نبود فرهنَ در ميان مردم سبب شده است كه هيج كسى به خود زحمت ندهد و از اين تشنابها استفاده نكنند. در شهر كابل، مكانهاى عمومى كه تبديل به تشنابهاى عمومى شده اند، بسيار زياد اند. افرادى نيز كه دست به اين كار مىزنند، از تمام اقشار جامعه هستند كه شامل كودكان، جوانان، يبر مردان و حتا در مواردى افراد شيك

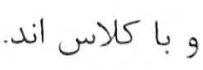
بدتر از همه كه بيشتر اين مكانها، در كنار مكاتب، ساختمانهاى ادارات دولتى و در مواردى حتا خانهاى مردم مىباشد.. ( بى بى سى فارسى.rوس (1) 
هر جند در خيلى از نقاط شهر كابل، با وجود اينكه تشنابها در خند قدمى اين دست افراد قرار دارند؛ اما آنان ترجيع مى دهند به جاى رفتن به تشنابهاى ساخته شده، در فضاى باز و در كنار درخت و يا ديوارى ادرار كنند. هر حند، تشناب هاى ساخته شده از سوى شهردارى نيز وضعيت جندان مناسبى ندارند. افر ادى براى پاى نحَمداشتن اين تشنابها يا موظف نيستند و يا اخر موظف هستند، وظايف شان را انجام نمى دهند.

\section{ضعف اخلاق و معضل فرهن} روانشناسان، به اين باور اند كه عامل اصلى ترويج و گسترش اين فرهنَّ، آهدن مردم از روستاها به شهر است كه با اين مسايل خيلى مشكل ندارند. حسن رضوانى، روانشناس به هشدار مى كويد: لاكثر باشندكان كابل كسانى اند كه از محيط روستايى به شهر آمده اند و هيج بدى در انجام اين عملشان نمىدانند و از طرف طبق آمارهاى روى موجود بيش از • V درصد مردم افغانستان بى سواد مىباشند. عدم آكَاهى در مورد فرهنَ شهرنشينى باعث شده است كه مردم مناسبات و فرهنكى كه لازمه زندكى در شهر است رادرك درست نكنند."

عدم درى درست مردم از هنجارهاى زندگى در شهر باعث شده است كه آنان درى عميقى از زندگى شهرى

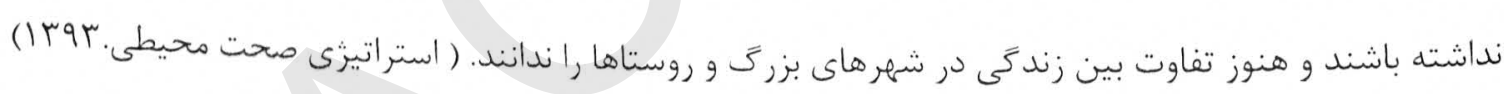
در مواردى حتا كسانى كه تحصيلات عالى دارند، نيز اقدام به اين كار مي كنيد و اين كار زوال فرهنَ و اخلاق در جامعه ما را به نمايش مى كذارد. 1 ا درصد نفوس كشور به يك نوع تشناب دسترسى دارند كه يك رقم بلند را در ميان كشورهاى همسايه نشان مى همد و اما هنوز هم 19 درصد نفوس كشور در فضاى باز رفع حاجت مى كنند. هر حند ا 1 درصد نفوس كشور به تشناب دسترسى دارند، اما تنها با درصد آن انكشاف يافته بوده و 9 درصد

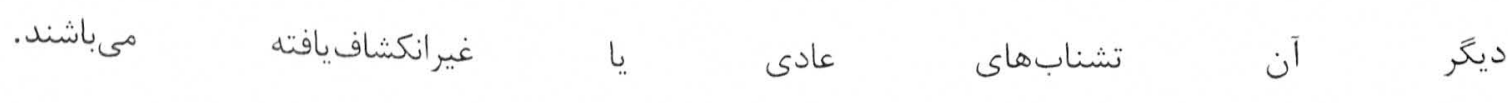
آقاى درانى افزود كه از سال II • ب بيش از ينج ميليون افنان به تسهيلات حفظالصحه دسترسى بيدا كردهاند و نفوسى كه در فضاى باز دفع حاجت مى كنند به \&,1 ميليون نفر كاهش يافته است. امروز فقط ه, f ميليون نفوس

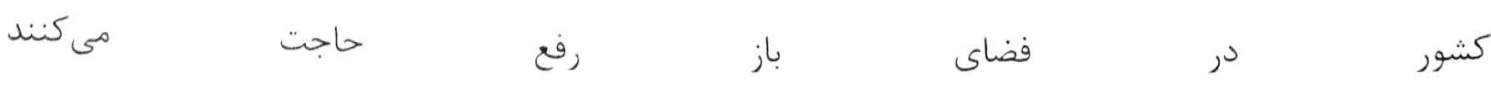


براساس از هر •ا نفر در افغانستان r نفر به تشناب دسترسى ندارند و در فضاى آزاد رفع حاجت مىكنند.

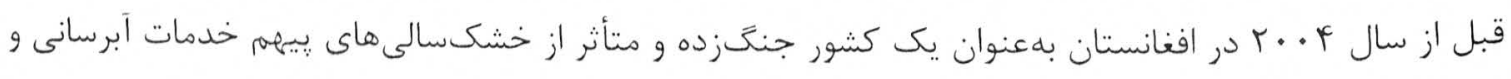

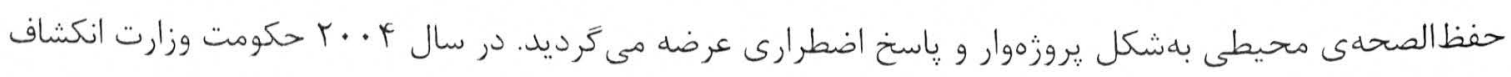
دهات را موظف نمود تا به عوض ارايهى خدمات آبرسانى و حفظالصحهى دحيطى به شكل يروزموار و پاسخ اضطرارى، به عرضهى خدمات برنامهوار اقدام نمايد( استراتيزى صحت محيطى.بوr () در بعضى مناطق دور افتاده كابل و حتى درمركز هنوز هم شمارى از مردم يس از رفع قضاى حاجت از كلوخ استفاده ميكنند. عدم موجوديت تشناب هاى عصرى، نبود سيستم كاناليزسيون، فقدان آكَاهى، عدم دسترسى مردم به آب و از همل مهمتر وضعيت ناكوار اقتصادى باعث شده است كه استفاده از كلوخ هنوز همم در كابل مروج باشد. با وجود آنكه استفاده از كلوخ يكى از كم هزينه ترين راه است اما معالجة امراضى كه از اين طريق به وجود يك شخص منتقل ميشود ميتواند يرهزينه باشد.

كلوخ ميتواند باعث انتقال امراض انتانى، ويروسى، نباتى، فنكَّى، باكتر يابى و امثال ان شود. كه اين امر اض ميتواند از طريق مقاربت هاى جنسى نيز انتقال يابد و حتى باعث بيمار شدن كودكان در رحم زنان باردار نيز كردد.

Condyloma عمده ترين مرضى كه از طريق استفاده كلوخ انتقال ميابد، زخ ها است يك مرضى كد "Acuminatum ياد ميشود كه در اطر اف مقعد و الأ تناسلى ايجاد شده و شكل تاج خروس را به خود ميخيرد. حتى دليل به وجود آمدن برخى زخ هاى كه در رشت دست ها و پا ها نيز به وجود ميايد، استفاده از كلوخ و تماس با خاك است.

يكى از مشكلات عمده در اين قسمت اين است كه اكثريت مردم در كابل همجو موضوعات را رِيش "يا افتاده ميبينند و از صحبت و ارائه معلومات در اين مورد خود دارى كرده و حتى ميكًيد آنرا عار ميدانند. 
بيمارى هاى كه از طريق استفاده از كلوخ سرايت ميكند جدى اند و نبايد بزركان يا ملا امامان مساجد يا معلمين صحبت در مورد آنرا مايد شرمسارى بداند. ( استراتيزى صحت محيطى.بوب () امكان دارد • ا تا • ب فيعد مردم در كابل از همين طريق براى خشك كردن مجراى تناسلى خويش استفاده كنند و "اين فيصدى كمى نيست، امكان دارد كه سبب انتقال امر اض شود." اين موضوعى نيست كه از نعاه دينى به كسى بر بخورد، امامان نيز هر نظرى كه براى اصلاح جامعه بوده بيان كرد اند و داكتران، ملا امامان و معلمان نيز براى رفع مشكلات و بهبودى اجتماع نبايد از صحبت در اين مورد ننَّ يا عار كنند.

عدم موجوديت سيستمم كاناليز سيون در كابل باعث جلوكيرى از كثرت تشناب هاى عصرى شده است و مسؤولين حفظ محيط زيست ميكويند كه موجوديت همجو تشناب ها در نبود سيستم كاراى كاناليزسيون و حفر خاه هاى عميق مواد فاضله باعث آلودكى ذخاير آب زير زمينى ميكر دد. با وجود آنكه تا به حال در اين مورد احصايئ دقيقى در دست نيست اما داكتران ميكويند كه هنوز هم هزاران نفر به دليل استفاده از كلوخ در كابل به امراض مختلف مُصاب ميشوند. فروش غناماي كنار جاده در شهر كابل غذاهاى روى جاده يا همان فستفود افغانى، بزرگترين رقيبان رستورانهاى شهرند كه طرفداران خاص خود را از بخشهاى مختلف جامعه دارند و در هر گُشهى شهر يافت مىشوند. اين غذاها با انواع مختلف از جمله، جييس، بولانى، يكوره، برَّر، فلافل و شمار غذاىهاى زوديز ديخر كه در مدت جند دقيقه براى مشترىها آمده مىشوند. بيشتر اين غذاها در فضاى بهطور كامل غيرصحى و باز و در محلههاى ير رفتوآمد آماده مىشوند كه به لحاظ صحى بهاحتمالقوى مشكل سازند. تهيه كنندكًان و يا سرويسدهندكان اين غذاها، افراد بيشتر فقير و از طبقىى קايين جامعهاند كه براى فر اهمركردن مصارف خانوادهى شان، دست به اين كار مىزنند. 
بيشتر افراد كم درآمد مشتريان اصلى اين رستورانهاى سيار و يا فستفودهاى افغانىاند. افراد فقير، كاركران روزمزد، دانشآموزان و يا دانشجويان كه متعلق به خانوادههاى كم در آمدند، مشتريان دايمى اين نوع غذاهايند. شايد خيلى از اين مشتريان مى دانند كة اين نوع غذاها نإِكند؛ اما باز هم از آنها استفاده مى كنند. اين رستورانهاى سيار يا همان كراجى هاى لب جاده، مشتريان زيادى دارند. به ويزه آنهاى كه در مكان هاى ير رفتوآهد مانند

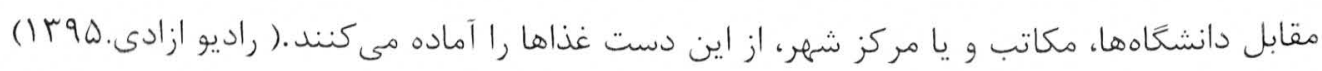
دو ويزَّى عمدهاى كه سبب شدهاند: اين نوع غذاها هميشه مشتريان خود را داشته باشند، ارزان بودن و در كنار آن آماده شدن در وقت كم است. هر خند براى مشتريان هميشكَى شايد به لحاظ طعم تازگى نداشته باشد . تنها افراد كم درآمد و يا طبقهى كم يول جامعه، مشتريان اين رستورانهاى سيار نيستند، كاهى افراد يولدار و يا كارمندان ادارات خارجى و داخلى نيز هوس استفاده از غذاهاى اين كراجىهاى لب جاده را دارند؛ اما حضور اين افراد خيلى جشمَّير نيست بيشتر مشتريان غذاهاى فستفود افغانى در كفتوكو با خبرنامه مى كويند: اين نوع غذاها به لحاظ پايين بودن و زود آمادهشن خوبند؛ ولى در قسمت صحى بودن اين نوع غذاها توجهى از طرف فروشندها صورت نمى گيرد، به ويزه در فصل زرما كه انواع ويروس ها به قدر كافى در فضا موجودند. در مواد غذايى غيرمصوون ·r . نوع ويروس وجود دارد كه شامل ويروسهاى سرطانى نيز هستند. غذاهاى لب

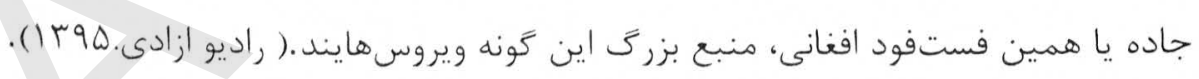
افرادى كه از اين غذاهاى استفاده مى كنند، بيشتر به امراض هضمى، سركيجى و استفراغهاى شديد روبهرو مىشوند" او تأكيد مى كند كه موادغذايى نيمزام حيوانى، سبزىهاى ناياى و رعايتنشن نكات صحى از سوى فروشندكان اين غذاها، سبب مىشود كه مشتريان اين رستورانهاى سيار، به امراض كَوناكون مبتلا شوند. فروشندكًان اين نوع غذاها درآ آد خوبى دارند. با وجودى كه به ظاهر كوحك و بدون امكانات به نظر مىرسند؛ اما به دليل داشتن مشترىهاى فراوان فروش خيلى خوب دارند .به ويزه در فصل هاى كه مكاتب و دانشامها شروع مىشوند و شاكردان كمتر از طرف روز در خانها غذا مى خورند. 
درآمد خوب اين شغل سبب شده است كه شمار زيادى از افراد بى كار با دست و يا كردن يك كراجى كوجى دست به پختن و فروش يكى از اين نوع غذاها بزنند. شايد يكى از دلايل عدم رعايت مسايل صحى، نآشنا بودن افراد با تختن غذا و عرضهى آن براى مشتريان باشد. بازار خوب فروشندى غذاها تعداد زيادى را به اين شغل كشانده است. شغلى كه به كفتهى خود فروشندكان در آمد خوبى دارند. يكى از اين فروشندكان كه خيلى از كارش راضى به نظر مىرسد، نويد است. او مى كويد با وجودى كه همه از بى كارى و نبود درآمد شكايت دارند؛ اما بازار كار او برعكس خيلى كرم است. نويد به خبرنامه مى كويد: امشترى هاى ما بيشتر افراد كم درآمد و دانشجوياناند. آنها به خاطر صرفهجويى در مخارج شان، به

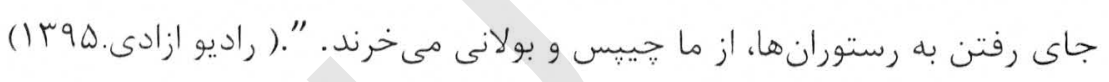

بيشتر صاحبان اين فستفودهاى افغانى، بدون جواز كار شان را ادامه مىدهند .زيرا شمار زياد آنها جييسيزى شغل اصلى شان نيست و به دليل بى كار ماندن دست به اين كار زدهاند. از سويى ديخًر يروسهى گرفتن جواز،

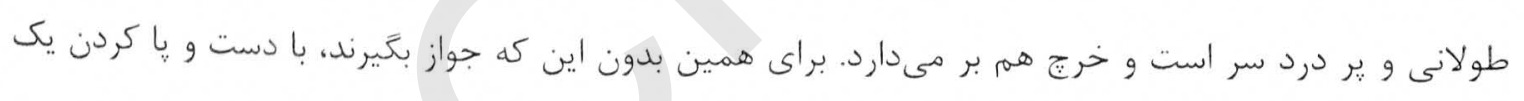
كراجى كوجى يا بزرى، شروع به اين كار كردهاند تا خانوادهى شان كرسنه نمانند. در كوشه و كنار جادههاى شهر كابل، مكانهاى زيادى ديده مى شود كه غذاهاى آماده و ارزان به مردم مىفروشند. بازار فروش غذاهاى آهاده، به دليل ارزان بودن، از رونق خوبى برخوردار است، اما سئوال اساسى اين است كه اين غذاها اكثر اين غذاها، يسمانده يا غذاهايى است كه از شفاخانه و يا برخى از نهادهاى دولتى به دست اين دستفروشان مى رسد. اكثر اين دست فروشان غذاها را با نرخ نازل به فروش مىرسانند به دليل اينكه در قبال تهيهى آن قيمت

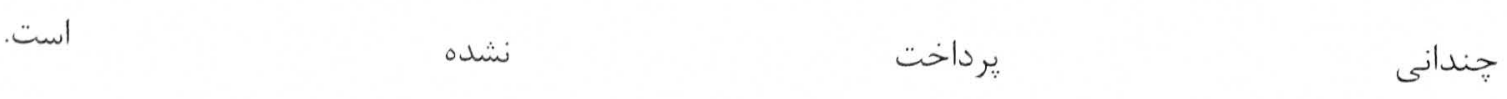

فروش غذاهاى ارزان در كنار سركها، بازار ير رونقى دارند. زيرا اين غذاها براى بخشى از مردم به صرفه است و

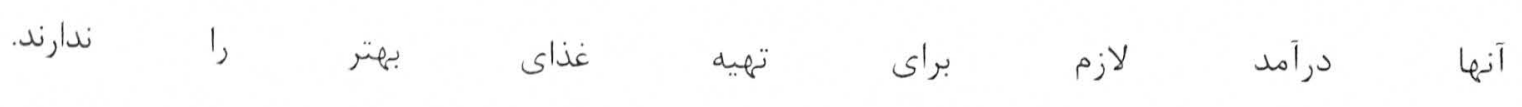


اما اين غذاها به مصونيت غذايى شهروندان كشور صدمه جبران نايذير بزند و سلامت و صحت آنها را در خطر قرار دهد. بخشى از غذاهاى كه در كنار سرك ها به فروش مىرسد، در خانه ها و در شرايط بهداشتى نامناسب تهيه مى شود. اين امر مىتواند منجر به افزايش بيمارىهاى گَوناگون شود، اما هنوز مورد توجه وزارت صحت عامه و ساير

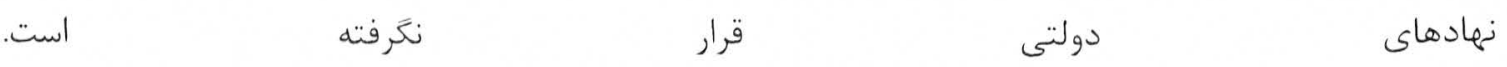
علاوه بر اين، اين غذاها با استفاده از آب جوىهاى كنار درياى كابل ٍخته مىشود. گَزارشهاى زيادى نشان مى دهد كه اين آبها با انواع ميكروبها آلوده است و استفاده از آن مىتواند منجر به بيمارىهاى گَوناكون شود.

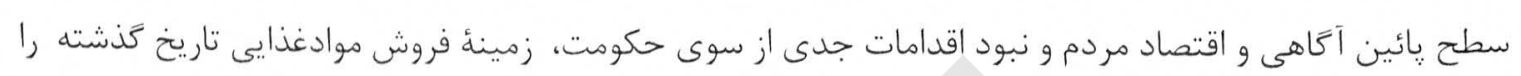

$$
\text { در بازارهاى كابل، مساعد كرده است..( راديو ازادى.هوبr ) }
$$

در قسمت هايى از شهر كابل جون مقابل مسجد يل خشتى، بعضى موادغذايى تاريخ كَّشته به صورت آزادانه به فروش ميرسد.

اين مواد به علت كذشتن تاريخ آن، ارزانتر فروخته ميشوند و كسانى كه داراى توان ضعيف اقتصادى هستند و يا سواد كافى ندارند، اين مواد را خريدارى ميكنند. افرادى كه اين مواد را روى كراجى ها جيده اند، در فروش آن با هيج مشكلى مواجه نيستند؛ آنها به هيج صورت حاضر نيستند تا منبع خريد اين مواد را افشا كنند.

اما شمارى از مردم با آنكه سواد دارند و مى توانند تاريخ انقضاى مواد را تشخيص دهند، به دليل ارزان بودن، از مواد تاريخ تيرشده استفاده مى نمايند و دليل آنرا مشكلات اقتصادى عنوان مى كنيد. اين درحالى است كه استفاده از موادغذايى تاريخ كذشته، براى صحت بسيار مضر است و سبب امر اض قلبى وغيره

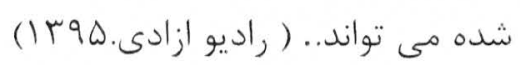


فروش غذاهاي غير صنى مر مقابل مكاتب تعدادى از شاكردان مكاتب شهر كابل در اثر استفاده از مواد خوراكى غير صحى كه در مقابل مكاتب شان به فروش

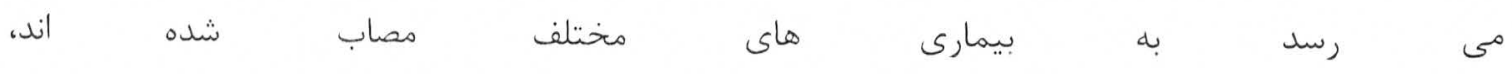
در دكان ها و كراجى ها كه در مقابل مكاتب وجود دارد، انواع مختلف مواد غذايى مثل بركر، بولانى، جِيس، منتو، تخم، شور نخود، مشنَّ، نوشابه هاى مختلف، آيسكريم، زاله، دوغ و امثال اين ها به فروش مى رسد. مشكلات اقتصادى آنان را مجبور ساخته تا در مقابل مكاتب مواد خوراكه را بفروش برساند... راديو ازادى.هوب1)

$$
\text { سلمانى هاى روى سرك دمر شهبر كابل }
$$
از كذشته هاى دور ديده شده است كه برخى افراد در كنار سرك ها نشسته با كر فتن يول اندك ريش و موى مردم را اصلاح مى كنند. اين سلمانى هاى سيار اكثراً در مناطق مثل پيل خشتى، سر خوك، جاده و برخى مناطق ديكًر شهر كابل موجود اند. سلمانى هاى كه در يِياده رو ها موى و ريش مردم را اصلاح ميكنند، هنوز در برخى از نقاط شهر كابل فعال اند. ده ها سلمان بدون يرداخت كرايه دوكان و يا داشتن وسايل مدرن امروزى از اين راه امرار حيات مى كنند.

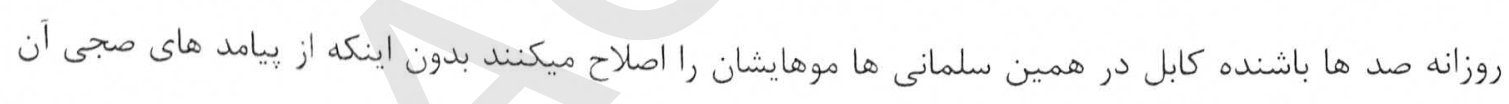
توجهى اشته باشند. يكى از راه هاى انتقال ويروس اج آى وى كه عامل بيمارى ايدز است، استفاده از تيغ هاى مشترك و آلوده است. بر علاوه ويروس اج آى وى ويروس هاى امر اض زردى سياه و ويروس بعضى امراض ديخًر نيز از طريق تيغ هاى آلوده سلمانى ها از يك شخص به شخص ديخر منتقل ميشود... (راديو ازادى.هوب |) 


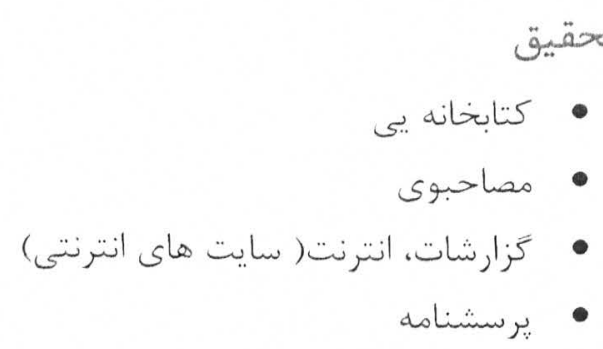

يافته ماى تمقيق ارقام ارايه شله توسط شفانخانه ما در باره اسمبالات در شهر كابل

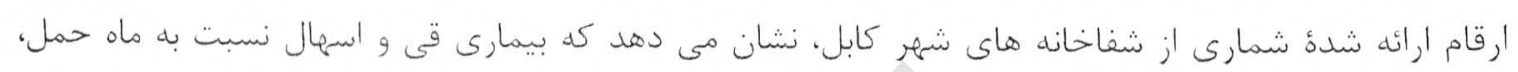
حدود جهار برابر افزايش يافته است. داكتران علت افزايش اين بيمارى راكرم شدن هوا عنوان مى كنند و مى كويند كه آلوده كى محيط زيست، مراعات نكر نن حفظ الصحه و عدم دسترسى شمارى از مردم به اب آشاميدنى صحى، عوامل اين بيمارى مى باشند.

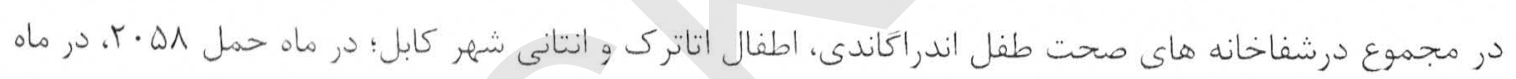

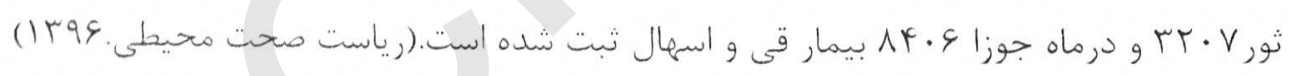

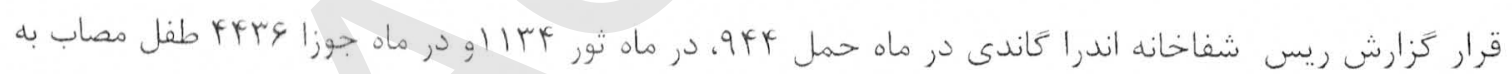
قى و اسهال، در اين شفاخانه ثبت شده كه عا تن آنها فوت كرنه و متباقى تداوى شده اند.

موصوف ارقامى در مورد بيماران قى و اسهال كه در ماه سرطان به آن شفاخانه مر اجعه نموده، ارايه نكرد؛ اما كَفت كه رقم همجو بيماران در اين شفاخانه در حال افزايش است. منبع خاطرنشان ذمود كة هر سال، با كرم شدن هوا، ابن بيمارى افزايش مى يابد.

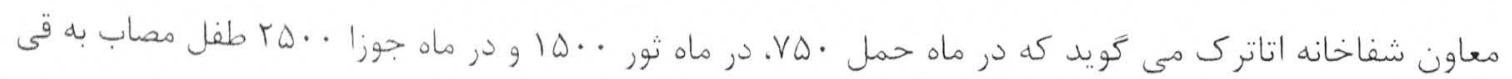
و اسهال، به اين شفاخانه انتقال يافته، كه ثا تن آنها فوت نموده و متباقى تداوى شده اند. 
آمار بيمارانى را كه در ماه روان به آن شفاخانه مر اجعه نموده ارائه نشده؛ اما با توجه به بيمارانى كه مراجعه مى كنند، اين بيمارى درحال افزايش است.

اكثر بيمارانى كه به اين شفاخانه ها مراجعه مى كنيد، باشنده كان كابل مى باشند؛ اما شمارى از بيماران ولايات همجوار نيز به اين شفاخانه ها مراجعه مى كنند. اين بيمارى، در بزرَّالان نيز افزايش يافته است

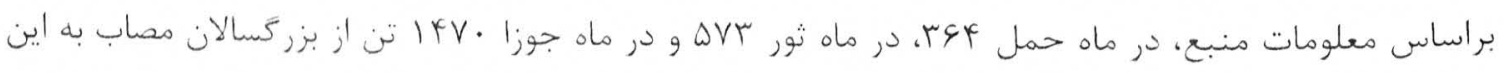
بيمارى، در شفاخانٔ يادشده تداوى شده اند.

كه اين بيمار، نزد بزر كسالان خطر ناك نيست وطى سه سال اخير، هيج واقعة فوتى از اثر اين بيمارى در شفاخانة يادشده ثبت نشده است.

شفاخانٔ انتانى كابل، يكانه شفاخانه براى تداوى همجو بيماران درسطح كشور مى باشد. اين در حالى است كه شمارى از بيماران قى و اسهال، به ساير شفاخانه هلا و ديكر مر اكز صحى در مركز و ولايات كشور مراجعه مى كنيد. (رياست صحت محيطى. צو (1)

طى سال كَشته . . ع r مر يض قى و اسمال به شفاخانه ها مراجعه نموده بودند. براين اساس سال كَذشته 91 طفل مصاب به اين بيمارى فوت كرده و متباقى بيماران، تداوى شده بودند) لهوبا ـ كزار شات شفاخانه هاى شهر كابل)

تعيه آب آشاميدنى صحى، از بين بردن كثافات و آب هاى مصرف شده، صحى ساختن أب به طرق مختلف، حفظ الصحذ فردى، فاميلى و اجتماعى، تهيه و نكَهداشت و خوردن غذاهاى صحى، طرق وقايه از امر اض سارى خون اسمالات و غير0، مى باشد. 
براى جلوكَيرى از اين بيمارى، بايد آب جاه هاى سرباز، جشمه ها و كاريزها قبل از نوشيدن جوشانده و يا با استفاده از محلول و يا تابليت كلورين، واك شود.

مادران، قبل از شيردادن به طفل، يُتان خود را با آب و صابون بشو يند و متوجه نظافت خود و اطفال خود باشند. همجنان براى جلوكيرى از اين بيمارى، بايد به طفل شير خوار، شير مصنوعى و توسطا جوشك داده نشود و درصورت ضرورت، بايد جوشك به درستى شستشو شده و از دادن شير باسى براى طفل، جلوكيرى كردد. براى شخص مصاب به اسهال، به خصوص اطفال مصاب، بايد مايعات و غذاى كافى داده شود و كارهاى نادرستى جون قطع كردن شيرمادر بر طفل مبتلا به اسهال و قطع كردن بعضى غذاها بر مادر طفل معاب، عملى نتر دد. والدين بايد به اطفال شان، تفهيهم نمايند كم از خوراكه هاي غيرصحى در بازار استفاده نكنند. قبل از خوردن غذا و بعد از أن و همجنان بس از رفع حاجت، بايد دست ها با آب وصابون شستشو شود. افراد مبتلا به اسهال و استفراغ، كه دفعات آن در F باعاعت بيشتر از + بار باشل، بايد غرض تداوى به مركز صحى

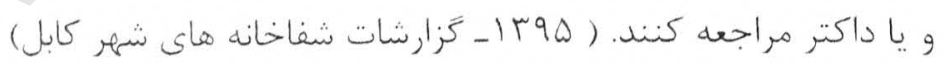

تر كارى و ميوه هاى تازه را با آب شسته و براى حد اقل ينج دقيقه در محلول نمك و يا كلورين بكَارند تا مكروب هاى آن از بين برود. براى جلوكَرى از مصاب شدن به اسمبال و استفراغ، بايد ازخوردن غذا هاى شب مانده، خود دارى شود. واكسين سُّ ديوانه واكسين مرض سگ ديوانه رياست حفظ الصحه منازل و شهر ها، در سطح شهر كابل سالانه حد اقل بيش از .... - . . . . . واقعه تأييد شده مرض سگَ ديوانه كه وقايه شده و يا واكسين ميشوند، به مشاهده ميرسد. واضحاً تعداد

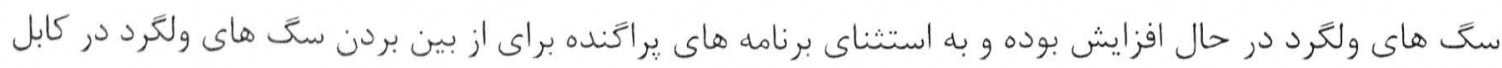




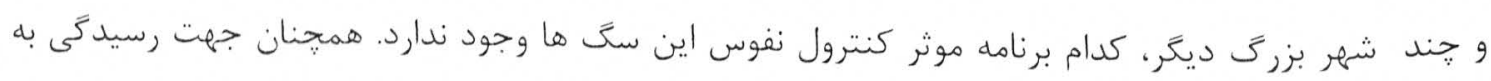
واقعات كز يدن سگَ هاى وحشى، شاروالى ها به كمك وزارت صحت عامه سگ هائى را كه در مناطق شهرى وجود دارند، از بين ميبرند. احصائيه/راجستريشن سعَ هاى ولكَرد وجود نداشته و نيز روش هاى كاهش تعداد اين سُ ها يا فراهم آورى واكسين ها موجود نيست. براساس راجستريشن صحت محيطى، بخاطر كمبود واكسين مرض سگ ديوانه، واقعاتيكه گزيدَى سخ هاى خانكًى يا وحشى بدون واقعات كلينيكى بيش از . . .9 واقعه ميباشند. (رياست صحت محيطى. ع بم ()

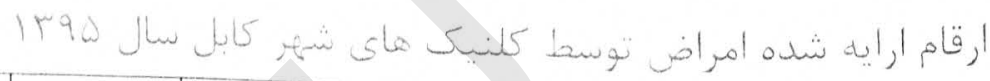

\begin{tabular}{|c|c|c|c|c|c|c|c|c|c|c|}
\hline نشفاخ ناند & $\begin{array}{r}\text { Acute } \\
\text { blood } \\
y \\
\text { diarrh } \\
\text { ea }\end{array}$ & $\begin{array}{r}\text { Acute } \\
\text { water } \\
\text { diarrh } \\
\text { ea }\end{array}$ & $\begin{array}{l}\text { Cou } \\
\text { gh } \\
\text { and } \\
\text { cold }\end{array}$ & $\begin{array}{r}\text { Diarrhea } \\
\text { with } \\
\text { dehydriti } \\
\text { on }\end{array}$ & $\begin{array}{r}\text { Gastro } \\
\text { intesti } \\
\text { nal } \\
\text { worms }\end{array}$ & $\begin{array}{r}\text { Skin } \\
\text { infecti } \\
\text { on }\end{array}$ & $\begin{array}{r}\text { Skin } \\
- \\
\text { othr }\end{array}$ & $\begin{array}{r}\text { Tb } \\
\text { suspect } \\
\text { ed }\end{array}$ & $\begin{array}{r}\text { malar } \\
\text { ia }\end{array}$ & $\begin{array}{r}\text { Tetan } \\
\text { us }\end{array}$ \\
\hline افتشار & V4 & ra. & $r \cdot r$ & $\Delta 9$ & TrT & TY & r. & $+\wedge$ & & \\
\hline 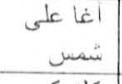 & FFY & $r .+\Lambda$ & rul & & & 1119 & & 9. & & \\
\hline كلنيك & IOV & $90 r$ & $\frac{1 r 1}{r}$ & r. & rir & 191 & 01 & 1. & & \\
\hline 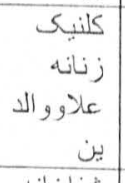 & to & $\Delta r$ & Mr & to & 19 & to & rq & & & \\
\hline |نتفانَانه & TGVY & IFrA & $r \lambda 1$ & VATI & $1+4$ & 9 & 0 & +9 & rVA & 11 \\
\hline أناترى & 145 & 10194 & $\begin{array}{l}\text { Irr } \\
V F\end{array}$ & $1 / 90$ & $9 \times 9$ & 15 & 1 & $1 r 1$ & $\Delta$ & $r$ \\
\hline كلنيك ادئ & YAY & Ir.d & $\Delta F$. & 99 & TAI & 19. & 9. & do & 1. & \\
\hline |كلنيك & 109 & AV 9 & $\begin{array}{r}140 \\
1\end{array}$ & $d$ & DIV & $0 \times 9$ & 99 & $1+r$ & F & \\
\hline كرئنيى & 1.81 & rFqY & $\begin{array}{r}9.6 \\
4\end{array}$ & 44 & $1+r+9$ & $11 r v$ & $\begin{array}{l}\text { YVo } \\
\text { Y1 }\end{array}$ & 1999 & $r .9$ & \\
\hline كلنيك & 11.9 & IFFA & $\begin{array}{r}194 \\
r\end{array}$ & r & IFrA & $10+\lambda$ & 1 & VY & & \\
\hline
\end{tabular}




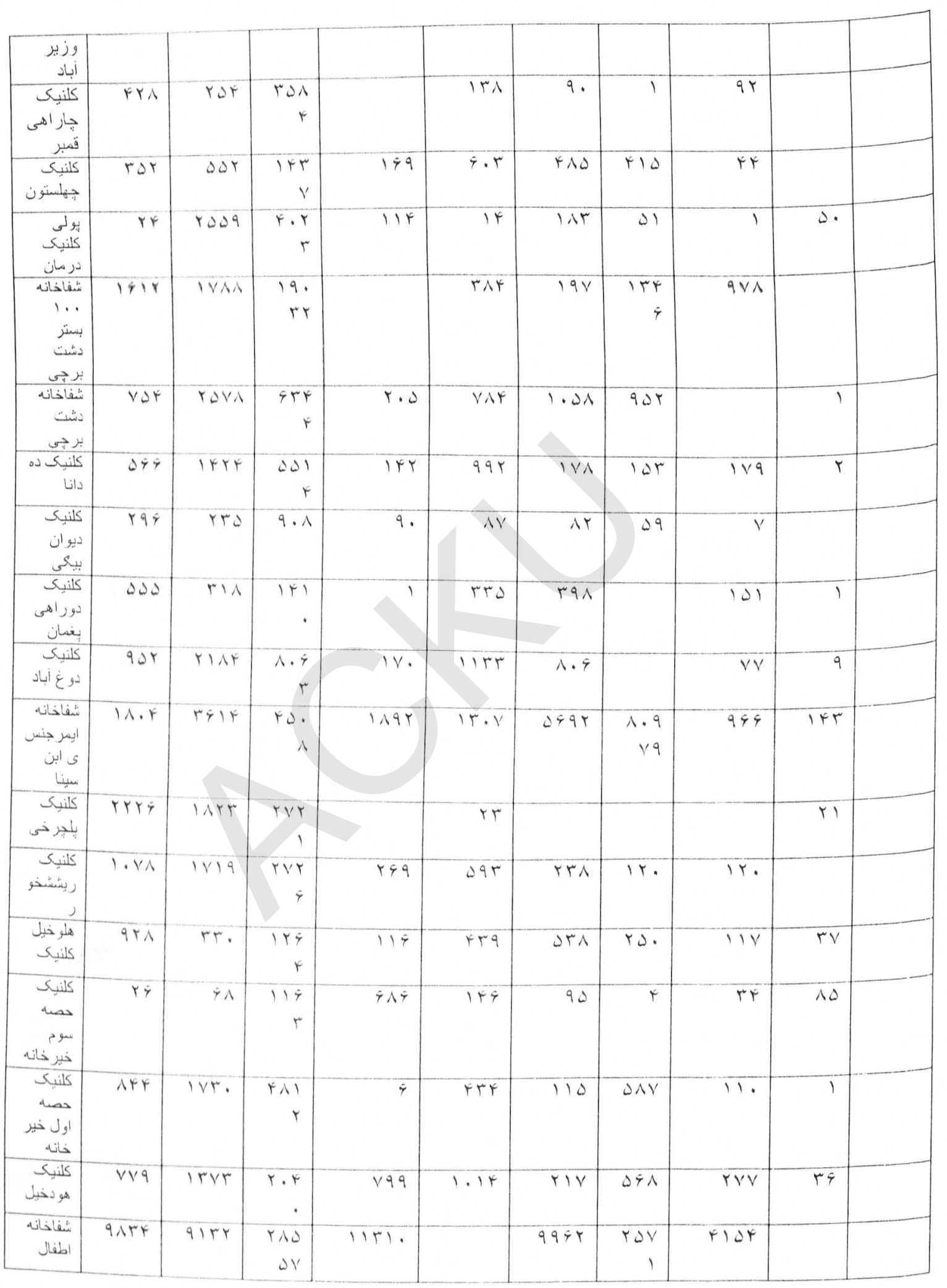




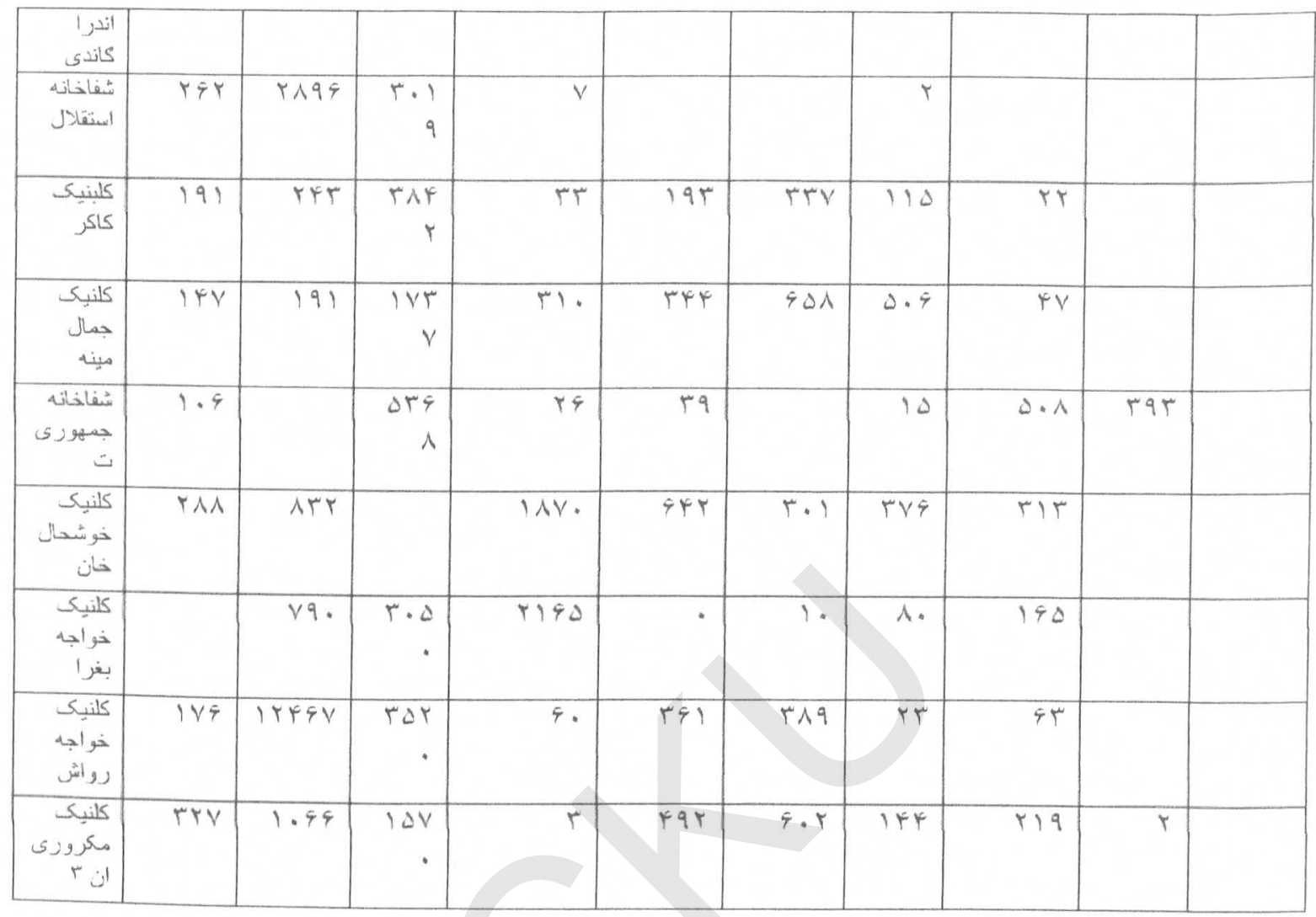

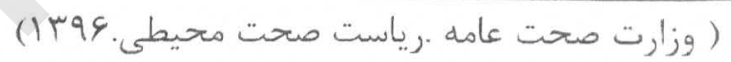

ارقام ارايه شده توسط شفاخانه هاى افشار، أغا على شمس

$$
\text { وعلاوالدين }
$$

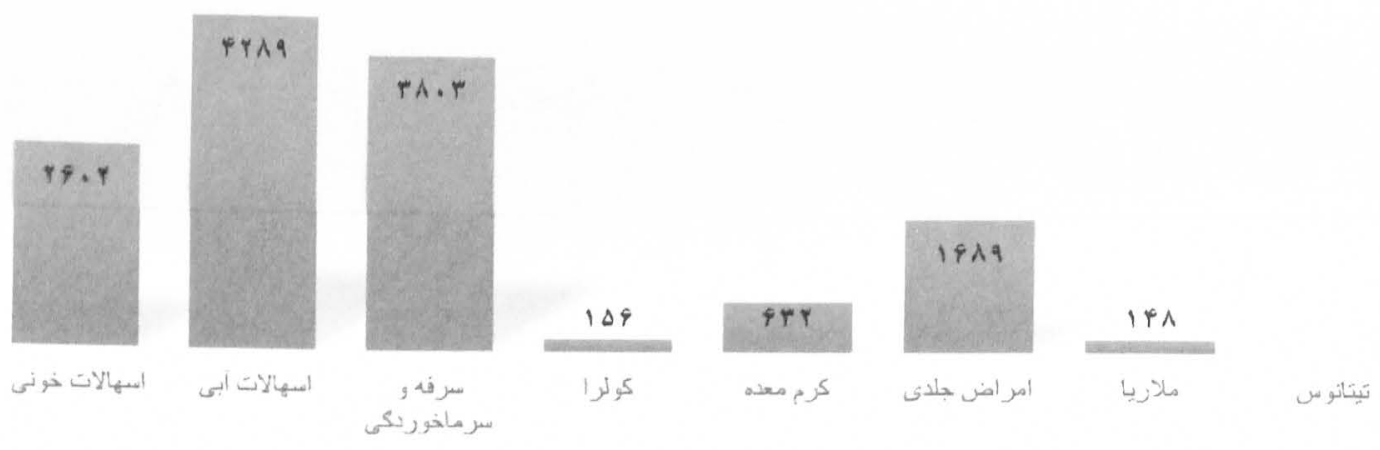


نظر به ارقام ارايه شده توسط شفاخانه هاى ذيل معلوم ميشود كه بيشترين امراض بوجود آمله از آب، هوا و غذا ميباشد.

\section{Chart Title}

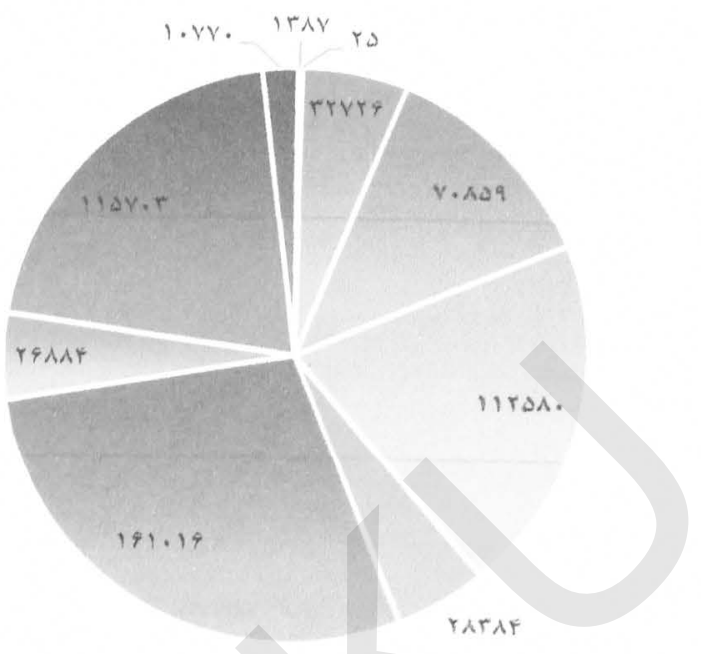

$$
\begin{aligned}
& \text { اسبهالات خونى " }
\end{aligned}
$$

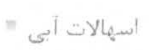

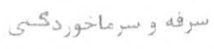

$$
\begin{aligned}
& \text { كولر } 1= \\
& \text { كرم روده " } \\
& \text { أمر ض جلدى " } \\
& \text { دى كى, أمراض جلدى " امراض جلدي } \\
& \text { توبر كلوز " } \\
& \text { ملاريا " مان } \\
& \text { تيتانوس " }
\end{aligned}
$$

وزارت صحت عامه (هوبr ()ارقام امراض كه به كلنيك ها و شفاخانه هاى شهر كابل مراجعه شده 


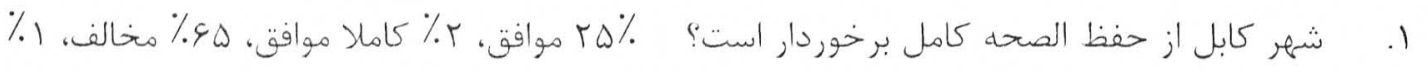
كاملا مخالف، V \% عادى

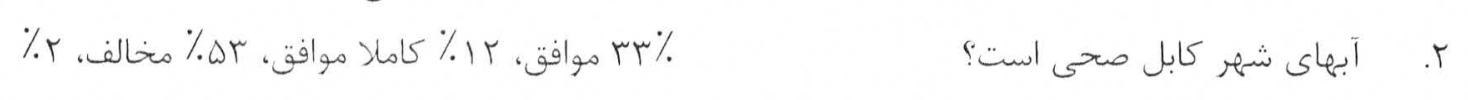

كاملا مخالف

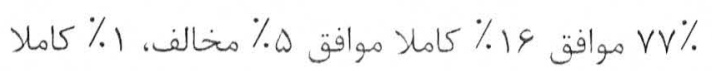

r. مر مدم در شهر كابل از تشناب ها استفاده

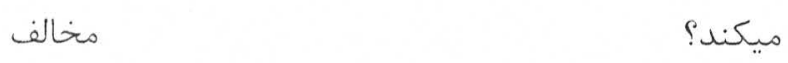

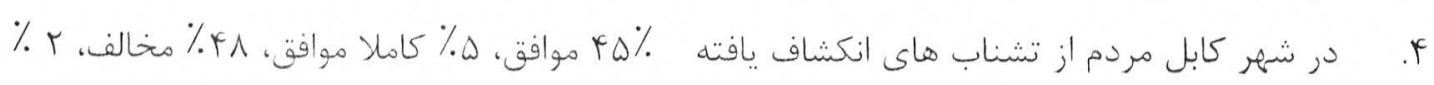

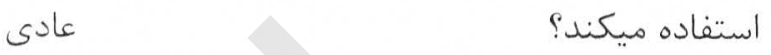

$$
\begin{aligned}
& \text { ه. مردم در شهر كابل از تشناب ها استفاده تكرار } \\
& \text { ميكند؟ }
\end{aligned}
$$

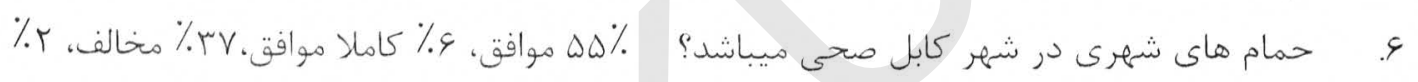
كاملا مخالف

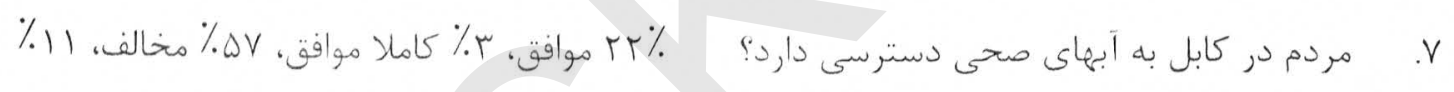
كاملا مخالف، r \%

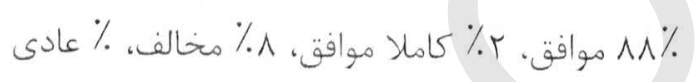

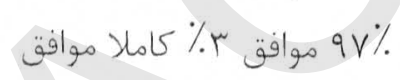

$$
\begin{aligned}
& \text { ^. آيا به غذاى صحى دسترسى داريد؟ } \\
& 9 \text { 9. }
\end{aligned}
$$$$
\text { آمدن امراض رول داردي }
$$

• 1.

$$
\text { بوجود آمدن امراض رول دايت دا؟ }
$$

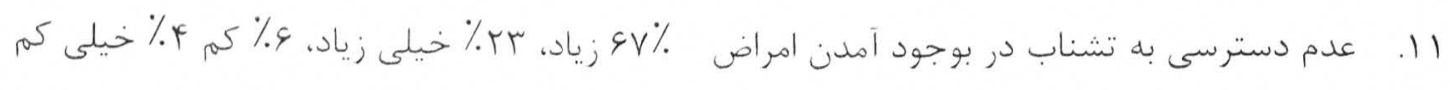

$$
\text { رول دارد؟ }
$$

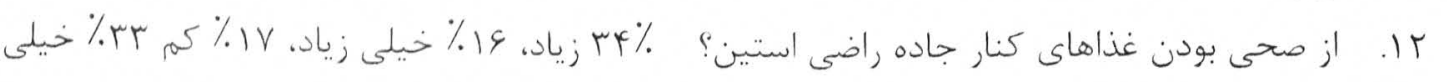

$$
\begin{aligned}
& \text { ros }
\end{aligned}
$$

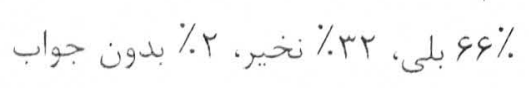

$$
\begin{aligned}
& \text { rا. آيا در باره حفظ الصحه معلمات داريد؟ }
\end{aligned}
$$

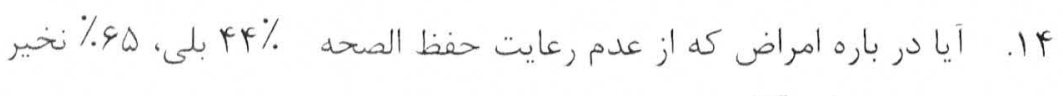

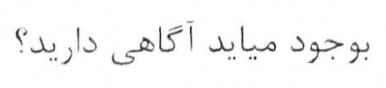




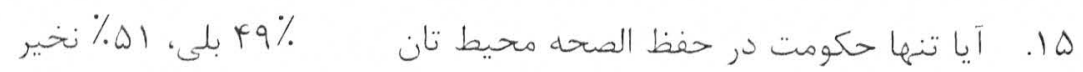
رول دارد

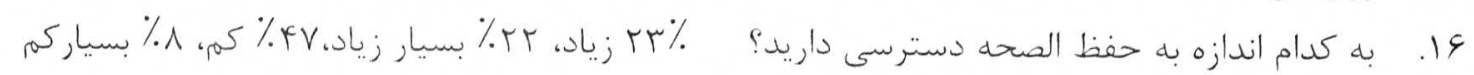

$$
\begin{aligned}
& \text { IV I آ. آيا به وسايل ضد عفونى دسترسى داريد؟ }
\end{aligned}
$$

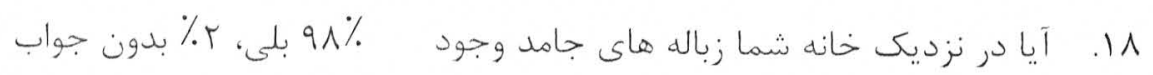

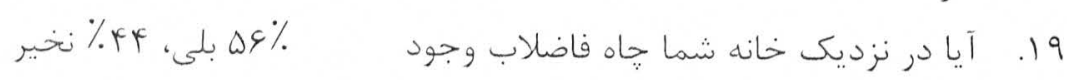

$$
\begin{aligned}
& \text { (s) }
\end{aligned}
$$

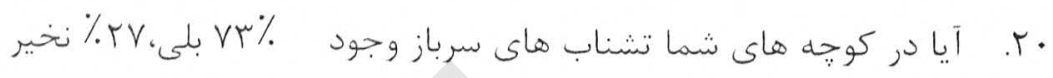

$$
\begin{aligned}
& \text { is }
\end{aligned}
$$

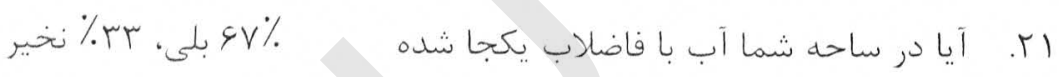

$$
\begin{aligned}
& \text { است؟ }
\end{aligned}
$$

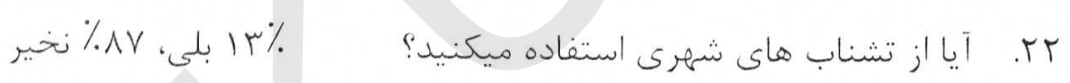

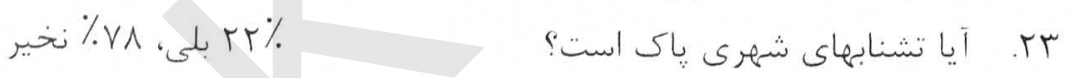

$$
\begin{aligned}
& \text { F } \\
& \text { شده }
\end{aligned}
$$

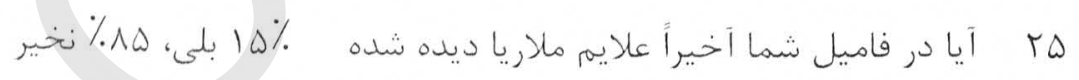

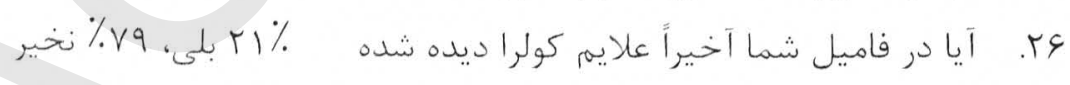

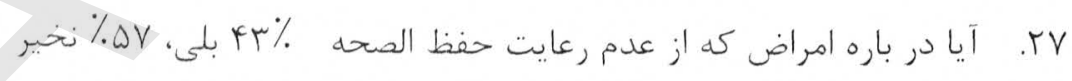

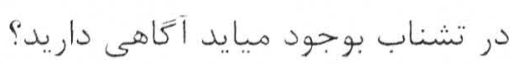

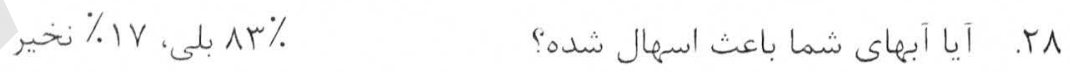

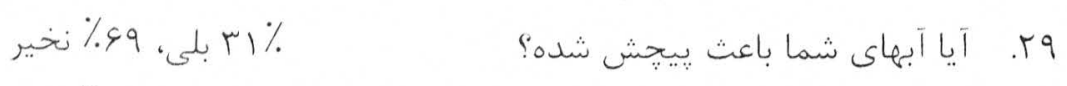

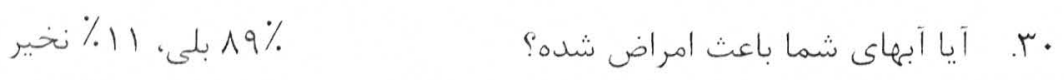

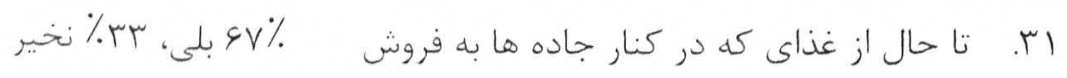

$$
\begin{aligned}
& \text { ميرسد مسموم شده ايد؟ } \\
& \text { rr }
\end{aligned}
$$

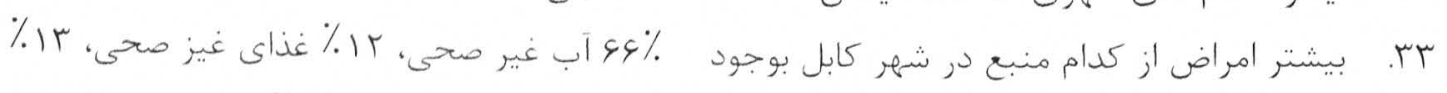

$$
\begin{aligned}
& \text { ميايد؟ }
\end{aligned}
$$




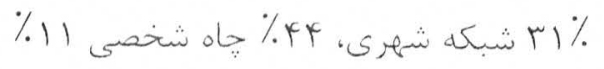

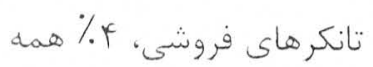

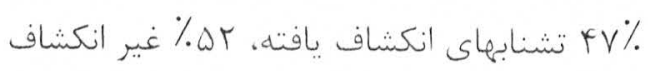

$$
\begin{aligned}
& \text { يافته، } 1 \text { \% \%مه } \\
& \text { r r . منبع اصلى آب نوشيدنى شما جه است؟ } \\
& \text { فّا. از جه نوع تشنابها استفاده ميكنيد؟ }
\end{aligned}
$$

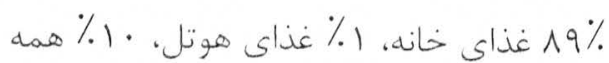

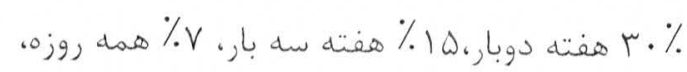

$$
\begin{aligned}
& \text { צr. از جى نوع غدا استفاده ميكنيد؟ } \\
& \text { rV }
\end{aligned}
$$

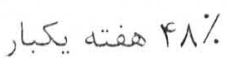

$$
\begin{aligned}
& \text { تكرار }
\end{aligned}
$$

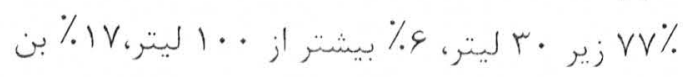

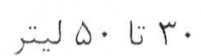

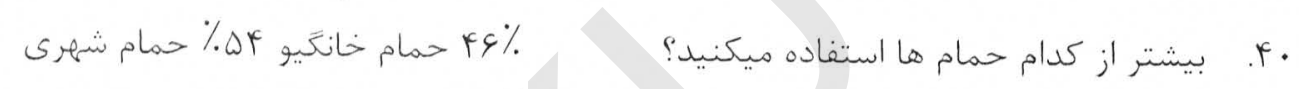

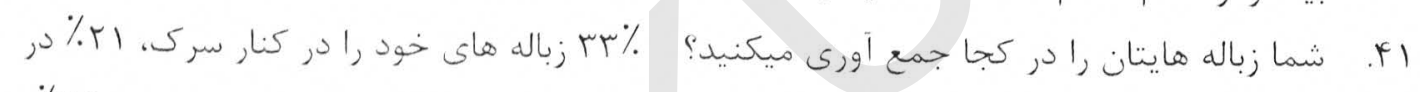

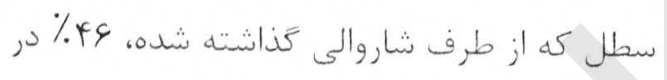

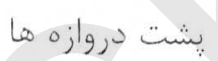

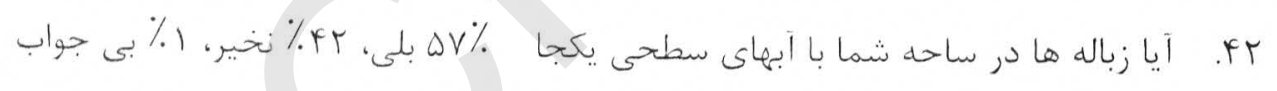

$$
\begin{aligned}
& \text { شده }
\end{aligned}
$$

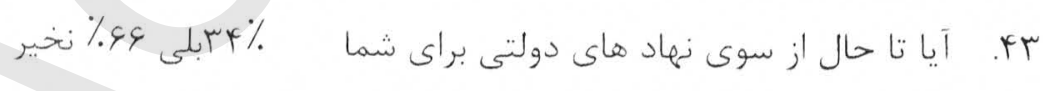

$$
\begin{aligned}
& \text { در باره حفظ الصحه آكاهى دهى شده }
\end{aligned}
$$




\section{آيا شهر كابل از حفظ الصحه كامل برخوردار است}

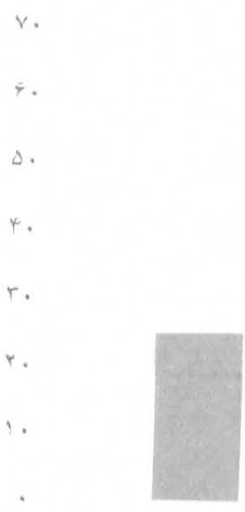

موافن

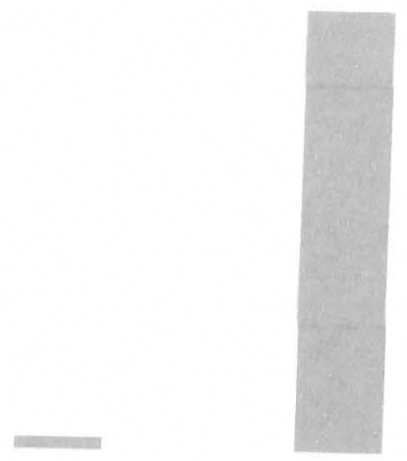

موان

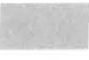

sole

بحر اساس اين كراف كَفته ميتوانيم كه مردم در شهر كابل به حفظ الصحه دسترسى نداشته جوابات حاصل از

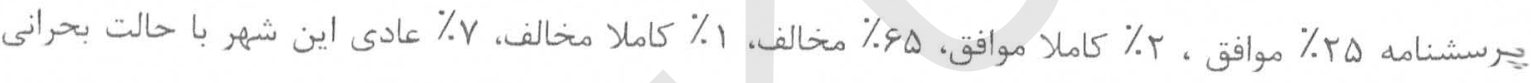
است

حفظ آبهاى آشاميدنى شهر كابل صحى است

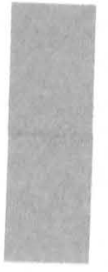

موافن

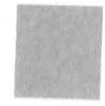

is

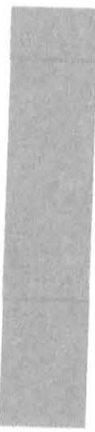

ميخالف

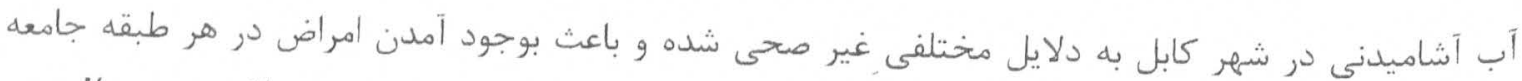

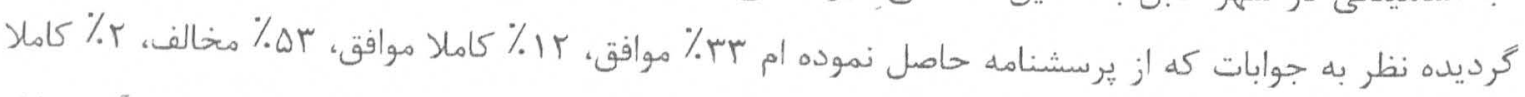
مخالف بوده و در نتيجه ميتوانيم كففت كه آب شهر كابل نايالم بوده و بسيار كم مناطق بيدا ميشود كه آبش قابل نوشيدن و صحى باشد 


\section{مردم در شهر كابل از تشنابهاى انكشاف يافته استفاده ميكند}

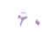

¿.

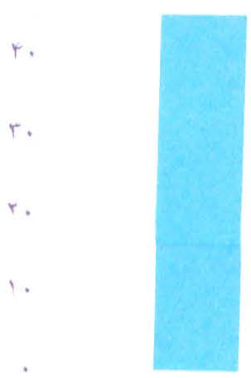

موائق
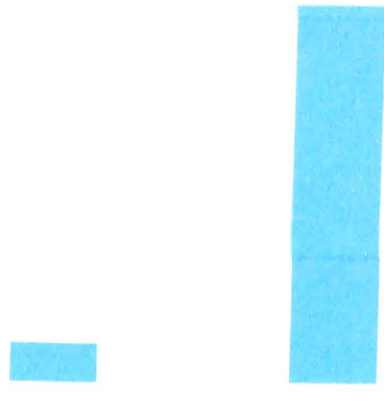

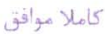

مخالف

در اينجا بر اساس جوابات بدست آمده كفته ميتوانيهم كه در شهر كابل بيشتر مردم به تشناب هاى ساده دسترسى

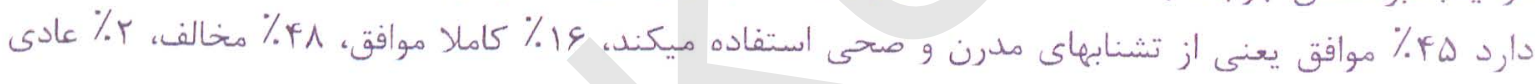

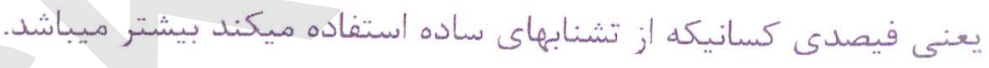

مر دم در شهر كابل به آبهاى صحى دسترسى دارد

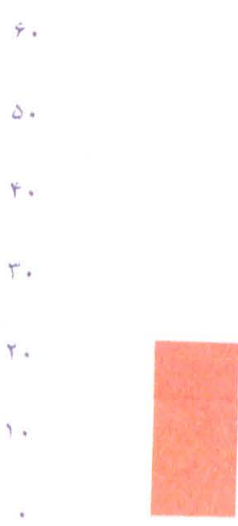

مو ف

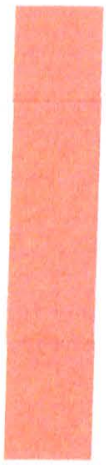

منالف

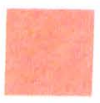

كاملا ميحاف

نظر به جوابات كه از بر سشنامه حاصل نموده ام درميابم كه بيشتر مردم در شهر كابل به آب صحى دسترسى ندارد

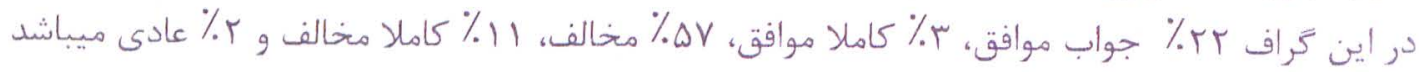




$$
\text { pot }
$$




\section{نتيجه كيرى}

شهر كابل از جمله آلوده ترين مراكز دنيا ميباشد كه با داشتن بيشتر از شش ميليون نفوس داراى حفظ الصحه سالم نيست عدم موجوديت آب أشاميدنى، غذاى غير صحى، عدم موجوديت سيستم كاناليزاسيون، عدم موجوديت تشناب هاى صحى، عدم اكَاهى، اقتصاد بايين مردم، موجوديت فاضلاب بعضى از خانواده ها در فضاى آزاد از جمله مشكلات است كه باعث شيوع امراض جون اسهال، كولرا، استفراغ اطفال، محرقه و ملاريا شده است. آب هاى شهر كابل در مجموع صحى كَفته نميشود ساحات كه آب آشاميدنى صحى داشته باشد بسيار كمياب ميباشد در كل •V٪ آبهاى زير زمينى در شهر كابل آلوده شده و غير صحى ميباشد جون بيشتر مردم شهر كابل

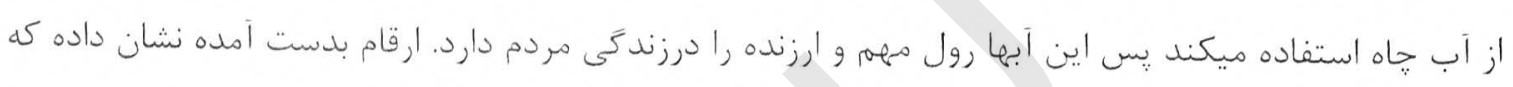
معمول ترين امراض بوجود آمده از اين آبها اسهال، استفراغ اطفال، كولر و ملاريا ميباشد.

آبهاى زير زمينى به علت عدم مديريت، نبود سيستم كاناليزاسيون، نزديك بونن خاهاى فاضلاب آلوده شده و غير صحى ميباشد در حال حاضر r r امراض كه در شهر كابل به مردم بيش آمده از ناياك بودن و آلوده بودن آب بوده است. غذاى كه مردم در شهر كابل استفاده ميكند كمتر باعث امر اض و مسموميت ها كرديده هست مكَر غذاهلى كه در كنار جاده هما به فروش ميرسد غير صحى بوده و بعضى از اين فروشنده ها غذاهلى باسى مانده را به فروش مير ساند كه باعث مسموميت هاى غذايى گَرديده و حتا باعث مرك اطفال ميكر دد. در كل در شهر كابل همه يى مردم از تشناب ها استفاده ميكنند ولى اين تشناب ها معيارى و داراى مواد و وسايل بهداشت نيست يك فيصدى كم مردم در شهر كابل از تشناب هاى انكشاف يافته استفاده ميكنند و متبافى از تشنابهاى غير انشاف يافته استفاده ميكند يك فيصلى كم وجود دارد كه تا هنوز همم از تشناب ها استفاده نميكند. در شهر كابل •f تشناب شهرى از سوى شاروالى كابل احداث شده اين تشناب ها صحى نيست و مردم از آن بيشتر اسفاده نميكند در شهر كابل بيشتر مردم از تشنابهاى كنار جاده استفاده ميكند استفاده از تشنابهاى كنار 
جاده ها به مردم فرهنَ شده اين عمل باعث آلوده شدن و ايجاد امراض در مردم كرديده امر اض كه از طريق عدم حفظ الصحه در تشناب ها ايجاد شده ملاريا،اسهال، ايدز، enteric fever, ambiasis, hepatitis B virus, hepatitis C virus, حمام ها شهر كابل صحى نيست مكَر حمام هاى هاى كه بشكل جدا است نسبت به حمام هاى دسته جمعى كه. بشكل صالون ميباشد صحى تر ميباشد مردم هفته r-r روز به اين حمام ها مر اجعه ميكند ولى بعضى از مردم به دليل نبود اقتصاد بالا نميتواند به اين سهولت ها دسترسى داشته باشل بيشتر مردم روزانه به كمتر از • ب ليتر آب دسترسى دارد حتا به كمتر از • ا ليتر نيز وجود دارد بيشتر مردم به دليل نبود امكانات از حمام هاى خانكى لئى استفاده ميكند. مردم زباله هاى خود را در كنار جاده ها سرك ها بشكل انبار مياندارد كه اين عمل باعث ايجاد اهراض و بوى بد ميشود زباله دانى هايكه از طرف شاروالى به كوجهه ها كذاشته شده همم كوجك ميباشد و همم تعداد آنما كم ميباشد در حاليكه حجم زباله ها زياد است. 


\section{vيشنهادات}

شبكه هاى آبر سانى استرهلاك شده و نيمه كاره بايد بازسازى و لدوباره فعال كَردد

كاسه ها و ذخاير آب بايد از تعرض مصيُون شوند و مردم در حفظ أن بكوشند.

ياكسازى كثافات از شهر كه در آلوده شدن آب نقش اساسى دارد ظرفيت شهردارى كابل در قسمت مبارزه

$$
\text { با كثافات شهرى بلند برده شده و اداره و امكانات آن زياد كردد }
$$

كَمينى هاى توليد آب صحى معلنى تخصص و اجازه نامه و لابر اتوار هاى منظم را داشته باشد شهردارى ها بايد كاملا خاه هاى سيتيك را تحت كنترول داشته باشد

جاه ها كود نمبر داشته باشد.

فعال شدن سيستهم منظهم انتقال زباله هاى شهرى و خود دارى از حفر خاه هاى جاذبه ميتواند تا حى

$$
\text { زيادى ا آلوده شدن آبها در شهر جلوكبرى كند }
$$

همكارى مردم در عرصه حفظ محيط زيست و پاك كارى سهم بيكيرند.

بالا بردن سطح آكاهى مردم در تقويت فرهنَّ توجه به محيط زيست

با ايجاد سيستم آبرسانى كاناليزاسيون از افزايش امراض جلوكيرى كني

$$
\text { • حفر خاهاى عميق و استفاده از كلورين. }
$$

مردم در حفظ كوجهه ها و دريا ها از زباله ها با شاروالى كمك كند.

$$
\text { باكسازى نرياى كابل }
$$

تعداد بيشتر سطل هاى زباله بايد به كَونه عادلانه در سطح كوحه هاى شهر كابل جابجا شود.

ساحات دفن زباله ها به كَونه علمى و اساسى مطابق نورم ها و استندرد ها بين المللى بنا شود 
تهيه آب آشاميدنى صحى، از بين بردن كثافات و آب هاى مصرف شده، صحى ساختن آب به طرق مختلف، حفظ الصحأ فردى، فاميلى و اجتماعى، تهيد و نكَهداشت و خوردن غذاهاى صحى، طرق وقايه از امراض سارى جون اسمالات و غيره، مى باشد. براى جلوكَيرى از اين بيمارى، بايد آب خاه هاى سرباز، جشمه ها و كاريزها قبل از نوشيدن جوشانده و يا با استفاده از محلول و يا تابليت كلورين، رياك شود. مادران، قبل از شير دادن به طفل، يستان خود را با آب و صابون بشويند و متوجه نظافت خود و اطفال خود باشند. همجنان براى جلوَيرى از اين بيمارى، بايد به طفل شير خوار، شير معنوعى و توسط جوشك داده نشود و درصورت ضرورت، بايد جوشك به درستى شستشو شه و از دادن شير باسى براى طفل، جلوكيرى Sر

براى شخص مصاب به اسمال، به خصوص اطفال مصاب، بايد مايعات و غذاى كافى داده شود و كارهاى نادرستى جون قطع كردن شيرمادر بر طفل مبتلا به اسمال و قطع كرن بعضى غذاها بر مادر طفل مصاب، عملى نَّر دد .

والدين بايد به اطفال شان، تفهيهم نمايند كه از خوراكه هاى غيرصحى در بازار استفاده نكنند. قبل از خوردن غذا و بعد از آن و همجنان هس از رفع حاجت، بايد دست ها با آب وصابون شستشو شود. افراد مبتلا به اسمبال و استفراغ، كه دفعات آن مر ب اساعت بيشتر از \& بار باشد، بايد غرض تداوى به مركز صحى و يا داكتر مراجعه كنند. تر كارى و ميوه هاى تازه را با آب شسته و براى حد اقل ينج دقيقه در محلول نمك و يا كلورين بحَارند تا مكروب هاى آن از بين برود. براى جلوكَيرى از مصاب شدن به اسهال و استفراغ، بايد ازخورن غذا هاى شب مانده، خود دارى شود 


$$
\begin{aligned}
& \text { منابع و ماخذ }
\end{aligned}
$$

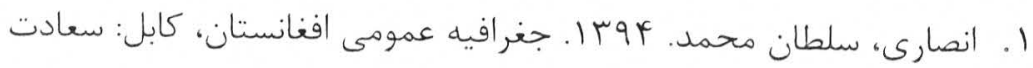

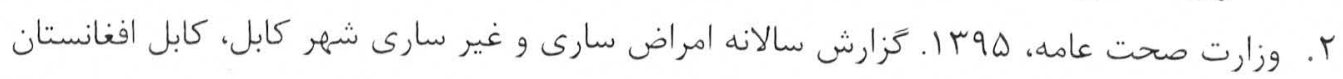

Central statistic organization (2015) Kabul province socio_demographic and r r economic survey highlight and result.

Central statistic organization (2014) national risk and vulnerability . $f$ assessment 2011-2 - 1r: Afghanistan living condation survey. Kabul.CSO Central statistic organization and European union (2009) national risk and . . velnerability assessment 2007/2008 a profile of Afghanistan. Kabul, Afghanistan: jehoon printing press.

United nation (1983), manualX: indirect techniques for demographic .9 United nation estimation. New York, united nations.

http://demographicestimation.tussp.org United nation department of economic and social affairs statistic . $\wedge$ division(2007), principles and recommendations for population and housing censuses. New York, united nations.
Ali akbari 1396, Kabul underground water.8/9/1396 [www.bbc.com] .9
rustami 1391, Kabul environment and water. 30/11/1391 [http://da .. . azadiradio.com] 
ضمايم

يرسشنامه

ا شهر كابل از حفظ الصحه كامل برخوردار است

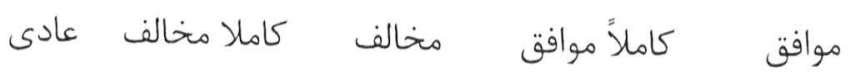

$$
\text { r آبهاى شهر كابل صحى ميباشد؟ }
$$

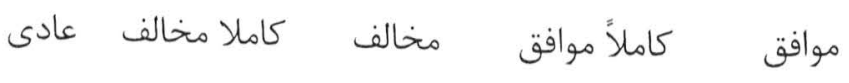

$$
\text { r مردم در شهر كابل از تشناب استفاده ميكني؟؟ }
$$

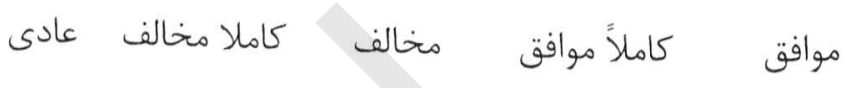
† مردم در شهر كابل از تشناب هاى انكشاف يافته استفاده ميكنند؟

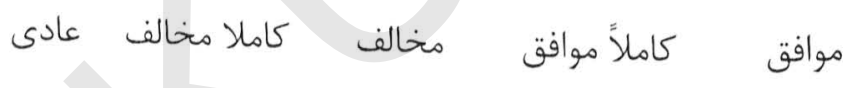
ه حمام هاى شهر كابل صحى ميباشد؟

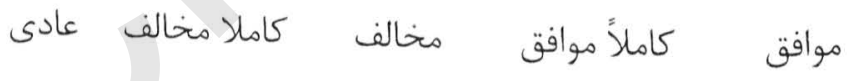

$$
\text { 9 مردم در كابل به آبهاى صحى دسترسى دراند؟ }
$$

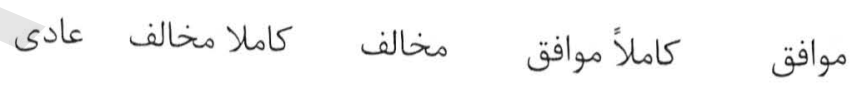

$$
\text { V مردم به غذاى صحى دسترسى دارند؟ }
$$

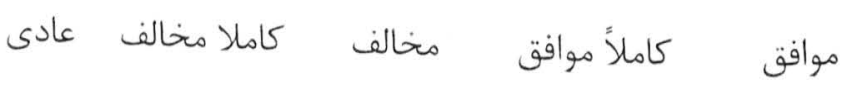

$$
\text { ^ آيا غير صحى بودن آب هاى هاه در بوجود آمدن امراض رول دارد؟ }
$$

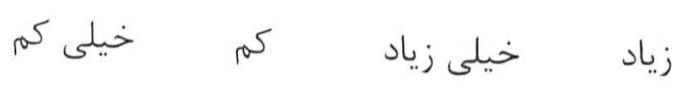

9 عدم رعايت حفظ الصحه بعد از رفع حاجت در بوجود آمدن امراض رول دارد؟ زئ

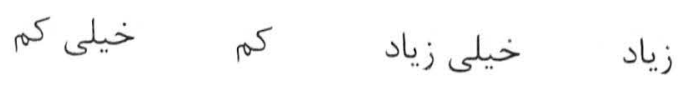

. اعدم دسترسى به تشناب ها در بوجود آمدن امراض رول دارد؟ رِي 


$$
\text { زياد }
$$

سا آيا در باره امراض كه از عدم حفظ الصحه بوجود ميآيد اكاهى داريد؟

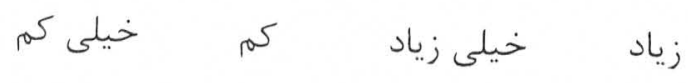

ץ ا آيا تنها حكومت در حفظ الصحه محيط تان رول دارن؟

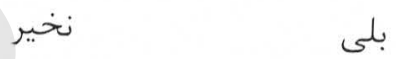

ها به كدام اندازه به حفظ الصحه دسترسى دارند؟

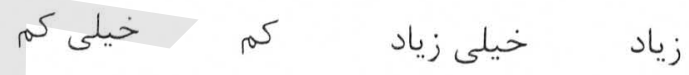

عا آيا به وسايل ضد عفونى دسترسى داريد؟

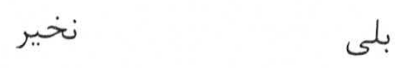

V V آ آيادر نزديك خانه شما زباله هاى جامد وجود دارد؟

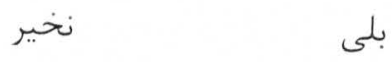

1 آيا در نزديك خانه شما جاه فاضلاب وجود دارد؟

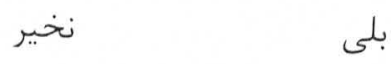

9 آ آيا در كوجه هاى شما تشناب هاى سرباز وجود دارد؟

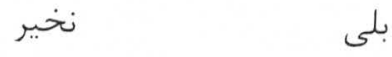

r r آيا در ساحه شما آب با فاضلاب يكجا ميشود؟

بلى 


$$
\begin{aligned}
& \text { ا T آيا از تشناب هاى شهرى استفاده ميكنيد؟ } \\
& \text { نخير } \\
& \text { بلى } \\
& \text { r Trآيا تشنابهاى شهرى پاى است؟ }
\end{aligned}
$$

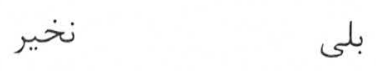

r ب آيا در فاميل شما آخيراً علايم, اسمال ديده شده

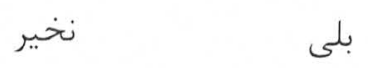

F T T آيا در فاميل شما آخيراً علايم ملاريا ديده شده؟

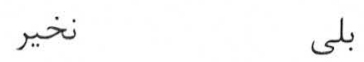

L T آآيا در فاميل شما آخيراً علايم كولرا ديده شده؟

$$
\text { بلى }
$$

צب آيا در باره امراض كه از عدم رعايت حفظ الصحه در تشناب بوجود ميايد آكاهى داريد؟

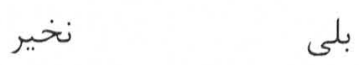

$$
\begin{aligned}
& \text { V Tr آيا آب شما باعث اسهال شده؟ } \\
& \text { نخير }
\end{aligned}
$$

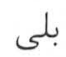

$$
\begin{aligned}
& \text { ^r آيا آب شما باعث يِحش شده؟ } \\
& \text { نخير }
\end{aligned}
$$

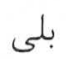

$$
\begin{aligned}
& \text { وץ آيا آب شما باعث امراض شه؟ } \\
& \text { نخير }
\end{aligned}
$$

• r تا حال از غذاى كه در كنار جاده ها بفروش ميرسد مسموم شدين؟

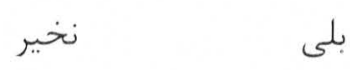$$
\text { اب آيا از حمام هاى شهرى آستفاده ميكنين؟ }
$$ 
نخير

بلى

rrr بيشتر امراض از كدام منبع در شهر كابل بوجود ميايد؟

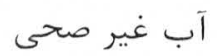

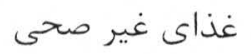

عدم رعايت حفظ الصحه در تشناب

نميدانم

rr منبع اصلى آب نوشيدنى شما جى است؟

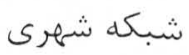

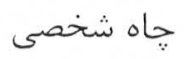

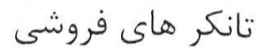

doo

F F إز جه نوع تشناب ها استفاده ميكنيد؟

|نكشاف يافته

غير انكشاف يافته

dos

هيجكدام

rV از جه نوع غذا استفاده مينمايد؟

غذاى خانه

غذاى هوتل ها

غذاى كنار جاده

dos

90 
^ץ هفته جند بار حمام ميكنيد؟

هفته دوبار

هفته سه بار

ojod do

هفته يكبار

qץ از جه نوع حمام استفاده ميكنين؟

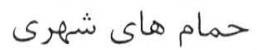

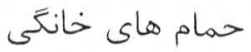

و هر

F. روزانه به جه مقدار آب دسترسى داريد؟

زير • مب ليتر

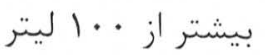

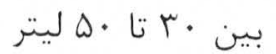

نميدانم

IF. بيشتر از كدام حمام ها استفاده ميكنيد؟

خانَّى

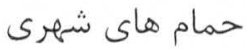

Fا شما زباله هاى تان را در, كجا جمع آورى ميكنيد؟ در زباله هاى روى سرك در سطل هاى كه شاروالى كناشته

در يشت دروازه 
r r آيا زباله ها در ساحه شما با آبهاى سطحى يكجا شده؟

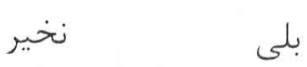
بf

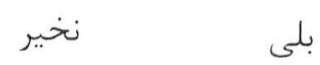




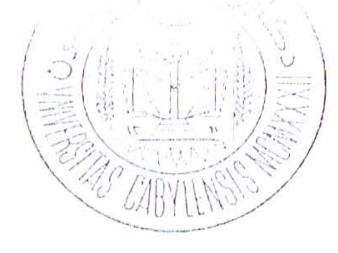

$$
\begin{aligned}
& \text { (a) } \\
& \text { هل }
\end{aligned}
$$

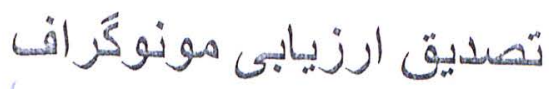

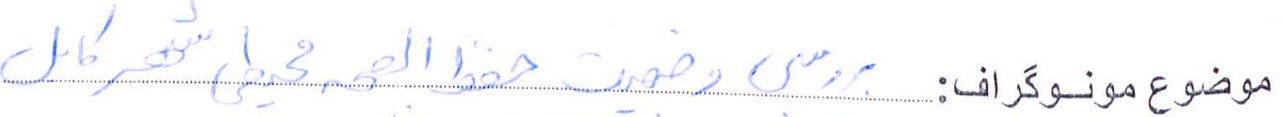

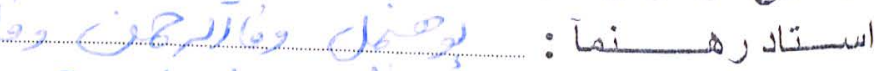

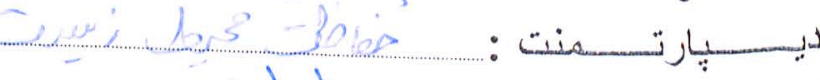

$$
\begin{aligned}
& \text { شهرت تدوين كنتده مونوكر افس : } \\
& \text { ندبر ثبت مونـوكَّ (فن : }
\end{aligned}
$$

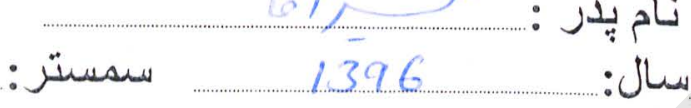

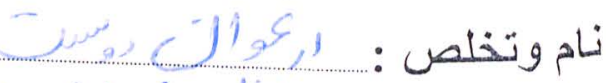

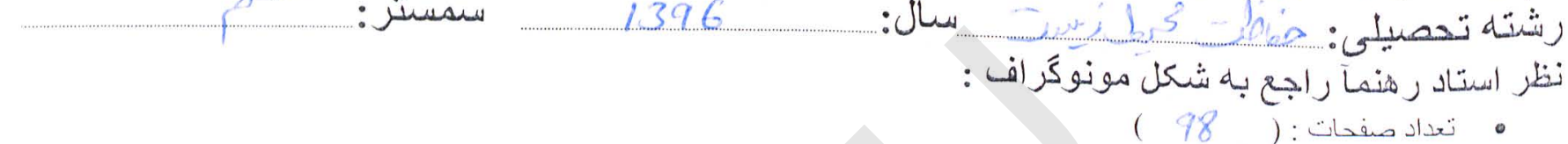
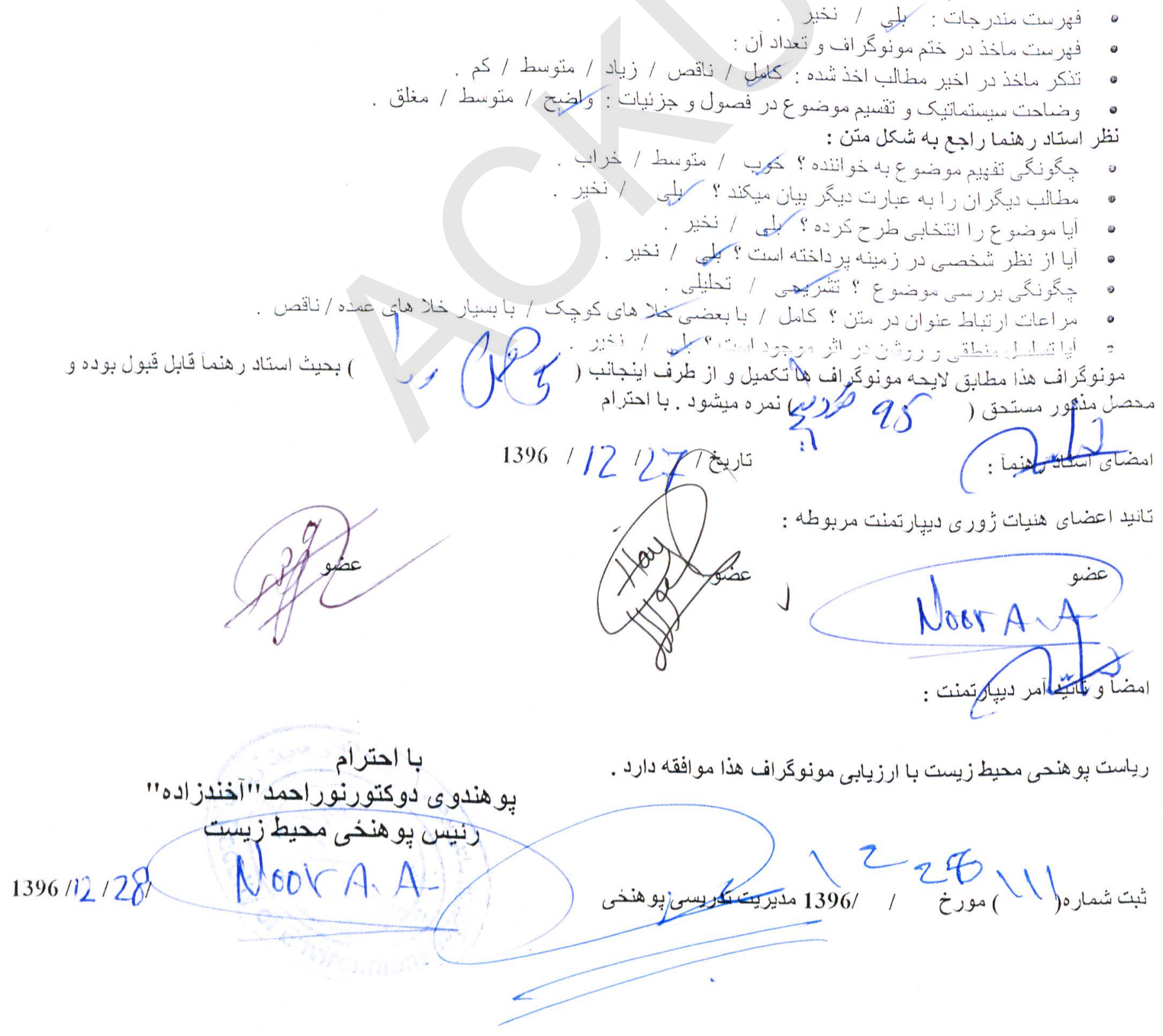